Portland State University

PDXScholar

$1-1-1984$

\title{
Urban housing policy evaluation in the Kingdom of Saudi Arabia
}

Tarek Ali Fadaak

Portland State University

Follow this and additional works at: https://pdxscholar.library.pdx.edu/open_access_etds Let us know how access to this document benefits you.

\section{Recommended Citation}

Fadaak, Tarek Ali, "Urban housing policy evaluation in the Kingdom of Saudi Arabia" (1984). Dissertations and Theses. Paper 852.

https://doi.org/10.15760/etd.852

This Dissertation is brought to you for free and open access. It has been accepted for inclusion in Dissertations and Theses by an authorized administrator of PDXScholar. Please contact us if we can make this document more accessible: pdxscholar@pdx.edu. 


\title{
URBAN HOUSING POLICY EVALUATION IN THE KINGDOM OF SAUDI ARABIA
}

\author{
by \\ Tarek A1i Fadaak
}

\begin{abstract}
A dissertation submitted in partial fulfillment of the requirements for the degree of
DOCTOR OF PHILOSOPHY in
URBAN STUDIES

Portland State University

(C) 1984 Tarek Ali Fadaak 
TO THE OFFICE OF GRADUATE STUDIES AND RESEARCH:

The members of the Committee approve the dissertation of Tarek Ali Fadaak presented May 10, 1984.
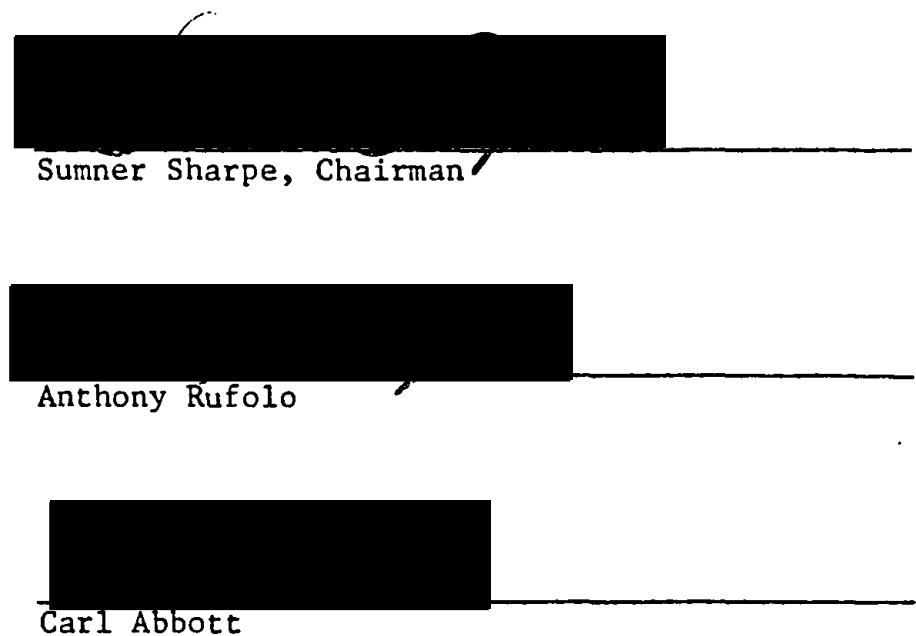

APPROVED :
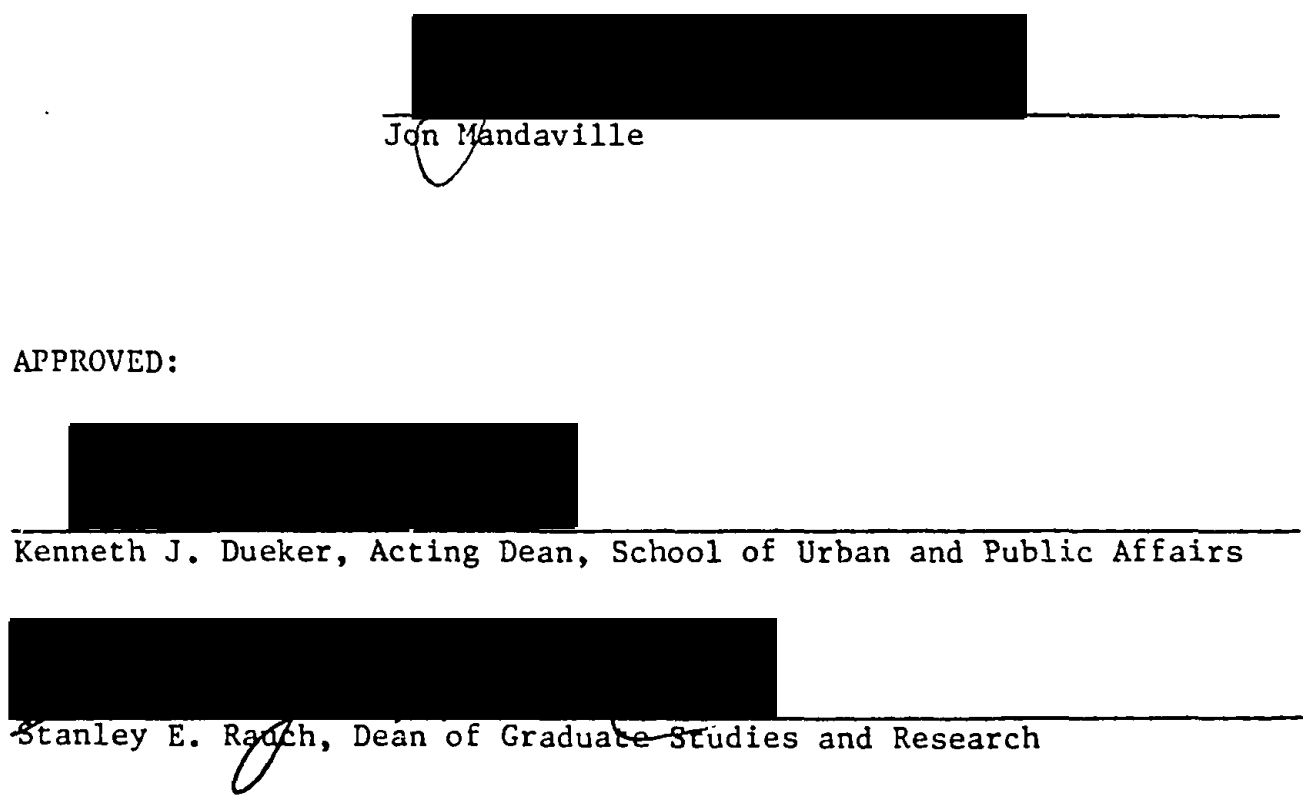
AN ABSTRACT OF THE DISSERTATION of Tarek Ali Fadaak for the Doctor of Philosophy in Urban Studies presented May 10, 1984 .

Title: Urban Housing Policy Evaluation in the Kingdom of Saudi Arabia.

APPROVED BY MEMBERS OF THE DISSERTATION COMMITTEE:
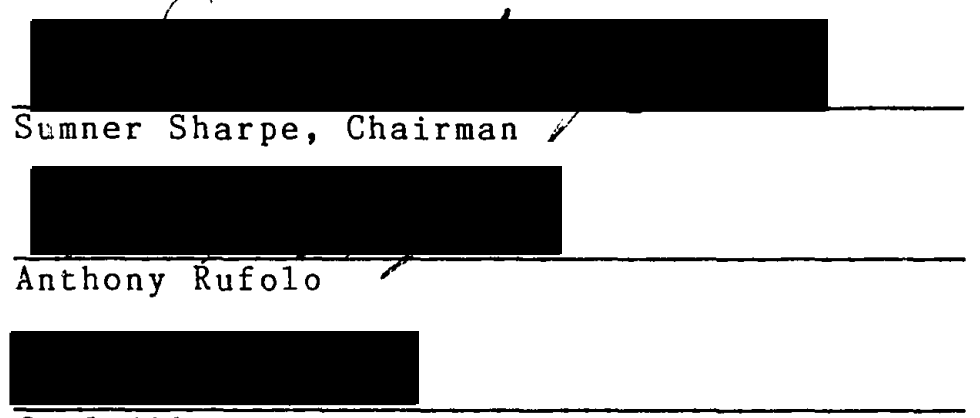

Carl Abbott

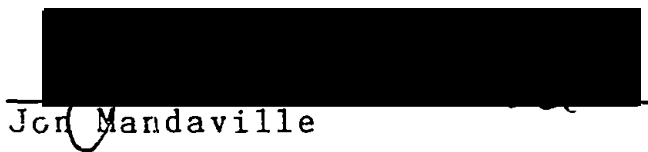

The rise in wealth for the Kingdom of Saudi Arabia led to an increase in demand for more and better housing. In response to this rising demand, and as part of an overall development policy, a housing zoal and several housing objectives were identified. To attain the goal and objectives, a formal housing policy was designed and authorized. It involved direct and indirect assistance to the private sector, a subsidized financing program for new 
housing construction, a serviced land program for the low income, and public housing.

This thesis is an evaluation of the urban housing policy in the Kingdom of Saudi Arabia. Two bases of evaluation are utilized. The first is the Kingdom's own espoused housing objectives. The second involves developing a theoretical framework which addresses the rationales behind housing policy.

The required information was collected from official government documents. Interviews were conducted in the Kingdom to gather additional and unpublished information. Additionally, field visits to housing projects were conducted in the cities of Jeddah and Riyadh. Where information for the Kingdom as a whole was unavailable, data for the city of Jeddah was utilized.

The policy results of the evaluation show that public sector involvement in housing is most effective when indirectly applied. That is, subsidies to the private sector and to purchasers of housing through finance subsidies were more successful in providing housing units than direct involvement through public housing. An important consequence of the difference in effectiveness between privately and publicly built housing is that poor households were deprived of housing benefits.

Recommendations for future housing policy include the provision of housing benefits to the poor, either through 
the existing, but uninhabited public housing units, or through earmarked transfers, or a combination of both. It is also recommended that the existing and future status of public housing be realisticaily evaluated. Finally, it is recommended that the range of financing activities be expanded and that the private sector assistance policies be continued. 
for my Father 


\section{ACKNOWLEDGEMENTS}

The author wishes to express his sincere appreciation to his supervisory committee, particularly Professor Sumer Sharpe, for their valuable advice and help throughout the study and during the course of his doctoral education.

Special gratitude is also due to Dr. M. Safar, Deputy Minister of Higher Education; His Excellency, Mr. A. Al Dirhally, Ministry of Planning; Engineer Mohsen Baroom, Ministry of Housing; the Facult; of the School of Environmental Design, King Abdul Aziz University, particularly Dr. Farouk Mofti, Dr. Tarek Dourani, and Dr. A. Al Daghistani. Mr. G. Abdul Jawad, Saudi Investment Co.; Mr. A. Bokharti, Sert Jackson International; and Dr. Montazar Hakeem were very kind in providing valuable information. Other generous and loyal friends, both in the United States and in Saudi Arabia, provided instrumental help. Special encouragement was provided by Mr. John Bates and very valuable information was made possible through the efforts of Mr. Ali Al Ghandi and Mr. Tarek Al Bassam.

Particular acknowledgement is made to my wife and to my father, whose encouragement and patience were crucial to the completion of the thesis.

Last, but not least, the author's special thanks are to Barbara Dixon, whose friendship and typing efficiency were indispensible. 
TABLE OF CONTENTS

PAGE

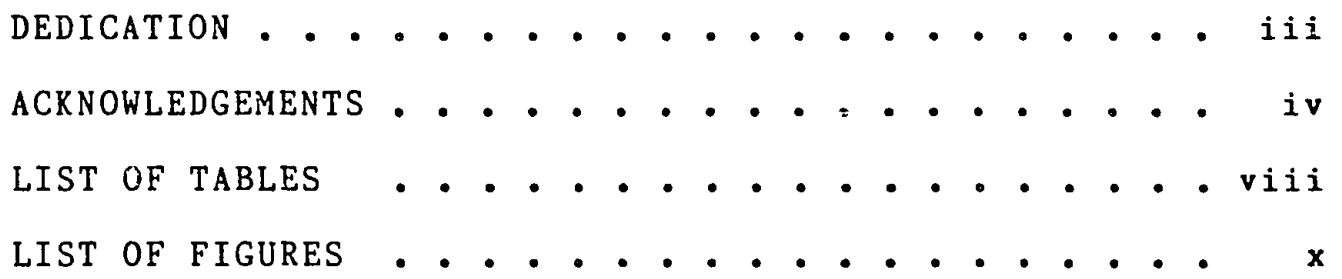

CHAPTER

I INTRODUCTION AND REVIEW OF THE PROBLEM • - 1

Introduction . . . . . . . . . 1

The Problem ............ 4

II A REVIEW OF HOUSING POLICY RATIONALES AND

STRATEGIES • • • • • • • • • • • • 9

Introduction . . . . . . . . . 9

Literature Review of Rationales . . . 9

Equity

Internal Benefits

External Benefits

Spatial Effects

Microeconomic Effects

Efficiency

Housing Policy Strategies . . . . .

Demand Support

General Income Maintenance

Earmarked Grants

Supply Support

Minimum Standards

Filtering 
II (Continued)

$$
\begin{aligned}
& \text { Public Housing } \\
& \text { Rent Control }
\end{aligned}
$$$$
\text { Toward an Applicable Theory . . . . } 51
$$$$
\text { Universal Applicability . . . . . } 51
$$$$
\text { Summary and Discussion . . . . . . } 56
$$

III THE SAUDI ARABIAN POLICY SETTING • • • • • 58

Introduction . . . . . . . . . 58

Policy Determinants . . . . . . . 58

A Normative Framework

The Islamic Welfare State

The Development Environment

The First Five-Year Development Plan • 65

The Second Five-Year Plan . . . . 66

The Third Five-Year Development Plan • 66

The Housing Sector . . . . . . . 69

Demographic Changes

Housing Types and Condition

Housing Sector Problems

Land

Labor

Materials

Capita 1

Summary •. . . . . . . . . 90

IV THE SAUDI ARABIAN HOUSING POLICY . . • • 91

Introduction . . . . . . . . 91

The Housing Policy Elements . . . . 91

The Goal

The Objectives

The Criteria 
IV (Continued)

Housing Achievements . . . . . . . 97

Public Housing

Finance

The Saudi Real Estate Company

Building Material Aids

Labor Aids

Rent Control

Institutional Response

Housing for the Poor

Housing Through Charitable Institutions/ Individuals

The Prince Fawaz Cooperative Housing Project

Housing Policy for the 1980s . . . . 128

Sumary and Discussion . . . . . . 132

V

HOUSING POLICY EVALUATION • • • • • 139

Introduction . . . . . . . . . 139

Evaluation Based on Objectives... 139

Evaluation Based on Theoretical

Framework .... . . . 149

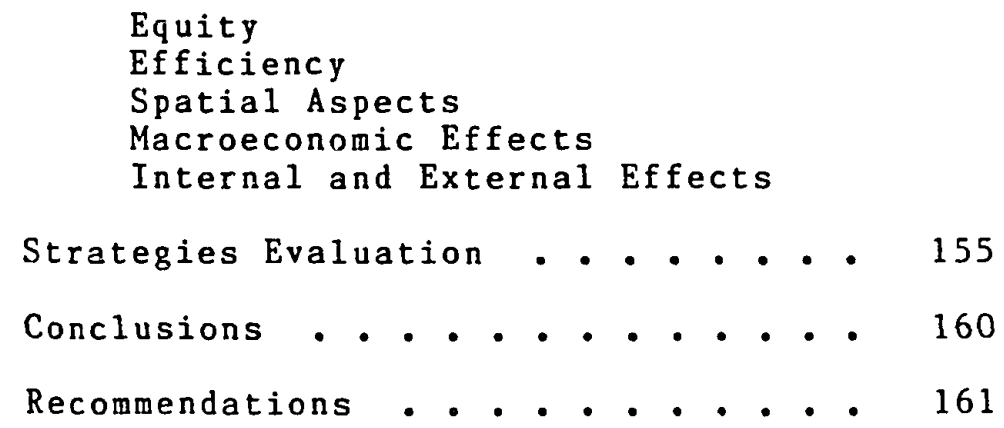

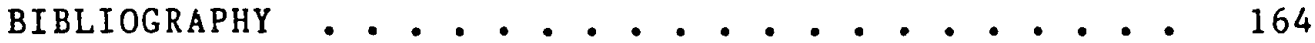




\section{LIST OF TABLES}

I Review of Major Categories Dealing with

Housing Effects.......... 15

Illustration of the Prisoner's Dilemma •. 28

II Cost of Living Changes Kingdomwide 1970-80 . 70

IV Gross Domestic Investment and Gross

Domestic Product, 1970-80 . . . . . 71

$V \quad$ Income Distribution by Household, Jeddah . . 72

VI Monthly Family Income in Riyals by

Nationality, jeddah . . . . . . 76

VII Distribution of Dwellings by Type in

Jeddah, 1978 . . . . . . . 77

VIII Age of Dwellings in Jeddah . . . . . . . 77

IX Condition of Dwellings in Jeddah . . . . 78

$X \quad$ Tenure in Jeddah, 1971 versus 1978 . . . 79

XI Growth of the City of Jeddah . . . . . 81

XII Residence Permits Issued to Foreigners,

Kingdomwide . . . . . . . . 83

XIII Growth Rate of Main Building Material

Imports, Kingdomwide, 1969-1984 . . . 85

XIV Loan Growth Rate, Kingdomwide . . . . . 89

XV Estimated Housing iveed and Supply, 1975-80 . 93 
YVI Public Holsing Project Summary • • • • • • 98

XVII REDF Capital and Investment Loan Growth • . 108

XVIII REDF Private Loan Disbursements . . . . . 108

XIX Saudi Industrial Fund Activities in

Building Materials. . . . . . . . 116

XX Construction Cost Index and Building

Permits Kingdomwide . . . . . . . . 120

XXI Planned Housing Supply Estimates • • • • • $\quad 131$

XXII Housing Policy Objectives and Achievements . 140 


\section{LIST OF FIGURES}

FIGURE

PAGE

1. A Suggested Causal Chain Illustrating

Housing Effects............ 17

2. Strategies of Housing Support . . . . . 43

3. Crude Oil Production, 1970-80 ...... 64

4. Government Revenues and Expenditures

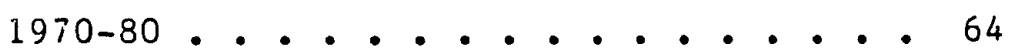

5. The Abandoned "Candilis" Project, Jeddah . 100

6. The Jeddah Rush Housing Project . . . . 103

7. The Dammam Rush Housing Project... . . 103

8. The General Ilousing Project, Jeddah . . . 105

9. The Bin Mahfolz Endowment (Roubat), Jeddah . 130

10. The Al Khounji Al Sagheer Endowment

(Roubat), Jeddah ........ 129

11. Prince Fawaz Cooperative Housing Project . . 130 


\section{CHAPTER I}

\section{INTRODUCTION AND REVIEW OF THE PROBLEM}

\section{Introduction}

As the world oil situation changed during the decade of the 1970s, the Kingdom of Saudi Arabia experienced a tremendous increase in wealth. In 1970, the Kingdom was producing approximately 1.32 million barrels of crude oil per day valued at $\$ 1.80$, yielding total revenues of $\$ 334$ million annual1y. In 1980, the corresponding figures were approximately nine million barrels per day valued at over $\$ 30$ per barrel and yielding approximately $\$ 60,000$ million annually. (Ministry of Planning, 1980)*

During the period from 1970 to 1983, this tremendous increase in wealth created a large increase in the demand for urban housing, which is attributable to the following general reasons:

(1) A migration of foreign labor to supplement the

* A1 the figures above are approximate because not all of the oil revenues were received by the Kingdom. Price and quantity also vary over a given year so end of year figures were used. 
resident work force in executing very ambitious development projects.

(2) An increase in migration toward the major metropolitan centers from within the country.

(3) An increase in the expected value of housing as an investment, given the large appreciation of real estate values in general. This was further enhanced by the rather limited indigenous investment opportunities extant at the time.

(4) A rise in housing quality expectations as the standard of living and incomes increased due to the economic changes.

The government of the Kingdom initiated comprehensive development plans which included a housing policy directed at achieving numerical and qualitative objestives to be executed for the most part by the private sector, but with government assistance.

This dissertation attempts to evaluate the Saudi Arabian urban housing policy by investigating the basis of that policy, primarily the rationales that guide housing investment. Another important item in this analysis of the Kingdon's housing policy is an evaluation of the strategies by which housing policy is implemented.

The definition of housing to be used throughout this study shall not be restricted to dwelling units. llousing shall be viewed as a complex of legal, social, economic, 
and political features of a society that determine number, size, quality, geographic distribution, environment, and allocation of dwelling structures (Nevitt, 1980). Housing policy shali be viewed as embracing issues such as government expenditures, loans and loan guarantees for investments, zoning regulations and building codes, and legal provisions of property rights (Aaron, 1972).

This thesis shall address urban housing only. This is not to suggest that rural housing is in any way less important, but rather that information availability and the already broad nature of the topic necessitate restricting the scope to housing within the urban setting.

The remainder of this chapter shall explore the Kingdom's housing policy in general. It shall outline also the nature of the problem and the significance of the evaluation. Chapter II will attempt to cover the general literature pertaining to the general rationales underlying housing policies as well as general strategies to implement those policies. The rationales have been, for the most part, developed for western societies with a specific focus on the United States, an important consideration setting the context for discussing Saudi Arabian policy. Chapter III provides an overview of the Saudi policy setting both in terms of broad development goals and objectives and in terms of specific housing sector problems. Chapter IV discusses the scope and 
outcomes of Saudi Arabian housing policy; and Chapter V evaluates and analyzes that policy and provides general conclusions and recommendations specific to the Kingdom.

The Problem

Several housing sector problems emerged during the early stages of the accelerated deveiopment programs of the 1970s. As recently as 1975, the following problems existed (IIUD 1977; Ministry of Planning Reports, 1975, 1980; Kadi, 1980):

(1) Resources for planning, building, and maintaining housing were in short supply and land speculation was rampant;

(2) Technologies for increasing worker output had not been applied, nor had construction management skills been developed to avoid costly delays;

(3) Labor prices dramatically increased, reflecting shortages of indigenous skilled human resources;

(4) Capital for residential construction was availatle primarily through lifetime savings. There existed no long-term mortgage lending and secondary mortgage system. This generally reduced the purchasing power of many households.

To meet the growing demand, and to tackle the above problems, the government initiated several directives which 
may be considered as the backbone of housing policy in the Kingdom .

(1) Preparation of the "General Housing Project," which projected 34,269 public housing units to be built in nine urban areas; (Started in 1978.)

(2) Execution of the "Rush Housing Projects," consisting of 4,752 public housing units to be built in the three major metropolitan areas of Jeddah, Riyadh, and Dammam "as soon as possible;" (Started in 1977.)

(3) Formation of the Real Estate Development Fund (REDF)--a government finance agency designed to provide interest free loans for the construction of new housing units for Saudi Arabian citizens; (Started in 1975.)

(4) Expansion of a land grant program administered by local governments for eligible low income citizens;

(5) The facilitation of building material availability in local markets as well as price subsidies for some building materials;

(6) Formation of the "Saudi Real Estate Company," a private corporation aided by the government upon its founding, in 1976, to execute real estate projects within the Ringdom.

The second five-year plan (1975-80) projected the 
construction of 267,000 units--68 percent of which were to be built by the private sector and 32 percent by the public sector* To achieve this goal, the government relied on the directives listed above.

It should be noted that the above directives were both supply and demand oriented. Supply support policies generally subsidize housing production or rehabilitation. These are manifested in the directives above, except (3) and (4). Demand support policies subsidize consumption of housing through purchasing power stimulation. These are manifested in directives ( 3 ) and (4).

Specific problems resulting from Saudi housing policy can be sumarized in the following:

(1) Public housing projects cost more per unit than privately constructed units;

(2) None of the 4,752 public housing "Rush" units that have been completed are inhabited;

(3) The scope of the existing home financing system is narrow. Outside of the Real Estate Development Fund, which grants interest-free 25 year loans of up to 300,000 riyals per household for new housing, there are no institutions to handle long-term finance;**

* No quantitative housing objectives were identified in the first five year plan.

**0ne riyal is approximately $\$ 0.30$. 
(4) The "Saudi Arabian Real Estate Company," which was formed with government assistance, but is a private sector organization, has had a limited role geographically even though its activities have been profitable, i.e., its activities have been primarily confined to the capital city of Riyadh.

(5) The land grant program did not perform up to expectation, especially where low income citizens were concerned. Specifically, continual delays in the preparation and distribution of sites have occurred.

The above do not necessarily imply that public involvement in housing has been a total failure, but rather demonstrate the need to understand the basis for housing policy (the rationales) as well as the process by which objectives are realized (the form of policy).

The analysis will utilize the following approach: First, general rationales of public involvement in housing will be identified. These rationales typically involve the intrinsic and extrinsic effects of housing on people, such as efficiency in building and purchasing homes, spatial aspects, macroeconomic stimulation, and equity issues. These provide a broad basis to evaluate policy. A narrower policy evaluation basis utilizes the Kingdom's own housing goals and objectives. General strategies for housing 
support, as identified earlier, will be reviewed and utilized in the evaluation.

No known studies address overall Saudi housing policy except for Kanoo (1971), who dealt with general house construction systems and architecture in Saudi Arabia and the Gulf States.

Finally, the transliteration system used in this thesis followed the Library of Congress Arabic transliteration system (U.S. Library of Congress, 1945) except for reference names and titles, which were directly copied as written in the sources. 
CHAPTER II

A REVIEW OF HOUSING POLICY RATIONALES AND STRÁTEGIES

Introduction

\begin{abstract}
This chapter attempts to lay a foundation for evaluating Saudi housing policy. First it addresses the theoretical basis for government involvement with housing, which will then be used to question the existence of a "universally" applicable set of rationales to guide housing policy in general. Second, it includes a review of strategies available to implement housing policy goals. A distinction shall be made between demand support and supply support strategies where the former implies assistance in the consumption of housing, whereas the latter involves assistance in the production and/or rehabilitation of housing .
\end{abstract}

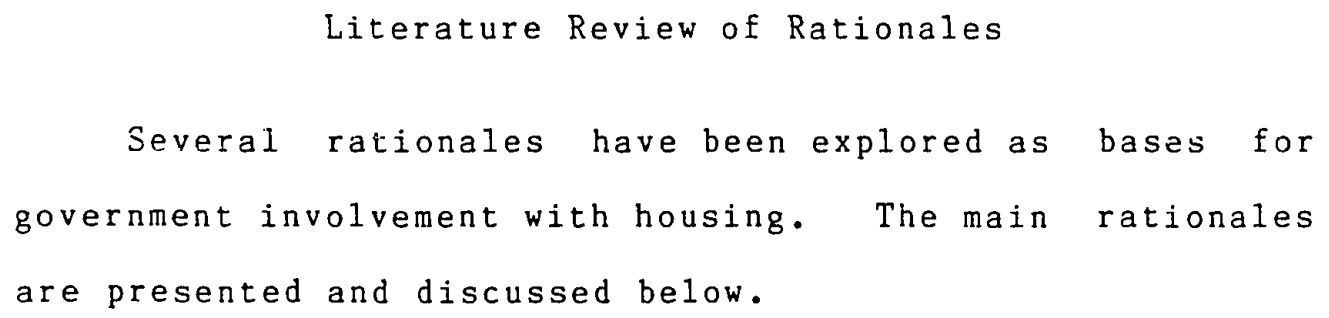


$\underline{\text { Equity }}$

In the definition of housing utilized for this thesis, the allocation of dwellings is a central feature. A basic rationale is the existence of a "fair distribution of adequate housing" for a given population. The concept of fairness in distribution is not restricted to housing, but embraces a broad scope of services including food, clothing, medical care, education, etc. Even though it may be more efficient to have a welfare program providing cash rather than in-kind transfers, the latter type of transfer may be more politically and economically appropriate. Musgrave (1976) suggests that public concern with housing is based upon society's evaluation of housing expenditures as being "meritorious," ice., expenditures on so-called "merit" goods are viewed as being more valuable than others which consumers themselves would choose. Nierit goods are not necessarily restricted to housing, but include goods considered to be social needs, e.g. food, medical care, education, etc.

The notion of benevolent welfare interdependence was formalized by Mishan (1981) to be as follows: $u^{1}=f\left(X^{i}\right.$, $\left.X^{j}, \ldots, D\right)$ where $u^{i}$ represents the total utility of welfare of the ith individual being a function of that individual's consumption of a given good $x^{i}$ as well as another person $j$ consumption of the same good $x^{j}$ and finally, the distributional structure of money income in society, $D$. 
Given that a person's welfare is assumed to depend upon specific goods consumed by others, market prices do not necessarily insure that exchange optimum is insured; or alternatively stated, people's freedom to buy goods at market prices is not the most efficient state of affairs under the condition of welfare interdependence. Because bargaining costs do exist, it may be costly to negotiate consumption levels of specific "merit" goods between givers and receivers if cash transfers are used to redistribute income. For example, how are givers to be assured that their donations will be spent on better housing--a "merit" good, rather than wine--a non-merit good? Additionally, donors may give out less in cash if the goods to be distributed are not specified; and consequently, recipients who prefer cash transfers may be better off receiving inkind transfers because they would be worth more than the smaller amounts of donated cash.

The point is that cash transiers are not necessarily the best redistributive tool in terms of welfare maximization, given the condition of welfare interdependence.

From a political viewpoint, in-kind transfers are more acceptable as redistributive tools to correct social and economic inequalitics primarily because of their visibility, the ability to control or adjust these transfers, and the ability to focus transfers on merit 
goods. The classification of housing as a merit good, by itself, implies that investments in housing are expected to bring about intrinsic or internal benefits such as better physical and mental health.

\section{Internal Benefits}

The internal benefits of housing or its benefits regarding mental and physical health appear to be more intuitively acceptable rather than empirically provable.

Kas1 (1976) reviewed one hundred and seventy-eight multidisciplinary studies dealing with the empirical findings regarding the effects of various physical parameters of housing and the residential environment on behavior and on mental and physical health. The domain reviewed by Kasl, who is an epidemiologist, include sociological, social psychological, psychiatric, socialmedical, gerontological, public health, architectural, and urban planning empirical works on the subject. Table I represents a summary of the major categories that Kasl reviewed along with the predominant research designs. His major findings are:

(1) There is a link between parameters of housing-such as space, comfort, etc.--and satisfaction. Satisfaction, however, is likely to be sensitive to a household's adaptation to housing. it ina be viewed as an outcome variable, as part of 
mental health, rather than an intermediate variable affecting health as was assumed by some of the studies.

(2) Social interaction appears to have a strong link with housing parameters. Substandard housing was shown to be not mutually exclusive of the existence of rich social networks, adequate social interaction, and mutual help. Kasl's review of rehousing studies indicate that the disruption of these social networks may be a disbenefit and shouid be included when evaluating possible benefits of improved housing due to relocation. Social interaction may be viewed also as an outcome variable.

(3) Kasl emphasized that even though certain relationships do involve simple causal mechanisms (e.g. presence of rodents and rodent bites, presence of lead paint and probability of lead poisoning in young children, etc.) a relationship between housing parameters and chronic conditions was not firmly established in the extensive literature reviewed, primarily because associations between housing and health appear to operate via social variables.

(4) Kasl's major conclusion is that there is probably a very significant effect of housing on health 
and behavior, but that the effect is very complex and mediated by social and physiological processes of reaction, adaptation, and accommodation to the housing environment.

It should be noted that Kasl's study apparently did not review international cases in any of the six broad categories except for several British studies that dealt with relocation effects. The relevance of international comparisons is illustrated in the causal chart (Figure 1).

The conditioning variables, which are demographic, cultural, and personality oriented, affect the process by which housing affects health. International differences are likely to affect the cultural conditioning variables and thus have a likely effect on the proposed causal chain. The cultural element plays an important role, influencing the social-psychological variables which interact with the physical aspects of the housing environment. Yet, Kasl's very comprehensive review does have a weakness: it does not include an intercultural comparison of the effects of housing on health, even though one of his major points was that, "...in the long run, the major point to emphasize is that no jutervention which involves housing can ever afford to neglect the social matrix within which housing is firmly imbedded" (Kasl, 1977, p. 299). 
TABLE I

REVIEW OF MAJOR CATEGORIES DEALING WITH HOUSING EFFECTS*

CATEGORY

DESIGNS

Surveys, cross

sectional design

and neighbor

hood

2. Urban ecology

Isolates different characteristics of census tracts by pathological basis lobtained through agency frequency data)

3. Various parameters of housing and its environment Igeneral dealing with slums and new housing developments)

4. Voluntary housing
Investigates social interaction among relatives, different studies done on children, the elder $1 Y$, and "non-homogeneous" populations

Longitudinal studies looked at pre and post move effects on an experimental and a control group

(those who did not move
FINDINGS AND COMMENTS

- Satisfaction with housing mainly related to space. Mediated by social class and strongest with lower social groups. - Nature of dwelling more important than location except for elderly and upper social classes.

- Overcrowding, poor housing, and general disorganization (percentage of people living alone, etc.) correlated with higher rates of tuberculosis, disability, venereal diseases, infant mortality, and psychosis.

Claims put forth that urban ecology indicates geographical concentration of a certain pathology. Too many "intervening" poverty variables (e.g. race, education, income, work status, age, family structure, etc.) exist and introduce confounding and spurious errors into the data analysis and interpretation.

- Among relatives and existing friends, physical proximity and social homogeneity are important. A relevant dimension of housing is "functional distance," i.e. contact between neighbors. For older people, proximity to neighbors and facilities are more important than for other groups. Studies dealing with children found that crowding was a relevant variable when controlling for social class and race. Kasl claims that weak relationships between housing and outcome variables (health) are primarily due to intervening variables.

Consequences of rehousing were primarily related to housing satisfaction and positive neighborhood perceptions, but no effects on mental health or well being resulted. Even though some results indicated that rehoused groups were a little healthier than the control groups, the benefits did have a selective age group--children (Wilner 1962). Medical studies cited indicate that relocation, being a major life change, can be stressful and can have definite health consequences. 
TABLE I (continued)

5. Involuntary relucation

Institution-

alization and

enfurced

changes due

to urban

newal, high-

way corstruc-

tion, etc.

6. Environmental psychology
Cross sectional designs and long i tudinal

ones
- Longitudinal studies of the effect of institutional transfer of the elderly, i.e. moving from one institution to another, revealed increases in mortality even though those relocations involved housing comparable to or better than the previous institutional one. Cross sectional studies were claimed as not sufficiently accounting for spurious and confounding effects such as self selection, anticipation, etc. Relocation due to urban and highway construction revealed that relocated slum dwellers generally pay higher rents without necessarily experiencing better housing. Grief reactions or poor adjustments were more likely among less educated and lower occupational status. Finally, it is the elderly who appear to be the most vulnerable to negative effects of relocation primarily due to previous (pre-relocation), extensive friendship ties and the conveniınce to many facilities.

- Kasl cliams that contributions of this field to the relevance of mentil and physical health effects is limited and disappointing. 'This is primarily due to the lack of generality of the studies as well as to their focus on short term effects.
Focus on micro aspects, i.e. short range interaction/ response between man and built environment 


\begin{tabular}{|c|c|c|c|c|}
\hline $\begin{array}{l}\text { OBJECTIVE } \\
\text { ENVIRONMENT }\end{array}$ & $\begin{array}{l}\text { PERCEIVED } \\
\text { ENVIRONMENT }\end{array}$ & $\begin{array}{l}\text { PROXIMATE } \\
\text { RELATIONS }\end{array}$ & $\begin{array}{l}\text { MEDIATING } \\
\text { PROCESS }\end{array}$ & $\begin{array}{l}\text { OUTCOME } \\
\text { VARIABLE }\end{array}$ \\
\hline $\begin{array}{l}\text { Physical } \\
\text { attributes } \\
\text { of housing } \\
\text { unit }\end{array}$ & $\begin{array}{l}\text { Perceptions } \\
\text { of privacy, } \\
\text { noise, pol- } \\
\text { lution, etc. }\end{array}$ & $\begin{array}{l}\text { Adaptations, } \\
\text { variation } \\
\text { in use of } \\
\text { space }\end{array}$ & $\begin{array}{l}\text { Anemia, } \\
\text { tension, } \\
\text { blood } \\
\text { pressure }\end{array}$ & Diseases \\
\hline
\end{tabular}

Influenced by the conditioning variables:

\begin{tabular}{|lcc|}
\hline DEMOGRAPHIC & CULTURAL-SUBCULTURAL & PERSONALITY \\
\hline Age-Sex- & (Religion/Religiositg, & Coping stgIes, \\
Income, etc.) & Ethnic, etc. & needs, etc. \\
\hline
\end{tabular}

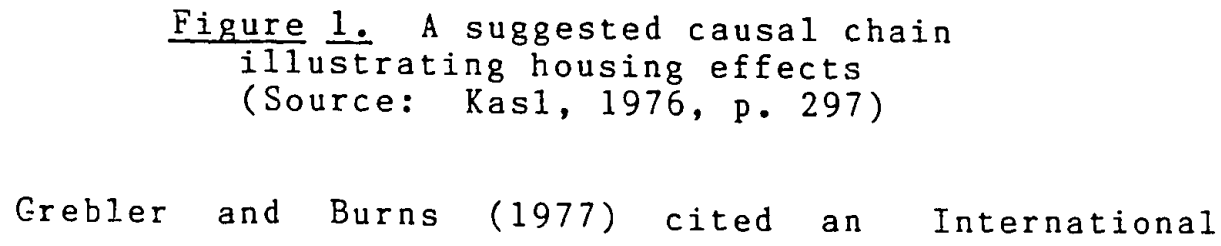

Housing Productivity Study (I.H.P.S.) based on case studies of housing improvement in some less developed countries (LDCs) and less developed regions of the United States. The study was conducted by a team from the University of California in the 1970s. Its principal hypothesis was that better housing can generate the following benefits: an increase in work productivity, higher levels of health, an increase in productivity (or effectiveness) of education, and finally, a lowered incidence of social deviance. The design was longitudinal (time series) involving an experimental and a control group for seven cases located in 
Korea (1), Venezuela (1), Mexico (2), and the U.S.(3). Data was collected by survey, involving information on productivity from compang/employment records, health records, health information from clinical records, and social deviance information from police records. Data on school attendance was also included. All sites experienced housing improvements due to rehousing.

The empirical findings were ambiguous. Increased work productivity resulted in only two of the four measured cases. Only one out of four cases studied showed improvements in school attendance due to housing. Only one case regarding deviant behavior was studied and it showed a positive effect, i.e., less deviance was reported.*

Unlike some findings mentioned by Kasl, no changes were in the "wrong direction," i.e., in no cases did better housing yield worsened conditions for the rehoused. However, the outcomes do not strengthen the fragile empirical linkages between better housing and health. Several issues could have caused the ambiguities--in addition to the unavalability of data--such as (Grebler and Burns, 1977, p. 163):

(1) Substantial lags could be involved before housing improvement effects become evident;

(2) Ambiguities may have been due to changes in

* Benefits due to housing were not estimated for all the sites due to data limitations. 
densities of the residences, e.g. higher densities may imply a spread of communicable diseases and/or greater feelings of alienation for those rehoused. The issue of densities and crowding shall be addressed below.

Fischer et al (1975) conducted an extensive review to evaluate current research on the effects of crowding. Their findings indicate that responses to crowding vary with expectations, functional use of space or design, social situation, and culture. A study by Mitchell (1971) was cited on crowding effects in Hong Kong. It was concluded that density, by itself, didn't have much of an effect. Additionally, Newman (1972) in his classical study of "defensible space" concludes that building height and type correlate more strongly with crime than does density. Problems with the density studies reviewed by Fischer et al (1975) include, among others, multicollinearity, difficulties in making in-situ comparisons on the effects of density, and determining the direction of causal arrows, i.e. experimental as well as conceptual problems were cited.* Some of the problems with theory included "weak" linkages made between density at the personal versus the commity levels. Additionally, an argument similar to that put forth by Kas1 (1976)--as reviewed earlier--was

\footnotetext{
* Fischer reviewed over eighty studies dealing with density and crowding.
} 
by Fischer et al and stressed the view that density probably does have an effect which is important, but has not been substantiated due to the weak evidence thus far. Demographic and cultural elements may be more pivotal in explaining impacts on people.

Finally, Schorr (1966) also conducted a very extensive overview of the effects of housing. He identified and reviewed three types of evidence: first, personal or case observation by testimony of slum dwellers or those who know them or worked with them; second, correlation studies performed by various academicians from various fields; and third, comparisons of people in different types of housing regarding behavior and attitudes. Schorr's conclusion regarding the issue is that, "...The type of housing occupied influences health, behavior, and attitude, particularly if the housing is desparately inadequate...dilapidated, or lacks a major facility." (1966, p. 31) However, Schorr also notes that over and above family influences, other influences of adequate housing are not empirically certain, but lack of evidence is not to be equated with negative evidence.

It thus appears that a theoretical case for housing subsidies cannot rest on arguments of pathological outcomes of ponr housing by itself given the above reviews, but at the same time the effects of poor housing cannot be discounted. 
Externa1 Benefits

In evaluating the notion that subsidized housing will have spillover effects into the surrounding neighborhoods and beyond, the following studies were reviewed.*

Varaday (1982) conducted a social science literature review of studies dealing with neighborhood spillover benefits, specifically, reductions in incidences of crime and disease, fire hazards, and increases in property values. Additionally, citywide and societal benefits were also reviewed, i.e., reduced governmental costs, reduced racial and economic segregation, increased overall productivity: and econnic stimulation. He dealt with studies from different disciplines--some of which were reviewed earlier (Kas1, 1976; Grebler and Burns, 1977; Fischer et al, 1975). These studies primarily addressed reductions in the incidence of crime and disease due to good housing. Their research results were mixed, i.e., the evidence was inconclusive.

Another spillover effect is the increase in desirability of an area. This is likely to be reflected in increases in property values of adjacent properties due to housing investments. This operates by reducing the uncertainty to invest in a given area due to brighter prospects that seem possible. It could affect potential

*The spillover effects are those that go beyond the direct user of housing. 
direct investors, the landlords, or the financial intermediaries whose outlouk could further stimulate demand. Varaday concluded that the support for the hypothesis related to external benefits of housing is weak, especially where these benefits were to be lised for justifying new housing, even though empirical evidence might support the view that housing subsidies would reduce fire fighting expenditures. Ic was not viewed as enough to warrant a new public housing program, but rather to make a case for the establishment and enforcement of "reasonable" housing codes.

Nourse (1976) identified the ideal building code standard as one that improved quality to a level where additional costs of quality improvement are exactly equal to additional benefits accruing to society. These levels would be difficult to identify since the additional gains in benefits to the community would be difficult to identify and express in monetary units. The codes apparently do have a positive effect in that they improve the quality of housing. Nourse believed that building codes go beyond preventing epidemics and fires. However, subsidizing the poor in standard quality housing with the reasoning that surrounding property values will be improved does not have sufficient evidence. Furthermore, building codes appear to go beyond preventing epidemics and fire dangers. They also increase housing costs. 
The National Commission on Urban Problems (1968) conducted a review of the allegations that the plethora of building codes add to housing costs, delay construction, inhibit creative design, have provisions which are outdated, and are dominated by a very smali group in the industry, among other problems. Upon conducting a survey (as well as a program of hearings, meetings, interviews, etc.) involving approximately 18,000 units of local government, the Commission found that the allegations were true and that major technical and political change was needed.

To maintain restrictive codes, a subsidy would be required to enable poorer households to afford some minimum standard of living. This concept is directly related to the "merit good" aspects of housing introduced in the beginning of this chapter.

Rothenberg (1976) basically followed Nourse's argument. He used the inverse to illustrate positive externalities, i.e., his argument discussed the negative effects resulting from poor or inadequate housing. The areas discussed by Rothenberg were basically those discussed above: fire hazards, illness, crime, and psgchological and social adjustment problems. The conclusions drawn from the studies imply that empirical evidence is difficult to achieve, but the hypothesis that positive external spillovers occur from good housing was 
not rejected. An implication of the findings is that lowincome slum residents be the focus of housing intervention. Additionally, views of housing should encompass structure, neighborhood, and accessibility .

Two interesting problems regarding external effects were identified by Grebler and Burns (1977) regarding the incidence of benefits from improved housing. The first issue is the temporal distribution, i.e., benefit streams are likely to change over time with the possibility of zero benefits or even disbenefits appearing in the short run followed by benefits.* Disruptions following a move were not unexpected until adjustments to new environments occurred (Schorr, 1966). The temporal distribution of the benefit stream due to improved housing was not explicitly addressed in the cited 1iterature. It may be that its identification and incorporation into the assessment/evaluation studies would clarify the inconclusive evidence.

The second issue is the sectoral distribution of the benefits accruing from housing investments. By this it is meant that health effects from the housing sector may spill over into the health care sector, education benefits into the education sector, etc. If this spillover effect is unaccounted for, the receiving sector(s)--such as above,

* The time factor identifying the short run was not identified. 
education and health--will experience efficiency increases as output increases, but the credit will be undeserved, i.e., education and health will receive output increases due to housing. The relevance of this issue becomes apparent when the rule for optimum resource allocation is reviewed. It occurs where, "...the marginal contribution of housing investment to national income jusi equals the decrease in the alternative sectors resulting from an additional investment in housing." (Grebler and Burns, 1977, p. 163) The implication is that unaccountability for the spillover will probably lead to underinvestment in the housing sector. From a policy standpoint, it would be difficult to disentangle the spillovers occurring among the different sectors which compete for investment within a national economy.

An additional rationale linked to the concept of external effects involves an economic-behavioral model of decisionmaking under uncertainty. Davis and Whinston (1966) introduced the idea that if two neighbors are in an area undergoing deterioration, uncertainty will tend to produce a situation known as the "prisoner's dilemma" where rational behavior by individuals will imply a housing investment level incongruent with the socially optimal 
one.* For example, two homeowners have the choice to both upgrade their dwellings, which would result in a 10 percent return for each. If only one of them upgrades while the other does not, his realized return becomes four percent, which represents a negative external effect of an unimproved neighbor's house. The second neighbor however, gains six percent due to the upgrading, assuming that the second neighbor can gain five percent from investing funds elsewhere. (See Table II.)

Uncertainty and self interest would imply a decline in neighborhood quality given no cooperation between the homeowners, because the individually rational reaction for each is not to invest, since that would gield the highest outcome. However, Mills, (1979) views the condition as too restrictive. There would be no dilemma if neighbors communicated, because they would obviously both choose upgrading.

The "neighborhood effect" could thus be minimized by agreements between property owners regarding property maintenance through private covenants, e.g., Planned Unit Development (PUD) bylaws, etc. It should be noted, however, that the external effects do exist and that transaction costs in making agreements can be high enough

*The model is where two crime suspects are interrogated separately by the D.A. If both confess, both go to jail. If neither confesses, both go free. If one incriminates the other, ( $s$ )he is rewarded. Given the unknown nature of the other's strategy, each will be better off by confessing; both will confess and go to jail! 
to make the dilemma applicable. Even so, government involvement with housing would not be justified to warrant public housing, but rather with measures to reduce housing investment uncertainties and enforce contractual obligations.

Other external effects include blockbusting and abandonment. Bourne (1981) identified the blockbusting practice as a means of securing rights to an area at the lowest possible cost. The process typically involves the purchase of several houses in the areas which are ripe for development and then renting those units to a clientele perceived by the neighborhood to lower the value of the whole area. The new clientele may be perceived, for example, as the "wrong" class or color. This process would lead to flight from the neighborhood and declining land prices, but speculative gains for some owners.

Abandonment refers to housing that has been given up-both legally and actually (Meeks, 1980, p. 86). It can occur even in tight housing markets. Grigsby and Rosenberg (1975) emphasized the following causes of abandonment.

(1) Increases in operating costs;

(2) absentee landlords unwilling and/or unable to maintain the properties;

(3) poor management; and/or 


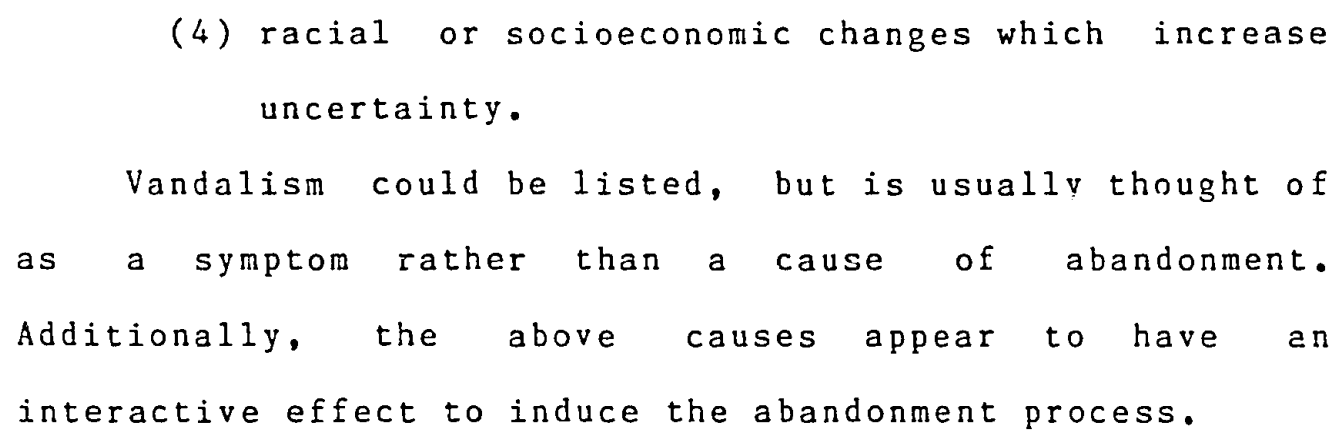

TABLE II

ILLUSTRATION OF THE PRISONER'S DILEMMA

\begin{tabular}{lcc}
\hline Options*** & Gains: & I \\
\hline A. Both invest & $10 \%$ & $10 \%$ \\
B. I Invests, II does not & +4 & $6 *+5 * *$ \\
C. II invests, I does not & $+6 *+5 * *$ & 4 \\
D. Both do not invest & 5 & 5 \\
\hline
\end{tabular}

\footnotetext{
Many of the external effects mentioned above would warrant corrective regulatory approaches such as antidiscrimination and fair housing laws, land use regulations, etc.

Finally, there is an external issue which is seldom addressed in the housing literature, and that is the

* From external effects

* From investing elsewhere

** In the context of the prisoner's dilemma, Option A corresponds to both prisoners not confessing. Options $B$ and $C$, one confesses the other does not; and in $D$ both prisoners confess.
} 
political effect. From a political perspective, housing may be more attractive than other social programs because of its high visibility factor, i.e. housing projects such as public housing are more obvious than food or health programs. There is an additional argument that housing by the public sector, especially where home ownership is involved, will stabilize a prevailing socioeconomic system.

Spatial Effects

Two considerations of spatial aspects are the regional extent and distribution of housing within the national context and the locational distribution within urban areas. Regarding the former, quality housing may be viewed as an influence on migration patterns, which is an inportant instrument in effectuating "growth center strategies." These strategies represent efforts to promote the development of lagging regions within the national economy. This can be achieved through investment policies that would enable a region to reap scale and agglomeration effects as well as investments in social overhead (housing, education, health, etc.) to make the lagging area attractive for migrants (Hansen, 1975). There are views, however, that emphasize housing as being a condition rather than a determinant of migration. Grebler and Burns (1977) cited empirical evidence that housing is a weak migration stimulus. A study funded by the World Bank in 1974 reviewed eighty-nine migration studies in developed and 
developing countries and concluded that the most powerful migration determinants were economic, i.e., the expected net returns of the migratory move were more influential than housing quality.

A second spatial consideration involves locational decisions within urban areas. In the United States, the core-periphery dilemma involving income/race segregation has brought up the issue of, "opening up the suburbs," or racial and socioeconomic integration. Heilbrun (1981) reviewed several policies that were designed to encourage racial and economic dispersion.

The policies were classified as "permissive" or "active." The former refers to actions that aim at removing discriminatory practices, including exclusionary zoning, but do not directly subsidize housing, e.g. the Civil Rights Act of 1968, which outlawed discrimination in housing. "Active" policies, on the other hand, would directly lower housing costs for the poor. One approach involves establishing a state or national housing authority with the power to build or lease housing for the low income clientele. This housing authority would utilize national or state criteria for planning and locating housing so as to override possible local resistance to integration. 
Macroeconomic Effects

The rationale espousing the stimulation of the economy by utilizing housing investments as countercyclical instruments as well as job and income generators is a controversial one.

Macroeconomic stimulation was an issue rooted in the history of the U.S. involvement with housing. The earliest federal housing programs were started during the Great Depression of the 1930s. The Public Works Administration was authorized to construct or finance public works including public housing. At the forefront of housing programs was the promotion of economic recovery by creating additional employment. This notion was so important that in 1935 the housing program funds were cut in half when it was decided that alternative public works provided more jobs in a shorter time (Weicher, 1980). The earlier efforts were thus more oriented toward the production rather than the consumption of housing. There are schools of thought that believe that the thrust of housing policy in the U.S. is still oriented toward that end. Marcuse (1979) expresses this production over consumption predominance in a rather sharp criticism of the concept of a, "benevolent housing policy," 1 .e. one geared toward the solution of social problems of housing. His view is that benevolent housing policy is a false concept based on an analysis of public housing programs. 
A conceptual basis of housing investments may be viewed as the additional benefits to the economy, e.g. Solomon (1974) defines the housing employment benefits as the value added in earnings over and above what these earnings would have been without the housing investment decision. In evaluating housing effects on the economy, Varaday (1982) claims that the reasoning based on housing subsidies being a stimulus to the economy is spurious because other federal programs work toward that macroeconomic goal also, and if compared, they too would provide the stimulus. This view, however, was not backed by any empirical evidence.

A problem exists in identifying the benefits of housing investments on the economy. As far as federal (or central) government efforts are concerned, regional and local economies will be likely to respond differently to national changes in the business cycles.* For example, Vaughan (1980) examined the U.S. labor markets cyclical behavior by region from 1960 to 1970 and found that there were large variations among metropolitan areas in employment cycles in response to national trends because of their larger, more diverse economic structures which reflected the nation more so than smaller areas. Responses were measured by conformity to national trends as

\footnotetext{
* Business cycles can be broadiy defined as the secular growth rate of the economy and fluctuations thereof.
} 
well as market responsiveness and the extent of lead or lag times. Regional variations in economic structure thus complicate the evaluation of housing policies in terms of their macroeconomic stimulative effects,e.g. if a given region has low unemployment or has a building material constraint that is not typical of the national scene, efforts to stimulate the econory through housing (or other public works type programs) will cause inflation until the regional bottlenecks are cleared.

On the national level, Weicher (1980), points out that due to the inverse relationship of housing construction activity to interest rate levels, government investment in housing may allow production expansion easily when interest rates are low, when other industries are declining and releasing idle resources, i.e., during recessionary times. The ex post facto record, according to Weicher, has yielded a different finding. Several examples were cited (Weicher, 1980, p. 9):

(1) The Section 221(d)(3) program--which basically subsidized interest rates on mortgages for privately owned apartments, was initiated in 1961 to aid the housing market, which was in a recession. Overall housing production reached "impressive" levels $(350,000$ units from 1960 to 1963) before the program reached its maximum 10,000 units per year in 1964 . 
(2) Similarly, Section 8 new construction--where the federal government subsidized private developers and state housing agencies by guaranteeing a certain minimum rent above that which would be paid by the low income residents--was enacted in 1974, which was a recessionary year for housing. The housing industry recovery took place before the program's achieving its peak of 125,000 units in 1977.

(3) Fublic housing has had little demonstrated effect on overall housing production since its inception, according to a 1978 Congressional Budget office review. It was also noted that there were long lead times required for site acquisition and construction.

(4) Subsidized housing production appeared to have substituted for unsubsidized production that would have taken place anyway. Specific programs were cited including Section 221 (d)(3), Section 235 and 236 , all of which were interest rate subsidy programs. It was also claimed that private construction levels were actually dampened by the additional vacancy rates caused by public housing.

(5) Encouraging production for the non-poor appeared to generate a greater macroeconomic stimulus than 
income tested programs. Hendershott and Villani (1977) found that government mortgage assistance affected housing starts initially, but its effects faded over the business cycle* Weicher concluded that the evidence is weak in making a case for federal housing policy's achievement of broad economic goals.

Grebler and Burns (1977) conducted a more thorough analysis of the macroeconomic effects of housing investment. In addressing employment effects, the assertion was that housing would be a good employment generator because of the relatively large proportion of unskilled workers required, as well as the relative ease of entry into the industry. This issue tries to make a case for the housing industry being a point of entry to the urban labor market, especially for recent migrants. It is justified to the extent that net increases in product result over other possible employment possibilities.

The extent of forward and backward linkages also determines the effectiveness of housing policy on the macroeconomy. Forward linkages are those linking housing to consumer-oriented industries such as furniture, carpeting, etc., whereas backward linkages are those

* This finding was cited in a study of the "Tandem Plan," which involved interest rate subsidies to lenders who were to pass the reduced rates to builders and home buyers. 
linking the industry to raw material industries, such as concrete, lumber, etc. Empirical evidence for Mexico indicated that construction was one of the higher employment generators, with low cost multi-dwellings being the highest. This evidence was supported by employment figures for Venezuela and Columbia (Grebler and Burns, 1977, p. 196).

Employment effects naturally lead to income effects, a function of the multipliers for a given country or region. In a World Bank study, income multipliers for Columbia, Korea, Mexico, and Pakistan were found to converge on a value of two. Thus, for every dollar spent on construction, a net effect of two dollars was generated throughout the economy (Grebler and Burns, 1977, p. 196).* The effect of housing on savings was also addressed. Home purchase or renovation was viewed as a powerful stimulus to savings, which would be a favorable condition toward improving capital shortages, especially in poorer, less developed economies. To the extent that saving occurs, reduction in current consumption results and that has a dampening effect on possible increases in consumer spending. This lattar effect, regarding the ievel of prices, has been viewed as being subject to the source of financing leading to an increase in demand for housing as

*These multipliers should be interpreted with caution since it was not clear how they were derived. 
well as the strength of linkages between the final demand sector and the intermediate supply sectors. If the increase in demand for housing is financed internally or domestically, decreases in the demand for other nonhousing goods should occur or else pressure would be put on prices. If the increase in demand is externally financed, e.g. through foreign aid, proportional reductions in non-housing goods and services need not necessarily take place in order to insure price stability. Using data for Mexico and Korea, Grebler and Burns (1977) analyzed price effects die to increases in construction output and found that the expected price effects of two ambitious housing programs in those countries were minimal--around 1.5 percent for Korea and less than 1 percent for Mexico.

Finally, the effects of the housing sector on the balance of payments is expected to be small, but it is difficuli to generalize. Some of the derived demands due to housing, e.g. for carpeting, may require an increase in imports and thus a worsening of the balance of payments. On the other hand, to the extent that housing may replace activities in other sectors which had higher import requirements, an improvement in the balance of payments should occur. Broad generalizations regarding balance of payments effects stress the relatively low dependence of the housing sector on iniports due to the comparative ease of substitution of indigenous products for foreign ones as 
well as the weight and bulk of building materials which, when coupled with the geographic dispersion of the housing sector activity, make imports less competitive.

The above discussion of the macroeconomic rationale for housing investment provides a mixed view. On the one hand, there are definite positive effects on the economy to be expected from housing programs; but on the other hand it does not appear that these effects by themselves would justify a housing investment scheme in lieu of other sactoral investments. Furthermore, the exact effects would be difficult to predict and generalize before the fact.

\section{Efficiency}

A final rationale justifying housing support is that inefficiencies do exist in capital markets and in the construction activity itself. Regarding the former, it is obvious that housing takes a substantial portion of a household's budget, especially for home ownership and where there are no financing facilities to handle mortgages. One of the very important roles by which governments have aided the housing market is through finance, i.e., to close the gap between the timing of given income streams and the prevailing shelter costs. The importance of this issue is illustrated in the fact that the formation of the Federal Home Loan Bank System in 1932 and the Federal Housing Administration in 1934 in the U.S. were viewed as being successful in promoting home ownership in the U.S. Home 
ownership increased from 44 percent in 1940 to 65 percent in 1976 (Weicher, 1979).*

Regarding the construction sector itselt, it was claimed that building houses takes time so that the supply of housing cannot be increased sufficiently to deal with the increasing demands for shelter. Montgomery and Mendelker (1979, p. 49) state for example that, "since housing is so complicated, fixed in space, and necessarily expensive, changes in supply occur slowly or not at all." Rather than accepting the above simplistic view at face value, review of the literature reveals different housing supply expectations.

First, the concept of housing supply elasticity shall be defined as a measure of the percentage change in quantity for a given one percentage change in price. It is a measure of the responsiveness of housing.

Secondly, the short versus long run shall be identified within a resource context. For example, having at least one fixed resource would imply the short run, whereas the long run implies no fixed resources.

In response to a demand increase for housing, the following supply responses were identified as

*FHLB is a financial system designed to provide liquidity for mortgage holding institutions. FHA was designed to insure housing loans so as to stabilize and facilitate sound home financing. 


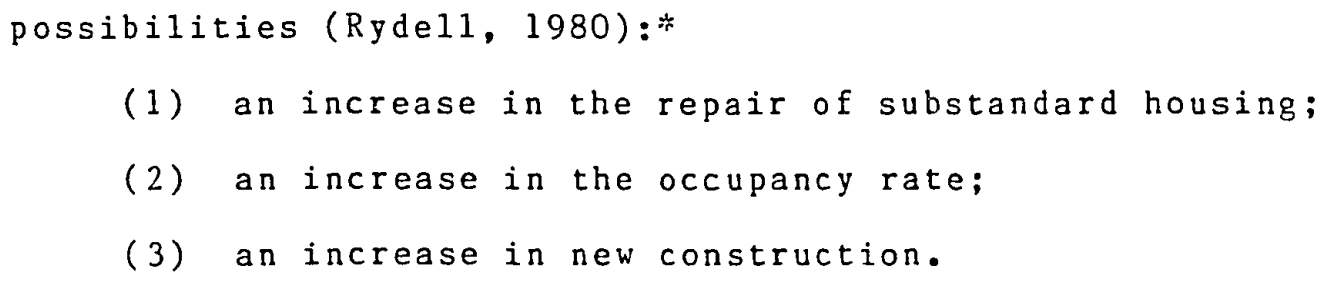

The first two responses typically characterize short term responses to a demand increase for housing. The last listed response is likely to make greater demands upon building resources and to take a longer time to adjust. Additionally, 01sen (1976) ciaims that there are houses in the building stage whose completion can be speeded up in response to a short run price increase. 0lson also claims that a change in demand may be due to a change in the number of households and/or a change in the demand for housing quality (as in (1) above). The implication of this distinction is that quality changes (upgrading, painting, refurnishing, etc) to existing housing are not necessarily slow and thus the view that housing is "typical1y" slow is not necessarily correct.

In support of this view, Rydell (1979) studied the short run response of housing to rent increases.* According to Ryde11, the occupied supply curve should be elastic until

* These responses were neither mutually exclusive nor collectively exhaustive.

* Empirical results were based upon data from the Housing Allowance Supply Experiment, which was restricted to rental housing. 
the vacancy rate approaches zero, i.e., the vacancy rate may be viewed as the "fulcrum" upon which supply and demand equilibriate, the case here being similar to frictional unemployment in labor markets. When the occupancy rate is close to 100 percent, rents and house values wouid rise, leading to an adjustment via construction or filtering (both of which are long-run adjustments).

Muth (1960) investigated the supply of urban housing by observing the behavior of factor inputs (material and labor prices) and the rate of entry of firms into the home building industry. The data examined was for the U.S. and it led Muth to conclude that the supply of new housing was elastic in the long run. One of the limitations of the Muth study is that by addressing new housing only, the majority of the housing stock, i.e., the existing stock, was not included. Deleeuw and Ekanem (1971) focused their study on the long run elasticity of supply of housing services. Housing services was to denote a quantity of services $y$ ielded by a unit of housing stock per unit of time. Data of 38 metropolitan areas in the U.S. were analyzed and results indicated that the long-run supply was generally low and when segmented into low, medium, and high rents. Elasticities were correspondingly lower for the low rent segments. 
Ozanne and Struyk (1977) performed an empirical analysis of the supply elasticity in the Boston Metropolitan area over a ten-year period (1960-1970) for both rental and owner occupied units. Their findings were that the supply was inelastic. This, however, was criticized on the grounds that the analysis excluded most of the ways that markets would respond over time to price changes (Rydell, 1980). Additional criticisms by Quigley (1979) and Grieson(1973) addressed design and methodological errors in the 0zanne/struyk and Ekanem/DeLeeuw low estimates.

An extremely important issue arising out of the above discussion is that even if the housing market is not very reponsive, this condition does not necessarily warrant public involvement in the form of constructing housing units. It would appear that a reasonable approach would involve identifying the causal elements that led to the supply inelasticity, e.g. if the inelasticity is caused by shortage of entrepreneurial skills or a general inability of the private sector to respond to the need for more housing as expressed in rising prices, then government involvement would appear to be warranted. If, on the other hand, bottlenecks facing the construction sector are due to government action itself, e.g. a land use policy which unnecessarily restricts growth, then government involvement would fall more into the realm of a "self 
fulfilling prophecy." A central issue here becomes the extent of the shortfall in the competence and/or ability of the private sector to achieve a given nation's qualitative and quantitative housing goals.

The supply responsiveness issues may be better addressed in a normative framework which will be elaborated upon later.

\section{Housing Policy Strategies}

In very general terms, there are two types of policies by which governments can effect the quality and quantity o: housing. The first group may be termed demand support policies and they refer to actions that influence the consunption aspects of housing. The second group are supply support policies and they refer to actions that influence the production of housing.

Musgrave (1976) set up the following typolog: regarding strategies and instruments for low income housing

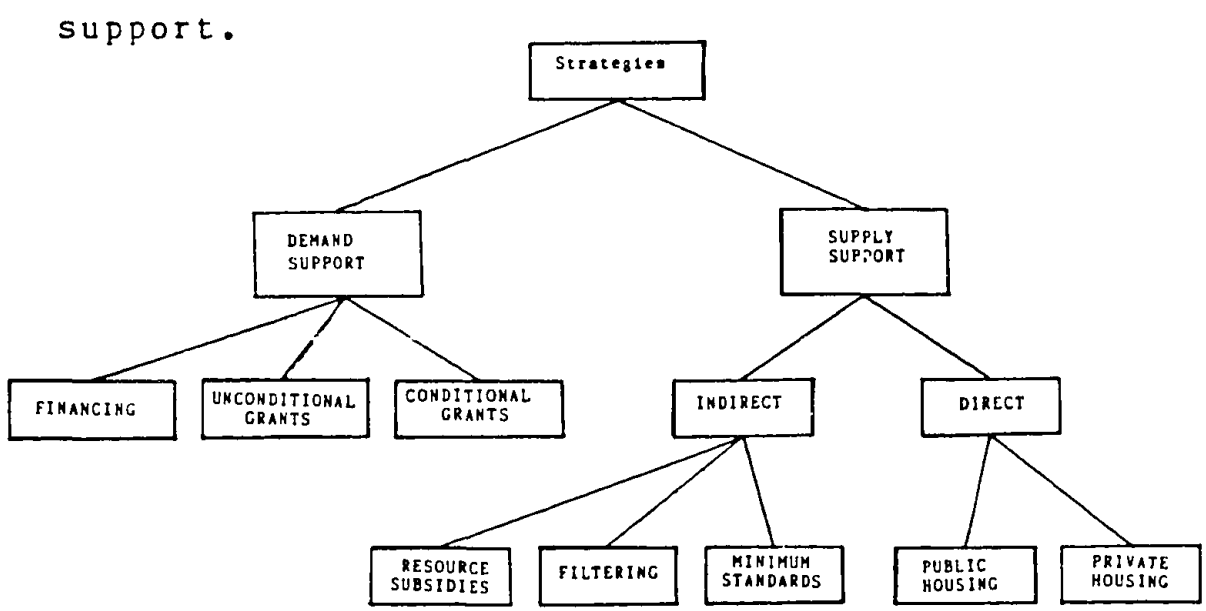

Figure 2. Strategies of Housing Support Source: Musgrave (1976, p. 225) 
Demand Support

These are subsidies given to the tenant or owner-occupant.

General Income Maintenance. These involve direct payments with no strings attached, but suffers from two main features. First, a portion of the transfer may be spent on non-housing goods,* which is a drawback when merit good aspects are considered. Second, to close a housing poverty gap (the amount of money needed to elevate households out of poverty) to a given defined poverty line would imply a difficult choice. That choice will be in either imposing very high implicit marginal tax rates on those just above the poverty line or providing subsidies to households well above the poverty line, i.e., the technical structure of income maintenance programs in general has three components (Heilbrun, 1981, p. 313):

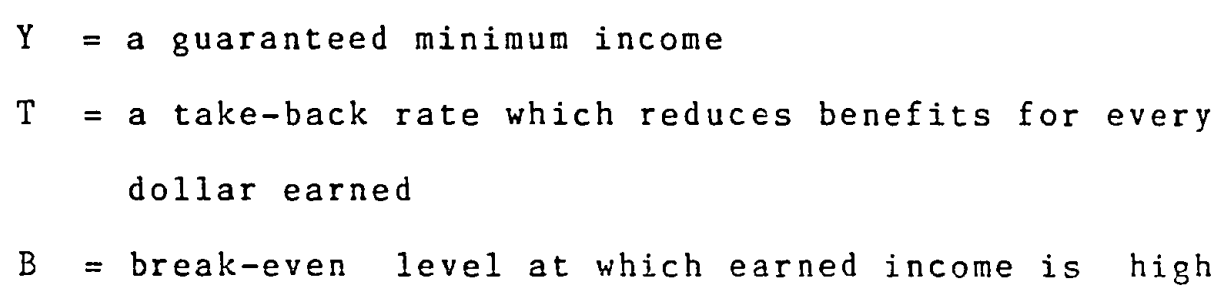

The relationship between the elements is $B=\frac{Y}{T}$.

As an illustration of the claim made above, let $Y=20,000$ riyals* per year and $T=0.30$ (a 30 percent take-back

* Determined by the income elasticity of denand for housing, i.e., the percentage increase in housing expenditure for a 1 percent increase income.

**One Saudi Arabian riyal $=\$ 0.30$. 
rate). This implies that assistance by the government will stop at $B=\frac{20,000}{0.3}=67,000$ riyals per year 1evel. Notice that to lower $B, T$ will have to be set at a higher level, i.e., a higher margiul tax rate. II riag alsc te lowered, which impacts the needy.

Two relevant issues to be gained from the above are that a choice has to be made between imposing a very high marginal tax rate for those just above the cut-off income or extending income benefits to those well above the minimum income (in the example above, to those with annual incomes of 67,000 riyals or $\$ 19,700$ ). The second issue of concern here is that to the extent that expenditure leakages into other items such as food and health care occur, the effectiveness of this support will be inhibited. One of the greatest disadvantages with general income maintenance is that it does not address "merit" aspects of housing consumption discussed earlier.

Earmarked Grants

These are justified where meritorious characteristics of housing consumption are concerned, as mentioned earlier. A special case of demand support are housing allowances which are basically payments made directly to low income eligible households to help them pay the costs of living in housing of their choice as long as it meets certain minimal standards. Demand support subsidies have been fairly common in the U.S., e.g., the Section 23 leased (existing) 
housing program where government leased modest standard housing at market prices and subleased the units to eligible households. The rent supplement program also provided income related subsidies to tenants of privately owned units (Allen, et al, 1981) and also the Section 8 "Existing" which acted as an income transfer for tenants subsidized in place (Weicher, 1980).

In general terms, the arguments for demand support policies include the following:

(1) They are more equitable in that they provide recipients with units comparable to those households just above the income limits for low income recipients.

(2) They are usually less expensive than new construction type supply policies.

(3) They have the potential of being more accessible to a greater number of people.

(4) They do not suffer from spatial concentration problems typical of supplytype subsidies.

(5) Demand support policies that utilize the existing stock would encourage more maintenance and thus help preserve the investment sunk in the housing stock (Carlson and Heinberg, 1978, pp. 49-51).

Criticisms of demand support policies include: 
(1) They have a tendency to inflate housing prices, especially where time lags or housing supply inelasticity exists.

(2) They transfer wealth inequitably from the lower income households to their landlords if the above condition applies.

(3) Because demand support policies are usually not large enough to induce recipients to acquire new units, it was concluded by some that the supply of new units that are acceptable would not increase (Allen, Fitts, and Glatt, 1981).

A final note regarding demand support policies is that they have represented the major part of the federal housing policy in the U.S. for middle and upper income households. This policy manifested itself in the form of itemized tax deductions for homeowners which worked out to an average of a 15 percent reduction in the price of owner-occupied housing (Quigley, 1980). Additionally, the imputed rent income derived from home ownership was not taxed. By contrast, the thrust of federal housing policy for low income households has been supply support oriented up until 1974, when several demand support policies were enacted.

\section{Supply Support}

As the name implies, these policies are directed at the supply side (or suppliers) of the housing market. 
Minimum Standards. In general terms, a policy which sets and effectively enforces minimum standards will reduce the supply of housing available to low income families (Husgrave, 1970, p. 226). Standards naturally may serve a vital role in protecting tenants against inadequate rental contracts, as well as playing a vital role in assuring public safety. The drawbacks of minimum standards have been mentioned earlier in this chapter. They include higher costs and delays in the construction process. These drawbacks must be more than balanced by the public health and safety promotion effects.

Filtering. Downs (1969, p. 649) sketched several housing strategies, among which filtering was described as, "...involving strict enforcement of high or moderate quality standards for all new construction....and public subsidies focused primarily on middle or upper income households. Poor households receive units through filtering down of older units from higher income households." It should be noted here that filtering is a supply support subsidy from the viewnoint of the low income groups. It may be a demand subsidy for the higher income groups, i.e. the middle and upper income households would view filtering strategies as housing consumption stimuli.

Public housing. Public housing stands today as the oldest and largest housing program in the U.S. (Weicher, 1980). 
It has the following drawbacks:

(1) High construction costs: In the U.S., this has been primarily attributed to the DavisBacon Act of 1931, which required federal construction projects to pay the prevailing wage scale in the local area to all workers in public housing projects.

(2) High land costs: In the U.S., it was the traditional practice to build housing projects on fairly expensive land in large cities due to the fact that public housing was tied to slum clearance as a joint effort to improve housing conditions.

(3) Operational problems: Primarily management problems have been cited, especially regarding responsiveness to repair and maintenance.

(4) The lottery feature: Muth (1970) emphasized the point that public housing projects can only be enjoyed by a few of the applicants, thus the analogy to a "lottery," i.e. extensive screening has to be performed in order to accept dwellers and waiting lists tend to be longer than vacancy rates.

The above does not imply that public housing is doomed. Several examples exist of we11-built, reasonable 
cost, well-managed public housing programs, such as in Singapore, where almost seventy percent of the population resides in public housing projects--both rented and owned. (Singapore Housing Development Board, 1982).

This example of public housing successes may be the exception rather than the rule. Linn (1983) specifically mentions the Singapore public housing experience as an exception to the generally poor record of public housing in developing countries. Success in the case of Singapore was attributed to several factors, which included affordable standards in design, cultural and social acceptability of the units, the availability of a large enough fiscal base to support the programs, and sufficient management and technical resources, as well as powerful local governments to implement the projects.

\section{Rent Control}

This is perhaps one of the most controversial policy instruments. In a strict sense it may be viewed as being a tactic rather than a strategy, i.e., it has a short-term reactionary focus rather than a long-term planning one. Meeks (1980) cites an empirical study in the Washington, D.C. area which concluded that controls wili dampen investment in new housing. However, it was also found that occupants of rent controlled units were poorer and that if removed, major rent increases occur for lower income households (Meeks, 1980, p. 1983). The difficulty 
in deciding to implement a rent control should weigh the concerns of weighing low income households' availability and cost issues in the short run versus private sector investments in housing in the long run. An "ideal" rent control would balance those concerns so as to minimize the potential conflict between social equity and economic efficiency.

\section{Toward An Aprilicable Theory}

The literature review thus far has utilized theories and empirical works that are predominantly American. A housing investment theory to guide and evaluate the Saudi Arabian housing policy will be required to be applicable to the country. The question may first be asked as follows: Is there a universal theory of housing investment?

\section{Universal Applicability}

Attempts to explain housing investment and consumption variations between countries were attempted by Grebler and Burns (1977) and Strassman (1970). Considering the economic determinants capital was to be invested in housing as long as the expected marginal return exceeded the expected returns in other non-housing sectors. At lower development levels (defined in terms of Gross Domestic Product per capita) residential construction returns were exceeded by other activities. Data for thirty-nine 
countries over 1963-1970 were analyzed by Grebler and Burns (1977), who found that poorer countries allocated lower shares of resources to housing. This was quantitatively expressed as tie ratio of new residential construction to Gross Domestic Product. At an intermediate stage of development, greater shares were devoted to housing, and beyond that stagealternative non-housing investments outbid housing--and the richest countries again allocated lower shares to housing. An historical trend analysis for the United States revealed the same basic trend, i.e., by analyzing the ratio of residential construction to GNP from 1891 to 1970 it was found that the ratio was declining. It was stated by Grebler and Burns that the beginning of the time period considered, whici was the late nineteenth and early part of the twentieth century, was the mid-range of economic development. The reasoning explaining the decline in the "theory" describing housing share in a given development stage was expressed as being due to two elements: first, as a nation progresses past some middle development level, non-housing goods and services start competing for consumer and investor's dollars. Secondly, the additional demand for housing can be accommodated by investing in the established existing stock in addition to new buildings.

The conclusion from the above was that the "share of housing in the total product of advanced countries is no 
sure guide to the relationship 'proper' for all countries..."(Grebler and Burns, 1977, p. 41).

A universal theory of housing investment would be difficult to conceptualize, given some of the rationales reviewed earlier in this chapter. Examples of these include:

(1) Equity: The equity rationale, with its connotation of a "fair distribution of adequate housing," and its merit good implications, is likely to be different between countries, given the different norms that exist.

(2) Internal Benefits: The effect of improved housing on mental and physical health was found likely to be affected by social and psychological processes of reaction, adaptation, and accommodation. These were, in turn, likely to be influenced by cultural elements, which differ internationally, making general predictions difficult.

(3) Macroeconomic Benefits: As mentioned earlier, regional variations in economic structure would tend to complicate evaluations of housing based stimulation effects. National differences in economic structure also would likely have that effect. Additionally, international variations in the extent to which public sector housing 
construction would displace private sector housing construction would further complicate the analysis.

(4) Efficiency: This rationale is probably one where a few broad generalizations can be safely made for developing countries. Inefficiencies in capital markets almost always exist, not only because of capital shortages, but also because of a general lack of expertise in that area (Abrams, 1964). Inefficiencies in the construction sector itself were identified by Smith (1980, pp 173181) and include land where land based wealth is lihely to be the main source of economic and political power, thus fuelling land speculation. Building materials were also likely to be a constraint because of inabilities of developing countries to become self sufficient in this resource to reduce reliance on imports. Even though labor is assumed to have an elastic supply due to the abundance of workers and the general absence of wage rigidities, higher skilled and professional workers may not be available in abundance. Specific problems may also be encountered in the supply of entrepreneurial talent for a given underdeveloped country, especially where economies of scale necessitate 
large scale contractors, making entry into the industry difficult.

It appears that a universal framework to guide housing investment is difficult given the lack of generality of the rationales as reviewed, i.e., what may be applicable in one country may not be applicable in another, especially where cultures vary. Even though this finding may appear rather obvious, it has very serious implications.

Goal setting and strategy designs necessitate a culture-specific approach which involves the rationales stated earlier. Importing know-how from Western developed countries to design strategies for alleviating housing shortages may fall into the trap of specifying programs and even policies based upon developed countries' experiences. As far as strategies of housing support are concerned, it is likely that the prevailing sociopolitical framework in a given country will be the main policy determinant over and above some "rational" sectoral benefit/cost approach. For example, in centrally planned systems, the greater likelihood is towards supply support strategies. This is because the size and capability of the private construction sector is likely to be relatively small. Even if construction inefficiencies were caused by public sector activity (or inactivity), likely actions would aim at tackling those issues utilizing public sector actions. In market type economies, the greater emphasis will 
likely be given to demand support policies where the market mechanism is utilized to reveal and satisfy housing demand.

\section{Summary and Discussion}

This chapter started out by reviewing the basis for housing policy. An explicit assumption was made that by delineating the rationale for housing policy, its evaluation and analysis could be better performed. Several rationales were discussed and the relevant literature was reviewed. It was found that some of the widely accepted intuitive reasoning justifying housing support was challenged or not evident in several empirical works. The research efforts, which were primarily focused on the United States tended to yield inconclusive results for the following basis of housing support: the effect of poor housing on mental and physical health, external effects, spatial effects, macroeconomic stimulation, and efficiency. A general theory was viewed as being unlikely, given the intercultural variation between countries, however several issues were likely to be important in generally guiding housing policy: the normative framework in a given country would define equity in resource distribution and housing assistance. The framework will likely be a decisive factor in determining whether market "imperfections" should be solved by helping the private sector or, alternatively, by replacing its activities. 
Another issue which is likely to guide housing policy is the extent of inefficiencies that exist, especially in developing economies in the areas of finance and building within the housing markets. The inefficiencies were identified as being common in less developed countries, but they were not confined to private sector activities, i.e., public sector inefficiencies also exist within the housing area.

In analyzing and evaluating the Saudi housing policy, the rationales reviewed in the literature will be addressed and their applicability will be examined. 
CHAPTER III

THE SAUDI ARABIAN POLICY SETTING

Introduction

This chapter provides an overview of the Saudi housing policy determinants. We will begin by constructing a normative framework and then move to a discussion of the national development environment and direction as expressed in the Five Year Development Plans and miscellaneous growth statistics.

An exposition of the housing sector will be provided provided using Jeddah, the second largest city in the Ringdom, as a case study to illustrate demographic changes, housing types and conditions, and housing sector problems in genera1. These will form the basis for understanding the housing policy which will be discussed in the next chapter.

\section{Policy Determinants}

\section{A Normative Framework}

The importance of delineating and understanding the 
normative framework that exists in the Kingdom is explained by the fact that cultural norms typically identify equity. Equity in turn would explain a "just and fair distribution" of goods and services, including housing, as outlined in the previous chapter.

The religion of Islam represents a basic element in the Saudi Arabian culture and government. The Qur'an is the Kingdom's constitution and Islamic law (Shariah) is basically the law. Saudi Arabia is viewed, and considers itself to be, the guardian of the two Grand Mosques in Mecca and Hiedina (A1 Haramayn). Additionally, Islam was the cohesive force by which the Kingdom had united and was declared an independent country in 1932.

The Islamic Welfare State

A central function of the Islamic state has been described as ensuring the good life and welfare (al falah) and alleviating hardships. This was in turn realized where fulfillment of the basic needs in the life were satisfied, including adequate food and clothing, and housing (Zarqa, 1980; Chupra, 1980). The state would be expected to be involved in certain basic functions, including the following (Saqr, 1980):

Realizing better utilization of economic resources. An example of this function would include the historical basis 
of land ownership, which was land productivity, i.e. land ownership was granted traditionally to those citizens who could, through their own work, make it productive.

Establishing and Applying Standards. In traditional Islamic societies a system by which standards for goods and services were established and applied was called "al ihtisab." This system was a complete set of rules to regulate activities and standards of various trades, to prevent counterfeiting of products, and to set building standards.

Even though building regulations have been established, a building code has not been put into effect thus far.

Interfering in Markits to Control Prices. When absolutely necessary, the State can intervene to regulate prices where exceptional conditions exists, such as wars or natural disasters. Practices or conditions leading to a reduction in supply that have unfavorable implications would justify government action to correct the situation. Included under this category were rent controls.

Realizing Equitable Income and Wealth Distribution. This principle accepts the basic fact that different innate acquired capabilities, tastes, and willingness to produce do exist, which implies differences in wealth and income. These in turn are viewed as being conducive to production 
because of the underlying incentives. However, concentration of wealth and tremendous income inequalities are not accepted in Islam. (Qutub, 1982, p. 92)

To deal with the inequalities in income and wealth, two kinds of instruments were available in Islam. The first involves builc-in instruments, which are indisputable and unchangeable, such as the "al zakah" and spending for charity (or Awqaf), both of which will be discussed below.

The second redistribution instrument is discretionary. It varies according to societal needs and the extent to which the built in instruments can reduce inequalities. These include taxes and limitations on real estate ownership.

The concept of income and wealth distribution is generally covered under "social guarantees" in Islamic political economy. Two basic principles corresponding to the instruments mentioned above are, general equality-which aims at guaranteeing basic needs for less privileged groups by individuals. A pivotal instrument under this principle is "Zakat," an undisputed cornerstone of Islam which is a fixed 2.5 percent tax on wealth (money balances, jewelry, etc.) and variable tax rates on income. (Saqr, 1980 , p. 65). Zakat revenues are collected by the State, which is responsible for redistributing income by transfer payments and in-kind assistance. (Siddiqi, 1980). 
The second principle involves the right of citizens to public resources, i.e. the state here was viewed as being responsible for guaranteeing "adequate" living standards for the needy so that living standards should increase as public wealth increases. (Al Sadr, 1977, p. 632) As public resources increased, so should the living standards. other sources to alleviate poverty include "Sadaqa," which represents a voluntary charitable contribution by individuals and finally, the "Waqf" or endowment which represents a charitable, usually non-movable contribution to the poor and/or disadvantaged. The "Arbitah" or endowment "Housing for the Poor" is an example of "Waqf." They are donations made by citizens to less fortunate households. It should also be noted here that endowments can be in the form of cash (which is controversial) as illustrated by Mandaville (1979).

There are other functions of the Islamic State, but the four mentioned above are the most relevant for identifying the Islamic normative basis for purposes of housing support.

The Development Environment

At the time of the consolidation of the different regions by King Abdul Aziz Al-Saud, and the formation of the Kingdom of Saudi Arabia in 1926, the economic status of 
the country was poor. The national income primarily consisted of fees collected from Moslem pilgrims to Mecca and Medina (the Islamic Holy places) as well as some trade (DeQuin, 1976; Nyrop. 1977). It was not until 1938 when the Arabian-American oil Company ARAMCO) struck oil and that country's wealth began to emerge. The wealth of the Kingdom was directly linked to the prevailing conditions of the world oil situation, which was unfortunately volatile, and experienced a decline in crude oil prices between 1950 and 1970 (Nyrop, 1977, p. 252). In 1974 the price of OPEC oil increased by more than 100 percent to U.S. \$11.25, which led to an enormous impact on government revenues. Estimates of the contribution of oil to total revenues in 1970 were placed at 89.2 percent (Ministry of Planning, 1982). All the petroleum that was produced, as well as reserves, which are the largest in the free world by some estimates, are government owned. In 1970 estimates of crude oil reserves were placed at 167.5 billion barrels or one quarter of world reserves (Ministry of Planning, 1980.) Figures 2 and 3 illustrate the increases in oil production and the consequent increases in revenues and expenditures for the Ringdom.

The economy witnessed a tremendous growth in revenues and expenditures (which increased by forty- and thirty-fold respectively over the decade). To manage this growth in a 


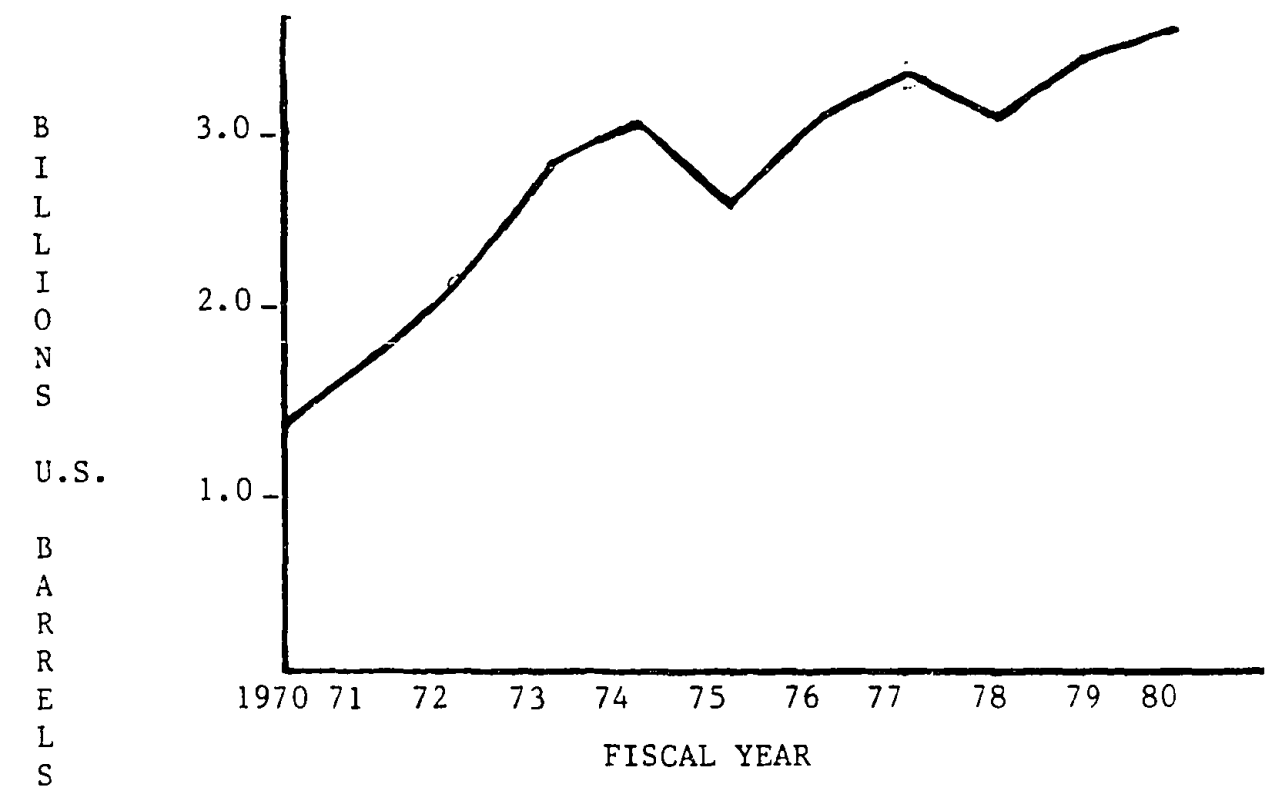

Figure 3. Crude Oil Production, 1970-80

Source: Ministry of Planning, 1982, P. 3

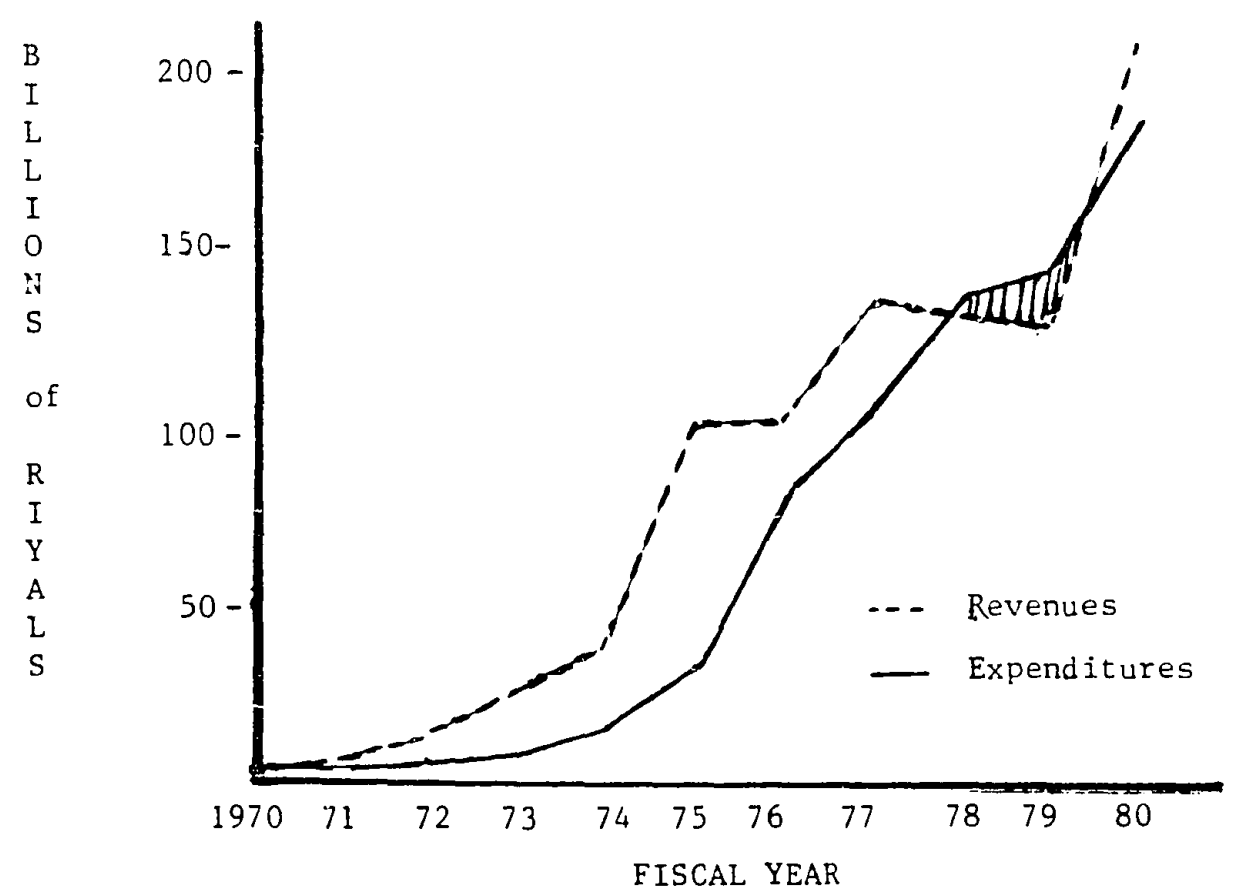

Figure 4. Government Revenues and Expenditures, 1970-80 Source: Ministry of Planning, 1982, p. 25 
rational, effective manner, the Kingdom initiated a national planning effort to be conceptualized and produced by a specialized government body, the Ministry of Planning. This Ministry is responsible for preparing status reports on the national economy which act as a basis for formulating broad planning strategies. These strategies are transformed into workable recommendations and specific criteria with the help of the other ministries of concern. Final approval is granted only by the Ring. Follow up and monitoring is usually conducted by the Ministry of Planning. (Nyrop, 1982, pp. 238-9) Specific funding areas would be the responsibility of the Ministry of Finance and National Economy. The development plans of the Kingdom are summarized below (Ministry of Planning, 1976, 1980):

The First Five-Year Development Plan (1970-75)

The general strategy of this plan was to ensure continued growth in the economy, to extend and improve infrastructure, to improve government services, and to develop human resources through education and training.

Achievements of the Plan included an increase in the Ringdom's share of oil revenues without drastic nationalization measures. In addition to this, international oil prices were set by producing countries 
and not oil companies. On the domestic front, total budget allocations increased for physical infrastructure, education, social services.

The Second Five-Year Plan (1975-80)

The general strategy of this plan was to further develop the country's physical infrastructure, to develop the hydrocarbon resources and industries so as to maximize resource conservation and industrial use, and to develop a stronger private sector that could actively participate in the development of the country.

Achievements included a growth in gross domestic product that averaged 8 percent annually and a 13.3 percent annual ayerage growth rate for the non-oil sector in real terms. An "adequate" infrastructure network was also developed during this period and in the later years of the Plan inflationary pressures--which had soared due to the increases in the budget--were reduced. Finally, real growth in per capita Gross Domestic Product was approximately 26.4 percent over the period 1975 to 1980.

The Third Five-Year Development P1an (1980-1985)

The general strategy of this plan emphasized selected, rather than general, growth areas in the economy. It also called for consolidation rather than expansion of the foreign labor force. In fact, the plan stressed the 
replacement of foreign workers by Saudis to the maximum possible extent.

Specific broad policy objectives were identified as follows: (Ministry of Planning, 1980, pp. 16-17)

(1) To induce structural changes in the economy through diversification of the economic base as well as insuring maximum value added from crude oil production in petroleum related industries. Additionally, the role of physical infrastructure improvements is reduced relative to the previous plans.

(2) To promote efficiency in both the government and private sectors through manpower-related programs as well as administrative changes in government organization and procedure. This objective also included ensuring adequate finances to effeciently utilize infrastructure and plant machinery.

(3) To promote participation of citizens and Social Welfare for Saudi Arabians in Development including a regional public investment program to ensure development to the full potential. Additionally, public information programs and religious and 
social guidance were given high priorities to ensure the public awareness of their role in development as well as ensuring religious and social guidance.

Achievements of the Third Plan cannot be fully assessed thus far because there is over one year left before the plan time frame expires. However, it should be mentioned that the level of prices has been reduced, and the structural change in the economy appears to be progressing as evidenced by the development in the two new industrial cities of Yanbu and Jubail.

Several important issues resulting from the plans and related to housing, should be noted.

The national economy underwent a structural change over the period 1970-1980. The non-oil sector has experienced a gradual growth from 43.6 percent in 1970 to over 50 percent in 1979, with the trend expected to continue. (Ministry of Planning, 1982)

Gross Domestic Investment underwent a significant change over time with construction of buildings holding a significant role of total assers.

The development plan's manpower requirements were morn than could be satisfied by the indigenous work force in terms of sheer numbers and also in specialties. Steps were thus taken to accommodate a larger number of foreign 
workers at all levels while simultaneously expanding upon investments in local manpower through education and training.

The non-Saudi manpower growth rate was approximately 16.5 percent annually compared to the Saudi element growth of 2.4 percent per year in the period 1975-80. (Ministry of Planning, 1980)

The general cost of living increased at a fast rate but stabilized towards the end of the decade.

The Housing Sector

Demographic Changes

In response to employment and general business opportunities, which were enhanced by the developrent plans, the urban areas experienced an inflow of migrants from the rural areas and from abroat. In 1970, approximately 36 percent of the population resided in urban areas. In 1980, 54 percent of the total population lived in urban areas with 41 percent living in metropolitan areas with a population of over 100,000 (Ministry of Planning, 1980). According to an estimate by the consulting firm, SCET, (1975). The urban population is likely to reach 84 percent 
TABLE III

COST OF LIVING CHANGES RINGDOMWIDE 1970-80

Indexes $(1970=100)$

\begin{tabular}{lllll}
\hline & Housing & \% Change & General & \% Change \\
\hline 1970 & 100 & - & 100 & - \\
1971 & 111.5 & 11.5 & 104.9 & 4.9 \\
1972 & 121.6 & 9.1 & 109.3 & 4.2 \\
1973 & 136.2 & 12.0 & 127.0 & 16.2 \\
1974 & 189.2 & 38.9 & 154.2 & 21.4 \\
1975 & 332.8 & 75.9 & 207.6 & 34.6 \\
1976 & 479.8 & 44.2 & 273.0 & 31.5 \\
1977 & 490.7 & 2.3 & 304.2 & 11.4 \\
1978 & 468.0 & -4.6 & 338.4 & 11.2 \\
1979 & 467.3 & -0.2 & 344.4 & 1.8 \\
1980 & 475.6 & 1.8 & 355.4 & 3.2 \\
\hline Average & & 21.11 & & 16.51 \\
\hline
\end{tabular}

Source: Ministry of Planning, 1982

of the total population by the year 1995 A.D.* The total population of the Ringdom was 7.012 million in 1974 by estimates of the 1394 A.H. (1974 A.D.) census. At that time there existed seven cities and towns with populations over 100,000 (Central Dept. of Statistics, 1981). * The urban population includes people living in towns with more than 5,000 inhabitants. 
TABLE IV

GROSS DOMESTIC INVESTMENT AND GROSS DOMESTIC PRODUCT $1970-80$

A. SECTORIAL SHLARES OF GROSS DOMESTIC INVESTMENT

1969 - 1970- 1971- 1972- 1973- 1974- 1975- 1976- 1977- 1978- 1979-

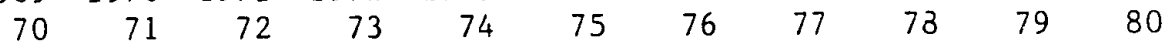

OIL

$\begin{array}{llllllllllll}\text { SECTOR } & 11.7 & 21.2 & 19.2 & 36.6 & 28.5 & 19.3 & 15.3 & 14.1 & 10.3 & 10.7 & 10.2\end{array}$

NON OIL

GOVERN-

MENT

$\begin{array}{lllllllllll}43.3 & 44.2 & 41.2 & 35.6 & 37.0 & 40.0 & 51.0 & 52.6 & 54.3 & 63.6 & 61.7\end{array}$

NON OIL

$\begin{array}{llllllllllll}\text { PRIVATE } & 37.6 & 42.2 & 36.9 & 29.9 & 25.5 & 36.2 & 31.0 & 31.8 & 24.6 & 25.2 & 23.2\end{array}$

B. SHARE OF (BUILDINGS) CONSTRUCTION III TOTAL ASSETS (\%)

$\begin{array}{lllllllllll}31.0 & 33.0 & 29.7 & 30.3 & 22.1 & 37.3 & 39.9 & 35.9 & 34.5 & 41.1 & 34.8\end{array}$

C. TOTAL GROSS DOMESTIC INVESTMENT (Millions Riyals)

$\begin{array}{lllllllllll}2806 & 2580 & 3116 & 4394 & 6586 & 7386 & 9732 & 13399 & 16178 & 14385 & 17517\end{array}$

D. GROWTH RATE OF GROSS DO:IESTIC INVESTMENT

$\begin{array}{llllllllllll}-8.1 & 20.8 & 41.0 & 49.9 & 12.1 & 31.8 & 37.7 & 20.7 & -11.1 & 21.8 & 23.9\end{array}$

E. GROSS DOMESTIC PRODUCT AND ITS \% GROWTH RATE RESPECTIVELY

$173991990722963274953164231723 \quad 3446139968420284483849127$

$\begin{array}{lllllllllll}14.4 & 15.4 & 19.7 & 15.1 & 0.3 & 8.6 & 15.1 & 5.9 & 5.6 & 9.6 & 10.6\end{array}$

Sources: Ministry of Planning, 1982; Central Department of Statistics, $1979-80$

NOTES:

1. The dates indicated are approximate. The government utilizes Hijra dates for its fiscal years and a conversion was thus utilized.

2. Percentages do not add to 100 due to errors and omissions in the official figures.

3. Total assets mentioned in category $B$ include other (non-building) construction, transportation equipment, miscellaneous machinery, etc.

4. Gross Domestic Product is expressed in retail prices. 
As far as income distribution is concerned, national data are not accessible. However, data for the City of Jeddah was acquired and the following results obtained:*

TABLE V

INCOME DISTRIBUTION BY HOUSEHOLD, JEDDAH

\begin{tabular}{lcc}
\hline MONTHLY INCOME (RIYALS) & 1971 percent & 1978 percent \\
\hline Less Than 500 & 56.0 & n.a. \\
$500-1000$ & 26.3 & 4.9 \\
$1000-2000$ & 12.6 & 19.6 \\
$2000-5000$ & 4.0 & 45.8 \\
5000 and above & 1.1 & 29.7 \\
\hline
\end{tabular}

Source: Sert-Jacksun Socio Economic Survey 1398 A.H. (1978 A.D.).

Several points need to be clarified regarding the above:

(1) The income figures have nct been adjusted for price level changes over the period 1971-78.

This does not make the distribution as good as it appears.

(2) The figures represent the total Jeddah population

* In conducting the Action Master Plans for the City of Jeddah, the consulting firm of Sert-Jackson International (U.K. ) conducted a survey of the city in 1398 A.H. (1978 A.D.). A 5 percent random sample of the total number of households was utilized, yielding $\mathbf{n}=8675$ households. The response rate was 86.9 percent. 
included in the survey. Table VI for the year 1978 breaks down the distribution by nationality indicating the higher level of income for the Saudi Arabian indigenous population as opposed to the temporary foreign labor.

(3) The figures represent disposable income since there exists no income or other personal taxes.

(4) Basic services such as medical care and education were available free of charge and were more readily available in 1978, thus improving the income situation.

The data in Table VI were based upon the 1978 socioeconomic survey. Data for 1971 were based on the results of a social survey conducted in 1971. It is likely to be biased to the extent that Saudi Arabian families are likely to be nuclear or even extended families whereas many of the foreign workers, especially the non-skilled and semi-skilled did not have their families with them in the Kingdom. Additionally, there were economies of scale inherent in sharing dwelling units by several "one man" families that would tend to enhance the income figures for foreign workers.

Finally, the overall population of Jeddah has experienced an average growth of 12.6 percent annualig-from 595,900 in 1974 to 915,800 in 1978 , based upon 
estimates by Sert-Jackson, Ltd. (1980). Jeddah's growth pattern is likely to be illustrative of the other major metropolitan areas, i.e. growth through foreign work force in migration as well as rural migration.

\section{Housing Types and Condition}

The following represents a brief overview of the dwelling types in the Kingdom (SCET, 1975):

The Sandaga (Shanty). is a small ( $3 \times 4$ or $5 \times 4$ m) rectangular structure with walls made of boards of wood or aluminum from packing boxes. It is extremely cheap, and easy to construct--especially that its building material requirements are very low. It is usually built by transient populations who are considered to be "trespassers."

Arabic Traditional. may be constructed by using mud bricks (Toob Lebin) for walls, and timber from palm trees for rcofs. Sometimes it is also called "Beyt Lebin" (mud brick house) when constructed by mud bricks. It can be constructed by using more modern materials (reinforced concrete, timber, etc.). It is usually a detached house with separate facilities and entrances for men and women and has a courtyard so that space is internally utilized.

Apartments. are generally found in buildings ranging in height from one to six stories,even though in later 
years buildings containing over ten stories are not unusual. Usualiy these units include an entry, a reception room or salon, bedroom(s), bathroom(s), familg/dining rooms. Up to the time of this writing, all apartments were rental type and there existed no ownership program of any sort, except for apartment building owners who lived in their own apartments.

Villas, are usually larger than other dwelling types. Construction utilizes modern materials (reinforced concrete, cement, etc.) They are usualiy more roomy and include separate sections for men and women.*

As part of the Jeddah Action Master Plan studies, a housing survey was conducted by Sert Jackson in 1978. A street block survey technique was utilized where the predominant condition of the block was recorded. Tables VII through IX illustrate the distribution of dwellings by type, age, and condition in Jeddah.

It should be noted that these findings are general in nature because a street block survey technique was utilized where the predominant condition of the block was recorded.

*In the Saudi Arabian culture, separation of socializing areas by sex is traditional. Due to the larger floor areas, villas and traditional housing would tend to accomodate that tradition more so than other housing types. 
TABLE VI

MONTHLY FAMILY INCOME IN RIYALS BY NATIONALITY FOR THE CITY OF JEDDAH

\begin{tabular}{|c|c|c|c|c|c|c|c|c|c|c|c|}
\hline Nationality & $\begin{array}{l}\text { Under } \\
\text { Number }\end{array}$ & $\begin{array}{c}1000 \\
\%\end{array}$ & $\begin{array}{l}1000- \\
\text { Number }\end{array}$ & $\begin{array}{c}1999 \\
\%\end{array}$ & $\begin{array}{l}2000- \\
\text { Number }\end{array}$ & $\begin{array}{c}4999 \\
\%\end{array}$ & $\begin{array}{l}5000- \\
\text { Number }\end{array}$ & $\begin{array}{c}9999 \\
\%\end{array}$ & $\begin{array}{c}\text { Over } \\
\text { Number }\end{array}$ & $\begin{array}{c}10,000 \\
\%\end{array}$ & Total \\
\hline Saudi Arabian & 2668 & 3.8 & 12259 & 17.5 & 31004 & 39.7 & 14260 & 20.4 & 7935 & 11.4 & 69874 \\
\hline Yemin1 & 3151 & 10.4 & :0695 & 15.4 & 11983 & 15.3 & 3128 & 10.3 & 667 & 2.2 & 30245 \\
\hline Palestinian & 207 & 1.2 & 2024 & 13.1 & 10212 & 13.1 & 3496 & 20.9 & 621 & 3.7 & 16767 \\
\hline Egyptian & 805 & 4.4 & 2622 & 14.5 & 9131 & 11.7 & 4761 & 26.3 & 782 & 4.3 & 18124 \\
\hline Others & 1495 & 80.2 & 5635 & 20.5 & 15824 & 20.2 & 10764 & 22.1 & 4209 & 79.4 & 38479 \\
\hline TOTAL & 8329 & 4.8 & 33235 & 19.2 & 78154 & 45.0 & 36409 & 21.0 & 14214 & 8.2 & \\
\hline
\end{tabular}

Source: Sert Jackson, 1979 
TABLE VII

DISTRIBUTION OF DWELLINGS BY TYPE IN JEDDAH, 1978

\begin{tabular}{lcc}
\hline Trpe of Dwelling & Number & Percentage \\
\hline Sandaga (Shanty) & 5290 & 3.0 \\
Arabic Traditional & 50968 & 29.4 \\
Villa & 13409 & 7.7 \\
Apartments & 93978 & 54.2 \\
Other & 9844 & 5.7 \\
\hline
\end{tabular}

Source: Sert-Jackson, Ltd., Socio Economic Survey (SertJackson, 1979, p. 114)

TABLE VIII

AGE OF DWELLINGS IN JEDDAH, 1978

\begin{tabular}{|c|c|c|c|c|c|c|}
\hline Age & Sandaga & Tradit. & Villa & Apt. & & Total \\
\hline & No. $\%$ & No. $\%$ & No. & No. & $\%$ & \\
\hline
\end{tabular}

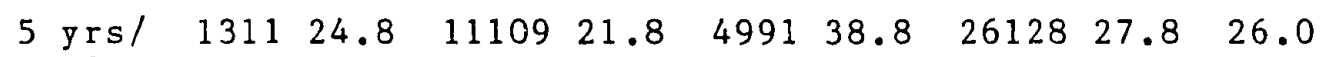
or less

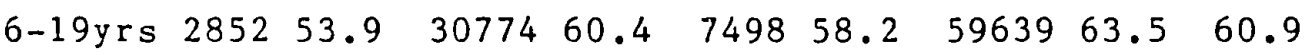

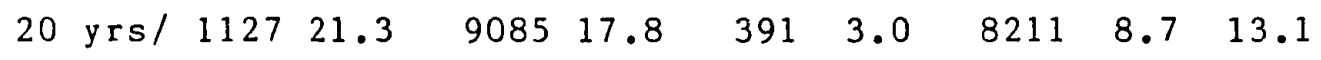

or more

Source: Sert-Jackson, Ltd.,(1979, p. 121) 
TABLE IX

CONDITION OF DWELLINGS IN JEDDAH, 1978

Building Type

Villas

Apartments

Traditional

All Buildings
Condition

$80 \%$ Good
$70 \%$ Good, $25 \%$ Fair, $5 \%$ Bad
$50 \%$ Fair, 30\% Bad
$50 \%$ Good, 30\% Fair, 20\% Bad

The ratings were based upon the follobing guidelines:

Bad: Structural defects and/or partial collapse

Misalignment of building (vertical or horizontal)

Non-permanent materials used in construction

Lack of vehicular access

Lack of privacy due to extreme proximity (windows within two meters of each other)

Fair: Defects in non-structural materials of the building, including windows and doors

Good: None of the above defects.

Source: Sert-Jackson, (1979, p. 199)

Finally, the tenure status of housing in Jeddah changed substantially from 1971 to 1978 as indicated below. The Sáüi Arabian government dôes not allow non-Saudis to owin property, and the above figures apply to the whole city. Survey results indicate a 40 percent ownership rate for Saudi households in 1978, which is an improvement over 
1971. However, approximately 50 percent of Saudi households rent their dwellings (Sert-Jackson, 1979). The main reason for this relatively high rate is the high cost of home ownership. This issue will be discussed later.

TABLE X

TENURE IN JEDDAH, 1971 VERSUS 1978

\begin{tabular}{lrr}
\hline Tenure & 1971 & 1978 \\
\hline & & \\
Own house & $30.8 \%$ & $18.6 \%$ \\
Rent & $64.5 \%$ & $76.9 \%$ \\
Other (company & $4.7 \%$ & $4.5 \%$ \\
$\begin{array}{l}\text { compounds, relative's } \\
\text { homes, etc. }\end{array}$ & \\
\hline
\end{tabular}

Source: Sert-Jackson (1979, figure 6.13)

The above results were for all nationalities. Ownership rates among Saudis were found to be approximately 40 percent in 1978 .

Housing Sector Problems

The five-year development plans. as reviewed earlier, led to an expansion in the economy for which many sectors in the economy were unprepared. The housing sector, which includes builders, real estate agents, financiers, and local government officials, was incapable of accomodating the increases in demand for housing in a very short time span. The increases in demand, as identified in earlier sections, were due to the following: 
1. An increase in the urban population due to the in-migration of foreign workers as well as rural inhabitants who migrated toward the cities;

2. An increase in income and wealth leading to an increase in the demand for quality dwellings.

3. A general lack of investment portfolio instruments beyond real estate. This element was coupled with the tremendous returns on real estate that exceeded even foreign investment instruments.

Land

One of the main data problems in this category is that land ownership was not codified into a system which clearly defined property rights (according to findings by SCET 1975, pp II-1,11). Local government municipalities were not able to effectively regulate land uses due to the existence of "unquestionable land use" situations, i.e. the use of land was up to its individual owner. Growing land speculation especially close to the urban center led to an increasing demand for the usually less expensive outlying areas. This effect was catalyzed by declining transportation cost (10w gasoline prices and low import duties on automobiles). Provision of infrastructure became a prominent problem during the early and middle 1970s. 
Infrastructure was viewed as the government's responsibility and the government did substantial work in that area, but "capital improvement programming" was weak or nonexistent, i.e., the timing of infrastructural work was difficult both in terns if sequencing and balancing. The growth of cities was not well planned or coordinated.* As an illustration of city growth, Jeddah had a growth pattern as follows:

TABLE XI

GROWTH OF THE CITY OF JEDDAH

\begin{tabular}{|c|c|c|}
\hline Year & Area (hectares) & Population \\
\hline 1947 & 63 & 40,000 \\
\hline 1971 & 4750 & 381,000 \\
\hline 1980 & 9700 & $1,037,000$ \\
\hline
\end{tabular}

Source: Sert Jackson (1980, p. 3)

Land values were on the rise despite an increase in the supply of developable land. Centrally located land and land along transport corridors usually demanded higher prices. As an example, land prices in the central business district (the heart of downtown) in Jeddah were approximately 6000 riyals per square meter in 1971. In 1975 they reached 12,000

*The "crazy quilt" pattern was especially evident in the capital city of Riyadh. 
riyals per square meter and in 1980 they were estimated at 32,500 riyals.* (Sert-Jackson, 1980).

Since 1980, prices of land appear to have been declining in general, partly due to the expanding land supply

Labor

As mentioned earlier, the indigenous work force was incapable of executing the deveiopment plans without assistance. This was due to several reasons:

The qualitative requirements of the development projects were also mismatched to the available work force not only for professional white collar jobs, but also for skilled, semi-skilled, and unskilled blue collar jobs. Additionally, a reduction in employment participation rates occurred during 1970-1980 for the younger Saudis (12-19 year-olds) and the older ones (over 60 years). The former dropped from 37 percent of the work force in 1975 to 21 percent in 1980 , most probably due to the availability of education and manpower training programs. The latter dropped from 51 percent to 46 percent of the work force from 1975 to 1980 respectively. (Ministry of Planning, 1980, p. 37). This drop was probably due to the increasing wealth in the country. The Saudi indigenous *These estimates were based upon interviews with real estate agents, private developers, and municipality personnel. 
working population declined from 72 percent to 57 percent of the total work force over the periods 1970-75 to 197580. This reduction was indicative of the increase in the size of the work force rather than the deciining participation rates. Table XII illustrates the magnitude of foreign labor needs. It should be noted that the figures actually understate the foreign labor presence because non-resident workers may be on "short" duration stay or they may be illegal aliens.

TABLE XII

RESIDENCE PERMITS ISSUED TO FOREIGNERS, RINGDOMWIDE

$\begin{array}{lllllll}\text { Year } & 1976 & 1977 & 1978 & 1979 & 1980 & 1981\end{array}$

No. $\quad 424,227 \quad 522,085 \quad 606,403 \quad 687,274 \quad 668,931632,156$

Source: Central Department of Statistics, 1981.

Overall employment grew at ẩ average annual rate of 3.8 percent over the period (1975-80) from a total of $1,328,000$ in 1970 to $1,600,000$ in 1975. The rate of growth of the work force during the period of the second development plan was approximately 7.2 percent from $1,746,500$ in 1975 to $2,471,200$ in 1980, (Ministry of Planning, 1980, p. 37) The average annual growth rate for 
employment in the construction sector was almost 25 percent from 1970 to $1975--$ from 141,500 to 314,200 . From 1975 to 1980 the average annual employment growth in construction was 13.3 percent (Ministry of Planning, 1976; 1980).

Data regarding proportions of Saudis to non-Saudis by sectors was not available. However, it was expressed in several interviews that the construction sector had a very substantial proportion of foreign labor whereas sectors such as agriculture and general services had lower foreign proportions.

Finally, Saudi labor unemployment was recorded as low as 2 percent in Jeddah in 1978 (Sert Jackson, 1979). This low figure is probably typical of other large urban areas.

\section{Materials}

The increase in demand for building materials led to delivery bottlenecks both for locally produced materials and for imported ones. Most of the construction material-primarily cement, steel reinforcing bars, aggregates, lumber, etc.--was imported. The constraint in this case was mainly the port system and the road capacity and ability to deliver materials once unloaded in the ports. Table XIII below indicates the rate of growth of three key building materials imported from 1970-1980.

The Kingdom's main ports of Jeddah and Dammam could 
not handle the increasing cargo volumes until 1975-76 when ports productivity more than doubled allowing for relief of these constraints on all imported goods including building materials.

\section{TABLE XIII}

GROWTH RATE OF MAIN BUILDING MATERIAL IMPORTS RINGDOMWIDE (1969-1980)

\begin{tabular}{lccc}
\hline Year & Iron and Steel & Cement & Lumber and Products \\
\hline 1969 & 100 & 100 & 100 \\
1970 & 95.9 & 76.2 & 86.8 \\
1971 & 123.8 & 91.8 & 110.6 \\
1972 & 153.9 & 55.6 & 106.0 \\
1973 & 208.6 & 78.4 & 195.8 \\
1974 & 340.9 & 291.1 & 294.8 \\
1975 & 418.1 & 268.7 & 490.4 \\
1976 & 1204.0 & 933.9 & 2082.8 \\
1977 & 2444.3 & 2214.7 & 2909.3 \\
1978 & 2992.7 & 2396.7 & 2804.8 \\
1979 & 4189.7 & 2277.2 & 3170.1 \\
1980 & 4629.5 & 3391.5 & 3533.4 \\
\hline
\end{tabular}

Source: Central Department of Statistics, 1981

The main building material, cement, was produced nationally by five privately owned companies: The Arab Cement Co. (Jeddah), the Saudi Cement Co. (Hofuf), the 
Yamamah Cement Co. (Riyadh), the Quassim Cement Co. (Quassim), and the Saudi Bahraini Cement Co. (Dammam). These companies were expected to produce a combined output of 32.0 million metric tons of cement over the period 198085. This represents about 47 percent of the total cement requirements for that time period as estimated by the Ministry of Planning (Ministry of Planning, 1980, p. 261), based upon projected construction activity.

\section{Capital}

Before the late 1930s, banking activities were Iimited to short term financing of imports, financing of local serviceoriented business, and accepting deposits (Nyrop, 1977, p. 226). In addition to banks, a few money changers operated primarily to handle foreign currency changes. In 1952, the Saudi Arabian Monetary Agency (SAMA) was formed. This agency was to be the Saudi equivalent of a central bank. Its functions included regulation of banking, issuance and stabilization of currency, and general implemention of the Ringdom's monetary policy. The country's general business environment, which has traditionally centered on free enterprise, encouraged banks to participate in the Kingdom's development. In 1975, there were ten foreign banks operating in the Ringdom in addition to two local banks. These twelve banks had 79 
branches throughout the Kingdom (Ministry of Planning, 1980, pp. 2723). In 1975, a "Saudization" program was initiated by which the Saudi public could participate in the banking sector. Only banks that were half owned by the Saudi public could open additional branches. This led to the "Saudization" of foreign banks, i.e. public corporations were formed and half the shares were sold to the public.

As oil revenues and the consequent government spending increased in the mid 1970s, lending aciivity did not exhibit a growth rate that was commensurate with the overall economic development of the economy. This may be attributable to several reasons:

(1) The economy had a massive inflow of assets thus making the perceived need for credit small during the earlier years.

(2) The highest law in the Kingdom, Islamic law, disagreed with the use of conventional interest bearing loans including interest bearing mortgages.* Banks thus embarked upon "fee schedule systems" that served in lieu of interest.

*In 1981 the Ministry of Justice ruled that interest
bearing mortgages were a violation of Islamic law
(Institutional Investor, November 1982).


(3) The "Banking Control Law" issued by Royal Decree (M/5, 1966) specifically prohibited banks from acquiring or leasing real estate except as necessary to conduct their own businesses and to house their own employees. If a bank acquired real estate to satisfy debts due, the bank had to dispose of it within three years...(Ministry of Finance, 1978, Article 10). The point here is that banks had no incentive to grant longer term loans, especially for housing, since they could not hold real estate as long term assets.

(4) The banking sector, just as in other sectors, was unprepared for the sudden economic growth. Constraints on manpower, space, and know how made it difficult for the banking sector to respond fully to the greater demand for the medium and long term borrowing which emerged in the middle and 1 ate 1970 s.

On the other hand, the demand for credit was satisfied by specialized government credit institutions, one of which specialized in long-term housing finance and will be discussed in the next chapter.

As shown in Table XIV, the loan growth rate averaged a strong 47.8 percent, however, recent interviews with several banking officials indicated that long-term loans 
were a verg small proportion of total loans and that longterm loans for home purchases were practically nonexistent.

The building and construction sector accounted for up to 22 percent of the bank credit in the late 1970s (Saudi Arabian Monetary Agency, 1981).

Building and construction technology was identified as a problem area, but not as important as the other bottlenecks mentioned.

TABLE XIV

LOAN GROWTH RATE, KINGDOMWIDE

End of Hijra Year Loans(in Millions Percent Growth Rate

\begin{tabular}{rrr}
\hline 1391 & 1694 & - \\
1392 & 1715 & $1.2 \%$ \\
1393 & 2283 & $33.1 \%$ \\
1394 & 4410 & $93.2 \%$ \\
1395 & 6512 & $47.7 \%$ \\
1396 & 9368 & $48.0 \%$ \\
1397 & 9714 & $0.8 \%$ \\
1398 & 13951 & $43.6 \%$ \\
1399 & 25054 & $9.6 \%$ \\
1400 & 34199 & $36.5 \%$ \\
\hline
\end{tabular}

Source: Central Department of Statistics, 1981 


\section{SUMMARY}

Several problem areas have been identified that directly impacted the housing sector. The requirements of the development plans induced changes in the demographic composition of urban areas. An inflow of migrants from within the country and abroad led to unprecederted growth patterns. This in turn led to increasing demands for living space, the supply of which encountered bottlenecks in land delivery, labor, building material, and capital. The situation was exacerbated by the unavalability of enough financial instruments to reduce speculative practices in real estate.

The context for Saudi housing policy was established. On the one hand, a socio-economic development framework to guide policy was identified in the Five Year Development Plans. On the other hand, a plethora of housing sector problems that needed to be solved were identified. 
CHAPTER IV

THE SAUDI ARABIAN HOUSING POLICY

\section{Introduction}

This chapter will start with the explicitly stated housing policy elements. The housing goal, objectives-including numerical supply and demand estimates, and criteria--will be discussed. The achievements of the individual policy elements in terms of "general" housing criteria will be reviewed first, i.e. the extent to which each policy element has been attained supplying housing units and/or in bringing housing prices down.

The Housing Policy Elements

The Goal

The Saudi Arabian housing goal was expressed as enabling "...every household in the kingdom to have a decent, safe, and sanitary dwelling of a standard consistent with its level of income." (Ministry of Planning, 1976, p. 510). Even though there was no explicit timeline given, it may be assumed that the timeliness of the goal was crucial, especially that at its time of formulation a housing crisis was perceived to exist. 
The Objectives

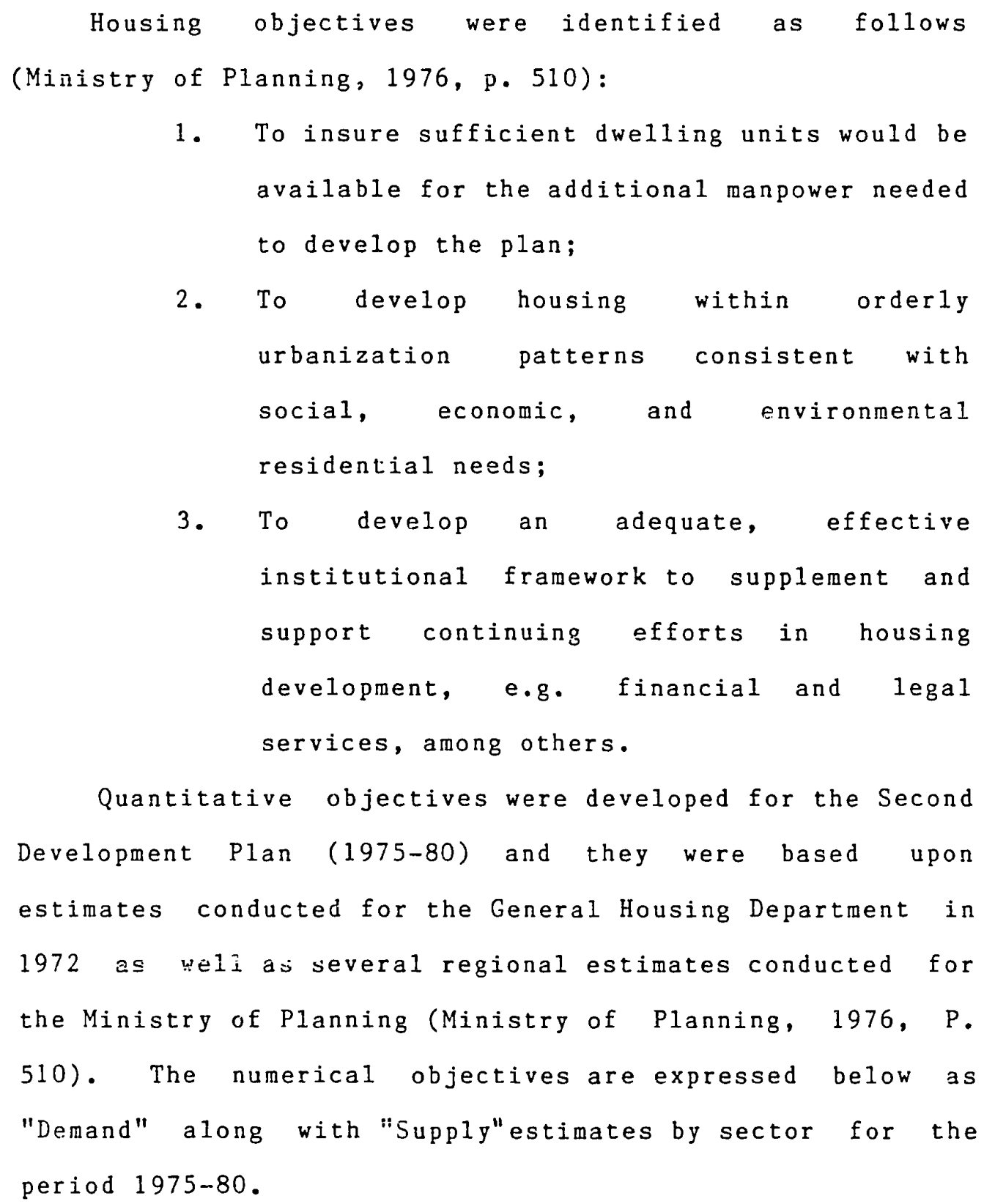

The 117.0 thousand units listed under demand as substandard or dilapidated were not included as pivotal to 
housing need for the plan period. Those units were just 1 isted as candidates for replacement.

TABLE XV

ESTIMATED HOUSING NEED AND SUPPLY 1975-80

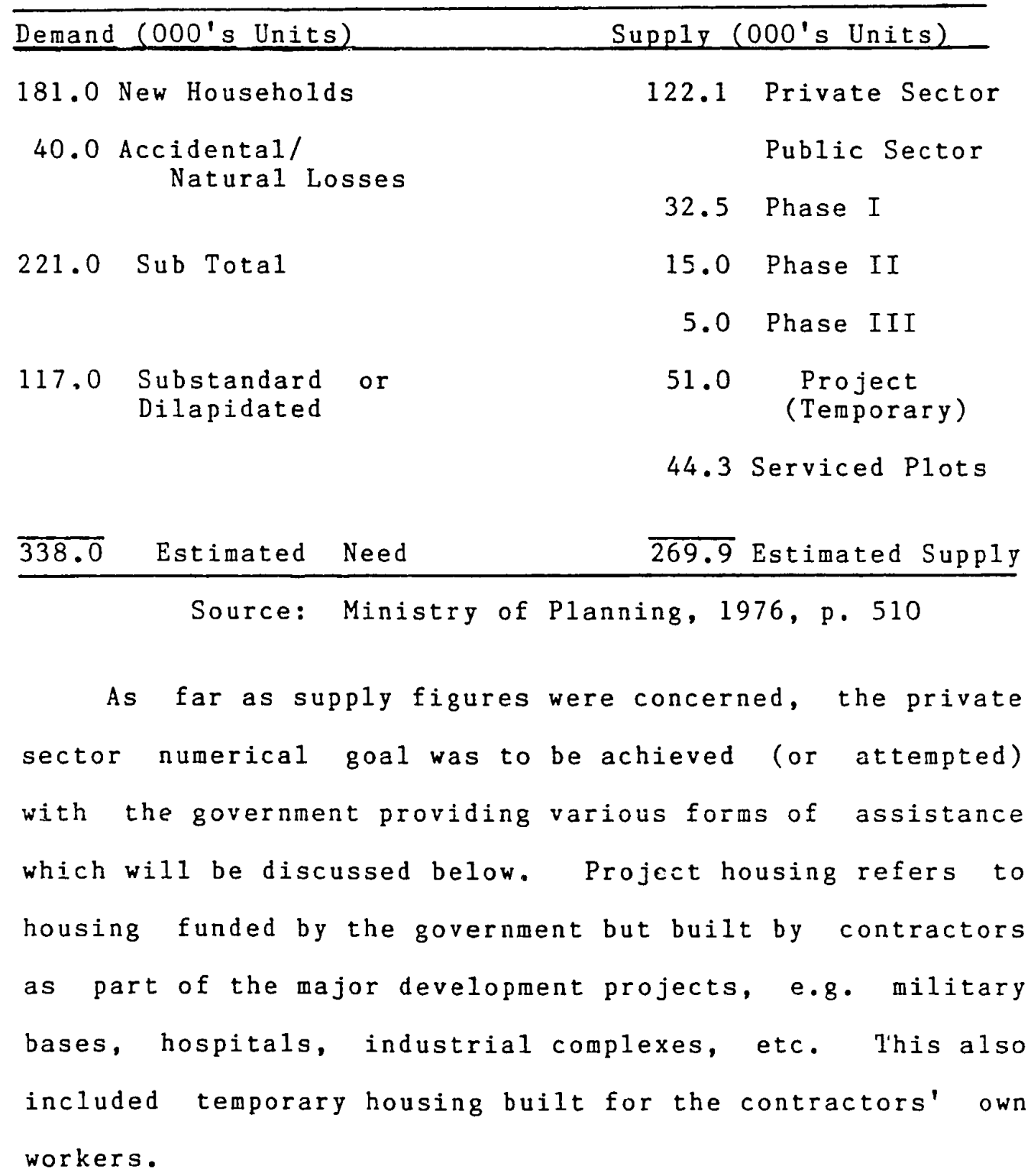




\section{Criteria*}

The Second Development Plan (1975-80) included specific criteria for the housing programs. The criteria are summarized below:

1. The Pub1ic Housing C1ientelle:

a. Efforts were to focus on low and moderate income households with target home ownership rate of 75 percent.

b. The housing income burden ( $p l u s$ utilities) was not to exceed 25 percent of income for low and moderate income groups, whether for loan repayment or rent.

c. No illegal evictions were to be allowed.

d. Conformity with government tenure agreements would be required for all government assisted dwellings.

e. Income reviews of the clientelle would be conducted to insure proper service provisions.

f. Loss of head of household earner would be insured through the government.

2. Housing Standards:

a. All publicly financed or built housing would be

* Sources: Second development Plan (1975-80) pp. 510-1 and interviews with various officials. 
standard or better quality and built in residential subdivisions.

b. Al1 subdivisions would conform to city planning regulations.

\section{Location:}

Areas of stable employment and a high demand for housing in urban areas were the conditions chosen for locating public housing.

4. Finance:

a. For privately built housing, the source of financing was to be the Real Estate Development Fund, starting with 10 percent of the homes privately built in $1976-77$ and increasing to 50 percent in 1980 .

b. Public housing was to be financed through public funds, income from rents, loan repayments, and leasing agreements.

c. Estimates of funds requirements were expressed as follows (Ministry of Planning, 1976, p. 518):

Program Cost (Riya1s)

Private Sector Assistance $\quad 5140.0$ million

Public Sector Housing $\quad 7350$ million

Public Sector Plots 1722 million

5. Housing Services

Housing services were identified in a very 
broadly as providing households with technical and legal advice relaced to the purchase, rental, and maintainence of their homes.

6. Institutional Arrangements: Four basic institutional changes were made explicit:

a. The General Housing Department--which up to 1975 was part of the Ministry of Finance--was to be strengthened to become the Ministry of Housing with greater authority, responsibility, and budget to implement the public housing programs through regional offices. A financing organization was to be created to handle the financing needs for private sector housing.

b. Encouragement of the private sector construction activity to ease entry into the housing sector in order to increase housing production.

c. Development of a general "insurance Fund" to cover loss of head of household or accidental destruction of structure.

Several comments regarding the above are in order:

There existed no guidelines for defining income limits to separate low and moderate income groups from others. There was no historical precedent for "hire purchase" or installment agreement contracts. Finally, no mention was made regarding provisions for manpower 
shortages, e.g. the General Housing Department had a staff of about ten people, of which only two were at the managerial level and the rest were technically oriented (SCET, 1975, p. A-VI-2) The manpower bottlenecks were just as serious in the public as they were in the private sector (which was briefly discussed above.)

Housing Achievements

Public Housing

The General Housing Department was strengthened and restructured to become the Ministry of Housing in 1975 (Nyrop, 1977). Table XII illustrates the type, magnitude, and status of the Ministry's public housing projects. Compared with numerical targets specified earlier, public housing efforts have achieved approximately one third of its 52500 units goal. This result is based upon the actual completed units and the units in process, but exclude abandoned units, i.e. 12388 (complete and in process) + 5041 (in process) $\div 52500$ (original plan target over three phases) $=33.2$ percent Achievement rate.

Unfortunately, the results understate the problem. By the end of 1983 all public housing units were vacant, some since 1979 .

The following is a brief description of the individual public housing projects: 
TABLE XVI

PUBLIC HOUSING PROJECT SUMMARY

\begin{tabular}{|c|c|c|c|}
\hline \multirow{2}{*}{$\begin{array}{l}\text { PROJECT (LOCATION) } \\
\text { Existing Projects }\end{array}$} & \multirow[t]{2}{*}{ NO, UNITS } & \multicolumn{2}{|c|}{$\begin{array}{l}\text { START/FINISH } \\
\text { DATES }\end{array}$} \\
\hline & & & \\
\hline $\begin{array}{l}\text { 1. Low Income Housing } \\
\text { "Candilis"(Jeddah, } \\
\text { Riyadh, Dammam) }\end{array}$ & $3250 *$ & Abandoned & $1973 /-$ \\
\hline $\begin{array}{l}\text { 2. "Rush" Housing } \\
\text { (Jeddah) }\end{array}$ & 1996 & Complete/Vacant & $1977 / 79$ \\
\hline (Riyadh) & 1152 & Complete/Vacant & $1977 / 82$ \\
\hline (Dammam) & 1664 & Complete/Vacant & $1977 / 79$ \\
\hline $\begin{array}{l}\text { 3. "General" Housing } \\
\text { (Jeddah) }\end{array}$ & 3420 & Complete/Vacant & $1979 / 83$ \\
\hline (Riyadh) & 5041 & In process & $1978 /$ \\
\hline (Al-Khobar) & 4106 & Complete/Vacant & $1978 /$ \\
\hline
\end{tabular}

TOTAL UNITS: 12,338 units excludes in process and abandoned units.

New Projects

$\begin{array}{lrll}\text { 1. Riyadh (3. Sharq) } & 1258 & \text { In Process } & 1982 / 36 \text { mo. } \\ \text { " (Land Development) } & 1956 & \text { In Process } & 1982 / 36 \text { mo. } \\ \text { 2. Mecca } & 2592 & \text { Not Started } & \\ \text { 3. Medina } & 2084 & \text { In Process } & 1982 \\ \text { 4. Biraidah } & 949 & \text { In Process } & 1982 \\ \text { " (Land Development) } & 1649 & \text { In Process } & 1982\end{array}$

TOTAL: 6,883 units plus 3,631 developed plots.

Source: Ministry of Housing, interviews (1983)
*Information regarding this early project was obtained
from the report by SCET International (1975) and local
interviews. Information may not be as accurate as it is
for more recent projects.


1. The First Low Income Housing Program of 1973*

This program involved 3250 to 3500 units to be built in the major urban centers (Jeddah, Riyadh, Dammam, and Alkhobar) specifically for low income households. The projects involved using local contractors to build concrete structures in a flexible design so that inside walls may be removed to add space. The units were very small (80 to 120 meters) and built in a high density arrangement. This project was unfortunately plagued by land disputes, i.e. individuals claimed that part of the project site was theirs; another problem was the lack of utility lines in the areas chosen; and finally, several problems with workmanship were mentioned.* Due to increasing costs, as well as certain contractual ambiguities, the project is unfinished and abandoried.

This program was authorized when housing was the responsibility of the Ministry of Finance (through the General Housing Department) and this was mentioned as a problem. According to one interviewee, the project falls outside the direct area of responsibility of the Ministry of Housing. However, in 1979 the Council of

* In the city of Jeddah, this was known as the Candilis/Aboul Foutooh project because of the contractor's name.

\footnotetext{
* These problem areas were identified through interviews with various Ministry of Housing personnel. private consultants, and $\operatorname{SCET}$ (1975, p. A-VI-5).
} 
Ministers authorized the Ministry of Housing to supervise the completion of these projects (Al Moheet Al Saudi, November 64,1980$)$.

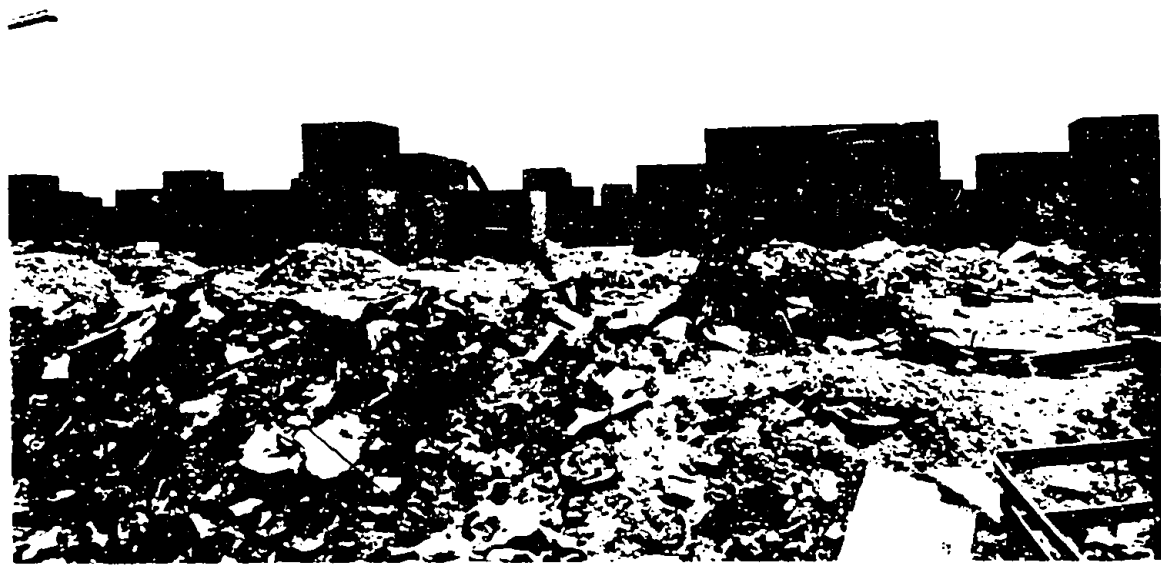

Figure 5. The Abandoned Candilis Project, Jeddah (1983)

2. The Rush Housing Project of 1977

During 1975, housing was recognized as a major constraint to the implementation of the Second Development Plan (1975-80). Specifically, foreign high and medium qualified personnel were viewed as one of the primary clientelle for new housing units (SCET, 1975, p. I-1).* Many Saudi households were also viewed as a primary clientele that created a need for quality, durable housing.

*Unskilled blue collar workers were considered to be tolerant of temporary housing arrangements such as barracks and shacks. 
Severe shortages in the building sector and the housing sector were experienced. This led to increasing prices as well as a "filtering up" phenomenon, i.e. Saudi households were being displaced by foreign workers who were able to outbid them for the better housing units. A need was thus felt for an accelerated housing program. The demand support approach was considered to be inappropriate because of the existing bottlenecks in the market. A supply support strategy involving a rush (or crash) housing program which was to satisfy the following requirements:

a. high quality, well constructed units

b. the shortest possible construction time

c. the least amount of disruption to the local housing sectors

d. immediate access to utilities

e. assuring comfort, privacy, security, and the Islamic way of life

The Ministry of Housing embarked upon the ambitious project of constructing 1936 units in Jeddah, 1152 units in Riyadh, and 1664 units in Dammam, "as soon as possible, without compromising quality." (Al Benaa, 1979) The projects were initiated around 1977 and the common unified design was drawn in France (with Saudi coordination). The requirement of immediate access to utilities necessitated locating within the urban periphery resulting in a high-rise design. The living units included three bedroom, 
and three bathroom, spacious ( 220 square meter) units. The design involved a platform upon which four eight-story "towers" were constructed. Each tower was complete with four elevators and four apartment units per story, a helicopter landing pad on top of every "tower" and a fully equipped bomb shelter. Construction was completed in 23 months (for the Jeddah project). Figures 5 and 6 below illustrate the platform-tower design.

It should be noted here that the cost of these "Rush" projects was phenomenal. Several issues seemed to have contributed to that:

a. the speed with which construction was completed;

b. the importation of almost all construction materials;

c. the high quality of the buildings;

d. the fact that the contractors and consultants were European (as opposed to the expensive far eastern consultant and contractors).

The cost per unit was approximately 2106 million riyals for the 1936 apartment units in Jeddah. Cost data for the other two Rush Housing Projects in Riyadh and Dammam is not available, however it is not unreasonable Lo assume that they were compardbly expensive. It should also be noted that the cost given above excludes land costs 
which were also expensive. The Jeddah project, for example, occupied slightly under fifteen hectares on one of the main arterials within the city.
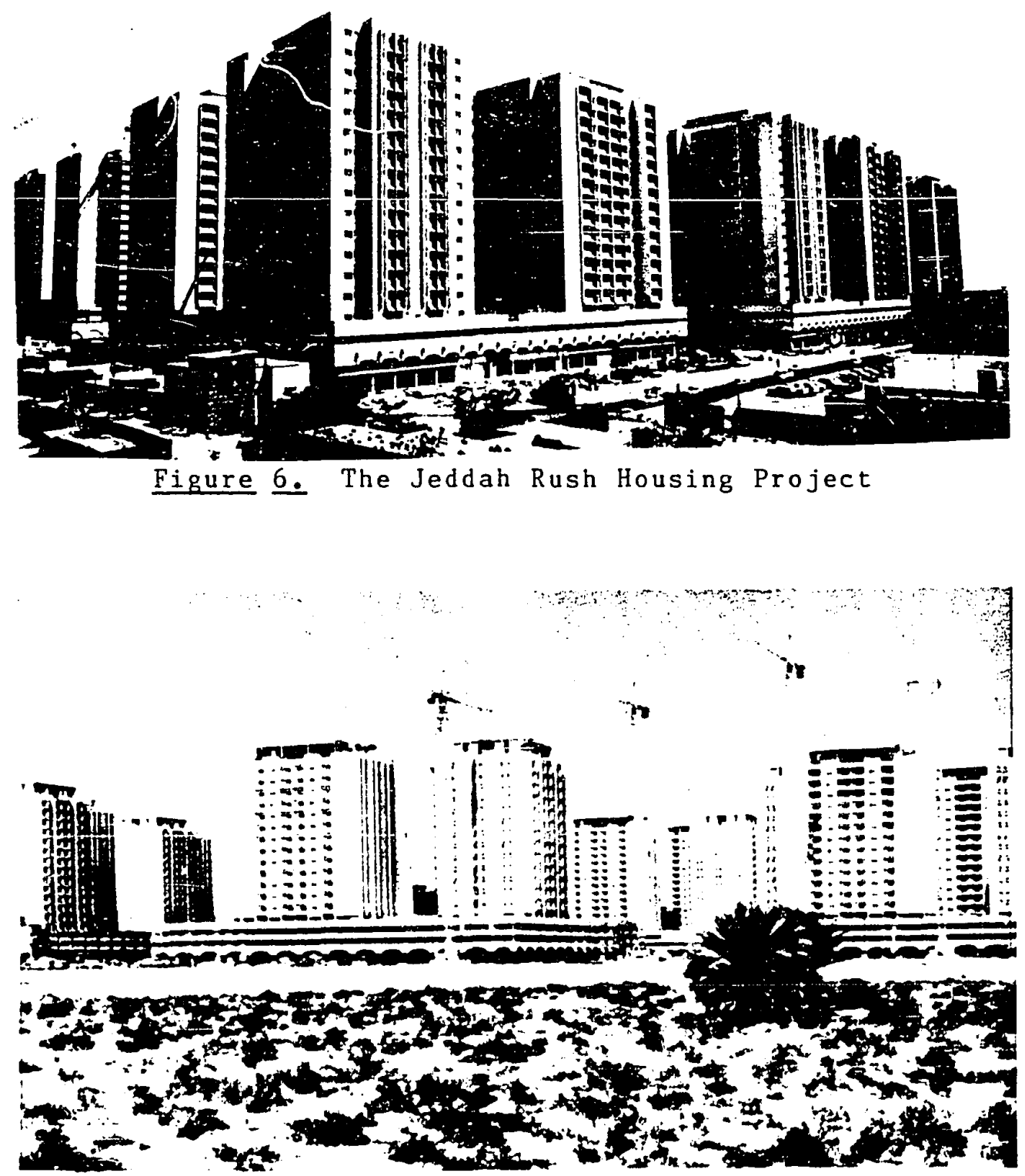

Figure 7. The Dammam Rush Housing Project 


\section{The General Housing Projects}

This project was unlike the Rush Housing in that it did not require an accelerated program of construction. It also did not necessitate the availability of pre-existing utility hook-ups and land availability was not as constrained as was the case for Rush Housing. The same basic design was utilized for apartments, but because of the relatively greater amount of land available, villas (detached single family dwellings) were also built in the Riyadh Project. The former units were about $220 \mathrm{~m}$, the latter $400 \mathrm{~m}^{2}$. The "general housing project" was also differenc in that it was located outside of the city periphery and it was to be based upon the neighborhood unit, i.e., - schools, shops, hospitals, and other basic services were provided in the major projects. A significant difference between this project and Rush Housing is cost. Not only was the time frame not rushed, but construction utilized building materials available from local markets, i.e., less expensive locai resources. Additionally, the contractors working on the projects themselves were from the far east (Korea) which were less expensive than the European contractors of the "Rush" project. Finally, it should be noted that the General Housing Projects were initiated after the Rush Housing

* The General Housing Projects still utilized European consultants. 
Projecis, which reduced design and/or administrative errors. The cost for the Jeddah General Housing Project was still substantial at 1700 million riyals for the 3420 units (excluding land).

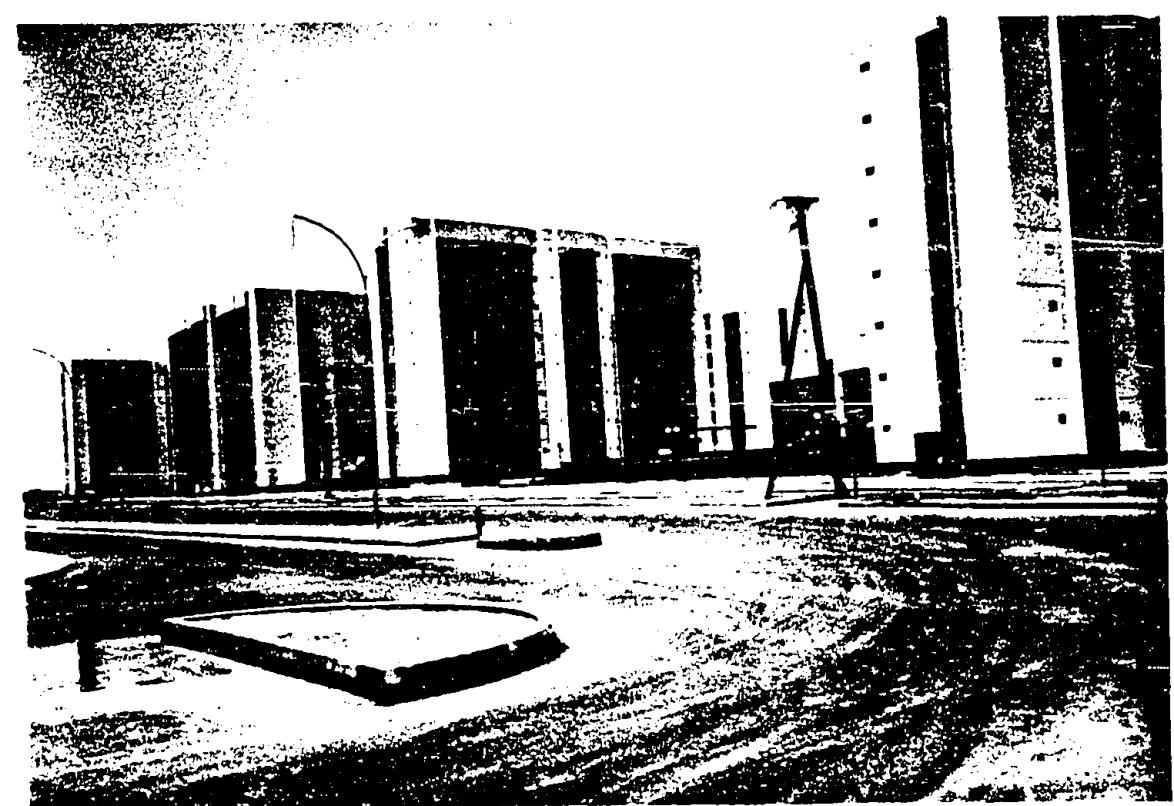

Figure 8. The General Housing Project, Jeddah

\section{Finance}

As mentioned earlier in discussing The Second Plan's housing goals, a new agency was to be formed to handle financing of private sector home building. The Real Estate Development Fund, REDF, was authorized in 1394 A.H. (1974 A.D.) and started operation in 1975. It is a financial lending institution under the Ministry of Finance and National Economy. Its administration consists of a president, nominated by the Minister of Finance, and seven members-four from the Ministries of Finance, Housing and 
Public Works, Planning, Municipal and Rural Affairs; and three members from the Saudi Public. In 1981/82 there were two hundred and seventy employees, 68 percent in financial and administrative departments, 16 percent in technical depazidists, and 16 percent in various other areas. (REDF, 1983)

The REDF aims at helping to fulfill the Kingdom's quantitative and qualitative housing needs by provision of two types of loans:

(1) Private Loans: Primarily targeted at low- and middle-income landowners for private housing construction. Loans do not exceed 70 percent of new housing cost or 300,000 riyals. Loans are long term ( 25 years) and interest free (later becoming negative interest).

(2) Investment Loans: Provide landowners with interest free loans for multi-unit investment quality projects. Loans do not exceed 50 percent of the unit cost with an upper limit of 10 million riyals.

The Procedure by which loans are granted involves the following:*

a. Providing proof of Saudi citizenship (only nationals were eligible)

* Sources: Loan applications and interviews with REDF officials. 
b. Proof of land ownership (land deed was to be held as collateral)

c. Building permit and approved design plats from the local municipality

d. Approval of the technical department of the REDF in the submitted plats

e. For personal loans an advance payment of 10 percent was to be made, followed by successive payments as construction progressed. Four payments were to be provided in total for the 70 percent or 300,000 riyals.

f. For investment loans, the same basic procedure applied, except that no advance payment was to be made and a total of five equal payments were to be advanced to the borrower, each after the completion of certain construction stages. Additionally, specific building specifications defined by the REDF technical department were to be met in order to receive payments. These involved floor area, setbacks, entryways, utility hookups, structural requirements, etc.

Achievements. Tables XVIII and XIX illustrate the tremendous growth in the capital of the REDF as well as the lending activity over the period $1975 / 76$ to $1981 / 82$.

*Sources: REDF interviews and official application materials. 
TABLE XVII

REDF CAPITAL AND INVESTMENT LOAN GROWTH

Source: REDF 1983

\begin{tabular}{|c|c|c|c|c|c|}
\hline $\begin{array}{l}\text { FISCAL } \\
\text { YEAR }\end{array}$ & $\begin{array}{r}\text { CA } \\
\text { AUTHOR IZED }\end{array}$ & $\begin{array}{l}\text { PITAL* } \\
\text { PAID UP }\end{array}$ & \# OF LOANS & US ING & REPAYMENT** \\
\hline $1975 / 76$ & 9000 & 5000 & - & - & - \\
\hline $1976 / 77$ & 23800 & 10502 & 439 & 8223 & 1 \\
\hline $1977 / 78$ & 33800 & 19900 & 139 & 2043 & 10 \\
\hline $1978 / 79$ & 33800 & 24900 & 419 & 4534 & 55 \\
\hline $1979 / 80$ & 38800 & 30850 & 287 & 2276 & 91 \\
\hline $1980 / 81$ & 43800 & 38850 & 202 & 1738 & 112 \\
\hline $1981 / 82$ & 51100 & 43850 & 196 & 1546 & 174 \\
\hline & REDF & $\begin{array}{l}\text { TABLE } \\
\text { PRIVATE LOAN } \\
\text { Source: }\end{array}$ & $\begin{array}{l}\text { XVIII } \\
\text { N DISBURSEM } \\
\text { REDF } 1983\end{array}$ & ENTS & \\
\hline $\begin{array}{l}\text { FISCAL } \\
\text { YEAR } \\
\end{array}$ & $\begin{array}{c}\text { APPLI- } \\
\text { CATIONS } \\
\end{array}$ & $\begin{array}{l}\text { DISBURSE- } \\
\text { MENTS }\end{array}$ & VALUE* & $\begin{array}{l}\text { REPAY - } \\
\text { MENTS ** }\end{array}$ & $\begin{array}{c}\text { HOUSING } \\
\text { UNITS BUIT }\end{array}$ \\
\hline $1975 / 76$ & 34189 & 34189 & 8197 & 13 & 41027 \\
\hline $1976 / 77$ & 46955 & 46955 & 13536 & 66 & 56347 \\
\hline $1977 / 78$ & 30700 & 3832 & 955 & 221 & 4598 \\
\hline $1978 / 79$ & 35303 & 34407 & 8690 & 437 & 41288 \\
\hline $1979 / 80$ & 37016 & 33190 & 8185 & 1115 & 39828 \\
\hline $1980 / 81$ & 36815 & 28593 & 6956 & 1070 & 34312 \\
\hline $1981 / 82$ & 35572 & 31133 & 8052 & 1418 & 37360 \\
\hline
\end{tabular}

* All values are in millions of Saudi Riyals.

* These figures refer tc early repayment. 
The sources of capital for the REDF are Saudi government allocations as well as loan repayments. Operational funds mostly account for banking services (expenses). In $1981 / 82$ these funds reached 106 million riyals ( 40 million of which were for banking expenses).

The personal loans were long term ( 25 years) with a two-year grace period. In 1980, two types of repayment incentives were enacted. The first was an on-time payment discount which rewarded borrowers who pay within one month of their due date with a 20 percent reduction of their installment. The second was an early payment discount of 10 percent, i.e., the loan principal was to be reduced by 10 percent if the entire loan was to be paid early. Investment loans were initially to be repaid within five years and they had a ceiling amount of 15 million riyals. In 1978 the ceiling was reduced to 10 million riyals, but the repayment period was extended to ten years. Investment loans were not limited to the construction of dwelling units, but also included office and exhibition (commercial) space. The actual efficiency in terms of dwelling units per loaned riyal was 20360 (units) $\div 3299$ (million riyals) $=6.17$ units per million riyal loaned. This figure was higher than for personal loans where the efficiency was 254,759 (units) $\div 54,571$ (million riyals) = 4.67 units per million riyal loaned. (These figures do not take into account the fact that a greater proportion of the 
loan was needed in cash for the investment type loan (50 percent) versus ( 30 percent) for constructing private dwelling units.)

The loans indicated in the table were for the Kingdom's urban and rural areas combined. In 1981, an amendment was enacted that limited the riyal value of personal loans to 200,000 riyals for small villazes and rural areas; 250,000 riyals for medium sized towns; and 300,000 riyals for major cities.

As the tables indicate, there was a reduction in the number and value of investment loans beginning in 1979 due to the feeling by the REDF that the supply of housing complexes, office buildings, and commercial space was becoming abundant enough to warrant a reduction. On the other hand, an explanation for the sudden decline in private housing loan disbursements from 46,955 loans in $1976 / 77$ to 4598 in $1977 / 78$ (a drop of over 90 percent) was not directly available. The drop--it may be inferred--was not due to a lessened demand for loans, which was not weak at 30,700 applications in the fiscal year $1977 / 78$.

Up to 1979, it was expressed that no coordination existed between the REDF and other building sector elements such as the Ministry of Housing and the Real Estate Development Co. and the Municipalities, etc. (Al Benaa, 1979, p. $8 \overline{9})$. However, the REDF utilized the assistance of the two largest local private banks (The 
(The Riyadh Bank and The National Commercial Bank) whose branches throughout the Kingdom assisted in the loan provision as underwriters.

\section{The Saudi Real Estate Company}

This company was formed by a Royal Decree in 1976 with the following general goals: (SREC, p. 9, undated)

1. To help satisfy the demand for residential and comercial space through construction;

2. To conduct basic studies to improve building efficiency and consequently to achieve higher returns in real estate investments made by the Company; and

3. To work toward ensuring availability of basic materials and equipment for building in order to avoid shortages of these materials which occur in the local markets.

The capital of the company was set at 600,000,000 (six hundred million) riyals divided into six million shares of equal value (100 riyals) and owned by (Saudi Read Estate Co. Document, undated):

o The Social Insurance Organization

- The Public Investment Fund

- The Pensions Department

o The Riyadh Bank

- The National Commercial Bank 
- Private Shareholders (2076 individuals) own percent of the stock.

The company has its headquarters in the capital city of Riyadh, It employs close to 1,000 employees divided into three areas: ennstruction and commercial works, administration, and planning and development. Projects and activities of the company since ic started operations in 1977 include: (Saudi Real Estate Co., 1982)

1. Importing of building materials and marketing these within the local markets based on cost and not on demand. Materials include steel, lumber, and other building materials. The company has also constructed warehouses totaling almost 10,000 square meters for its operations.

2. Construction projects within the city of Riyadh:

a A1 Sitteen Project: 103 residential apartment units;

b. Al Solaimaniah Project: 136 residential apartment units;

c. Al Morabaa Project: 78 residential apartment units; and

d. AJ Olaya Project:* Included 330 detached single family villas, 1000 residential units (apartments).

*0nly 255 villas in this project have been completed. Apartments in the process of construction number about 675 units. 
The later project (Al Olaya) was a Planned Unit Development type project with a hotel and offices, included in the overall design. Projects in items (a) through (c) above were similarly planned to include office and/or retail space along with the residential units. Residential units were generally of good or better quality and aimed at the moderate or higher income earners.

3. The compay has achieved a profitable operation level. In 1980 net profits before "zakat" (taxes) and miscellaneous distributions were almost 40 million riyals. In 1981, the figure rose to almost 75 million riyals.

It should be noted that outside of the city of Riyadh, only one project--a "commercial complex" building in Dammam--was completed.

The Saudi Real Estate Co. illustrates the fact that large scale housing projects may be constructed profitably. However, this company's efforts in residential construction have been, thus far, limited to the city of Riyadh.

Building Materials Aids

Government policy regarding building materials has occurred on two fronts. On the one hand, assistance to imports of building materials has been substantial in terms of favorable import duties and the tremendous port expansions discussed earlier, i.e. where ports were able to 
increase productivity to accommodate the increases in demand for building materials, among other imported items. Regarding indigenous production of building materials, government assistance has been provided mainly through the Saudi Industrial Development Fund (SIDF), which was a government body responsible to the Ministry of Finance and National Economy, and was designed to promote development of private industry. Its primary activities have been the provision of interest free loans for up to fifty percent of capital needs and for as long as ten years. It also provided technical and administrative advisory services for its borrowers. A one percent to three percent loan fee is charged to cover administrative expenses.

The fund was established in 1974 by Royal Decree and since then up to 1980, almost 54 percent of its loans have been to inance building material manufacturing projects.

Building materials activities supported by the fund are summarized in Table XIX. Several items regarding the table need clarification.

(1) The composition of building material projects over the years has reflected the changing technology. Increasing sectoral sophistication has been reflected in projects involving precast concrete, prefabricated buildings, and steel construction products. 
(2) The "Number" columns in the table reflect new projects only whereas the "value" columns reflect new projects and expansions.

(3) There existed a backlog in 1980 involying some nine applications in building materials (excluding cement and wood) and 997 million riyals. There were no backlogs for cement projects.

Labor Aids

One of the most important actions by which construction labor bottlenecks were removed was through the substitution of block visas in place of individual visa applications for foreign construction workers. Until the early 1970s the official procedures involved in obtaining a visa and a work permit were very difficult. The block visa quota was established to reduce the administrative burden on Ministry officials and to allow more foreign workers to enter the country. This applied to foreign workers in all sectors. Another important issue here is that foreign workers were not taxed.

Regarding the indigenous work force, efforts were made to provide the necessary personnel to all sectors, including residential construction. These efforts manifest themselves in increased enrollment, both at the college/university and vocational levels. There were four universities offering technical disciplines including 
TABLE XIX

SAUDI INDUSTRIAL FUND ACTIVITIES IN BUILDING MATERIALS

\begin{tabular}{|c|c|c|c|c|c|c|c|c|c|c|c|c|}
\hline \multirow[b]{2}{*}{ Category } & \multicolumn{2}{|c|}{$1975 / 76$} & \multicolumn{2}{|c|}{$76 / 77$} & \multicolumn{2}{|c|}{$77 / 78$} & \multicolumn{2}{|c|}{$78 / 79$} & \multicolumn{2}{|c|}{$79 / 80$} & \multicolumn{2}{|c|}{ Total } \\
\hline & No. & Value & No. & Value & No. & Value & No. & Value & No. & Value & No. & Value \\
\hline Cement & 1 & 350 & - & - & 4 & 863 & - & - & - & - & 5 & 12.23 \\
\hline $\begin{array}{l}\text { Wood \& Wood } \\
\text { Products }\end{array}$ & 4 & 12 & 4 & 31 & 3 & 6 & - & 6 & 2 & 8 & 13 & 63 \\
\hline $\begin{array}{l}\text { Other Building } \\
\text { Materials }\end{array}$ & 17 & 174 & 68 & 506 & 51 & 484 & 40 & 404 & 14 & 491 & 190 & 2059 \\
\hline $\begin{array}{l}\text { Percent of } \\
\text { Total Manu- } \\
\text { facturing } \\
\text { Loans }\end{array}$ & 33.8 & 53.1 & 53.7 & 43.0 & 42.6 & 64.9 & 36.0 & 41.5 & 33.3 & 67.9 & 42.1 & 55.1 \\
\hline
\end{tabular}

Source: Ministry of Planning, 1980 
engineering and architecture. Enrollment in these disciplines during 1974-79 was about 17,600 (Ministry of Planning, 1980). This figure actually overstates the human resources available for the residential and non-residential construction sector since the category "engineering" aggregates the broad array of the fields-- chemical, electrical, and mechanical engineering as well as engineering management.

Regarding vocational training, approximately 16,000 employees completed on-the-job training in the private sector during 1975-80. Many of these, however, were nonSaudis. Regarding public sector vocational training, an additional 20 facilities to supplement the existing 26 facilities for training is planned so as to achieve an enrollment of about 72,000 by 1985. (Hinistry of Planning, 1980) These figures also overestimate the available manpower for the construction sector because much of the training will be diversified to include industrial type work.

Rent Control

The rent control policy that was established in the Kingdom was viewed as a temporary measure to be lifted when the "housing crisis" was over and the country's housing projects were complete. A "general basis" agreed upon in the kingdom was expressed as the freedom of contract between landlord and renter. The basic regulations 
regarding controls were as follows (Saudi Regulations, Bulletin, 1979, 1980):

(a) In 1975 the Council of Ministers limited rents increases to five percent above 1973 levels for existing units.

(b) In 1979, for landlords who stayed within the 5 percent allowable increase, an additional 15 percent increase was allowed. For those who owned pre-1974 units and exceeded the alluwable cumulative 20 percent ( 5 percent in 1975 and 15 percent in 1979), adjustments to limit the increase to 20 percent retroactively were to take place.

(c) In 1980, no rent increases were allowed on existing units (except for those mentioned in items (a) and (b) above) until 1983, when all rent controls were to be lifted.

The effect of these regulaticris on the housing market is not readily apparent. Housing starts appeared to be strong throughout the regulation period.

Two issues remain to be discussed. One is the institutional setup of the private sector to deal with housing demand, and the other is provision shelter for the poor.

Institutiona1 Response

The private sector accounts for most of the Kingdom's 
construction activity. In 1973 there were 581 business establishments throughout the Ringdom involved in construction and building and employing 14,679 workers, 52 percent of which were Saudis. By 1976 and in response to the increases in demand for living space, among other goods and services, the number of establishments increased to 1347 employing almost 80,000 workers. (Central Department of Statistics 1981) In 1979, the number of firms was 1812 employing 88,000 workers. (Central Dept. of Statistics, 1981)

Entry into the industry was apparently easy even for small firms. In 1976,80 percent of al1 registered construction establishments had less than 50 employees and only 13 percent had over 100 employees. In 1976 the majority of large scale contractors (about 140 out of 215) doing work volume that exceeded 10 million riyals were foreign. Growth of the construction sector generally ayeraged 19 percent annually during the 1970 s (Ministry of Planning, 1980, p. 255). In 1979/80 the industry contributed about 20 percent of the non oil Gross Domestic Product. Productivity in the sector grew by about three percent per year during the 1970s, according to Ministry of Planning estimates (Ministry of Planning, 1980, p. 256). The increase in responsiveness of the construction sector is illustrated by the fact that construction costs as a whole were not increasing as rapidly as construction 
volume. (See Table XXI.)

TABLE XXI

CONSTRUCTION COST INDEX AND BUILDING PERMITS KINGDOMWIDE

\begin{tabular}{|c|c|c|c|c|}
\hline Year & Index & $\%$ Change & Building Permits & \% Change \\
\hline 1974 & 55.8 & - & 27983 & - \\
\hline 1975 & 69.8 & $25 \%$ & 44650 & $59 \%$ \\
\hline 1976 & 85.4 & $22.3 \%$ & 67346 & $50 \%$ \\
\hline 1977 & 98.1 & $14.9 \%$ & 70970 & $5.4 \%$ \\
\hline 1978 & 102.6 & $4.6 \%$ & 58497 & $-17.6 \%$ \\
\hline 1979 & 104.7 & $2.0 \%$ & 63780 & $9.0 \%$ \\
\hline 1980 & 111.1 & $6.1 \%$ & 83518 & $30.9 \%$ \\
\hline
\end{tabular}

Sources: Ministry of Planning, Internal Document, 1982 Central Department of Statistics, 1979, 1980

\section{Notes:}

1. Building permits include construction, alterations, (renovations), and compound (or camp) walls. They thus inflate housing starts statistics since not all permits were executed.

2. The construction cost index was constructed by a British consulting firm (Metra Consulting Ltd.) for the Ministry of Planning. It is based upon a British index whose coefficients were adjusted for Saudi Arabian technological differences. The index was updated by quarterly surveys in the major cities. It 
is likely to understate the true increases to a certain extent because it relates to actual construction components irrespective of market effects upon tender levels. The index figure for 1975 was 85.6 and was believed to be in error so an adjustment was made by weighting regional indexes by the building permit proportions.

3. The drop in building permits from 1977 to 1978 was likely to be related to the contraction in activities of tine Real Estate Development Fund in its fiscal year 1977/78, where loans granted dropped by over 90 percent.

Entry into the construction sector is probably understated because foreign firms participated in construction, usually with the assistance of or in association with indigenous firms. It was not unusual for many indigenous firms to include foreign firms in the bidding for and later be responsible for the whole construction operation. Additionally, many Saudi Arabian individuals became their own building contractors in times of very high prices. However, the figures for number of contractors is likely to be dampened by the fact that smaller firms may be registered in more than one trade, including residential construction, but that trade may experience 1ittle, if any, activity.

Finally, the issue of institutional readiness (or lack 
thereof) should address the public sector. This sector was experiencing manpower problems as great as, if not greater than those in the private sector. Shortages in manpower throughout the sector were compounded by a wage differential between public and private sector employment. It was not uncommon to encounter a 50 percent or more salary differential for the same type of job. The public sector wage structure underwent several changes throughout the middle and later part of the 1970s, but private sector wages were quicker to respond to changing conditions. The implications of these responsiveness issues shall be dealt with in the next chapter.

Housing for the Poor

Specific policies aimed at housing the poor in Saudi Arabia included the following:

1. The First Low Income Housing Project of 1973 As mentioned earlier in this chapter, this project, comprising almost 3250 units in the major metropolitan areas, was abandoned and no plans as yet have been announced as to its fate.

2. The Serviced Plots Programs (or Land Grants Program)

There were 44,300 serviced plots were to be provided to poor household Kingdomwide so that they can construct their own housing utilizing the Real Estate Development Fund Loan. This program was to lie 
within the domain of the Ministry of Municipal and Rural Affairs and the respective municipalities. Delays in the program were experienced and Riyadh was the first city to start its serviced plot program. It recently granted several thousand plots at one site (A1 Oraijah) within the city to low income households. It also offered assistance with architectural designs so that poor households could obtain Real Estate Development Loans and proceed with the construction.

In the city of Jeddah, there were delays in completing and delivering the serviced piots to deserving low income households. Ten thousand plots were planned for in the newly developed South Jeddah area, but were incomplete in 1983. The site is a 13.5 square kilometers of desert with lot sizes varying from 400-2500 square meters (Sert-Jackson, 1980). Land grants for low income households generally include the following conditions:* 1. That the applicant owns no other land ci house;

2. That she/he be a permanent resident of the city and a Saudi Arabian national;

3. That she/he build on the land within four years of the grant;

* Source: Jeddah Municipality Land Grant Applications and interviews, 1983 . 
4. That the grantee shall not rent, lease, or sell the lot (built or unbuilt) within five years of the grant;

5. That building will be in accord with an approved building permit from the municipality of Jeddah.

Another means by which low income households could be granted land is through the Crown or the Royal Cabinet grant. Any individual Saudi national could apply for a parcel or plot of land from the government, and many applications were to the King himself. However this State Land Grant system was not specifically targeted at the low income population, and itis not known how many low income households were impacted directly or indirectly, e.g. through filtering.

In 1980, a Royal Decree ordered the termination of agricultural and residential land grants except for those people who have not been granted land before.* This Royal Decree limited the extent of the Grants program.

Housing Through Charitable Institutions/Individuals

In the city of Jeddah, several privately funded "housing for the disadvantaged" projects exist. These housing structures are usually purchased and operated by

* Source: Journal of Saudi Regulations, 1980 (King Abdul Aziz University). 
charitable organizations and/or individuals. They have existed in the Western Province and in Islam for many years and the coming of the oil wealth has contributed to their expansion and renovation. The endowment houses (Roubat)typically house the elderly and the very poor irrespective of nationality. Some have operating subsidies paid by the Ministry of Pilgrims and Endowments to cover items such as utiities and some supplies. Another organization that includes aid for the Arbitah is the Al Faisaliah Women's Charitable Cooperatiye in Jeddah.

This cooperative performs a range of charitable and social functions including supervision of 16 Endowment houses scattered throughout Jeddah, housing about 1120 people including 360 children. Dwelling conditions range from very poor-- needing better electric service, better plumbing, refrigerators, cooling fans or air conditioners, and cookers-to very good, well furnished facilities. The number of residents vary from seven (Roubat A1 Lami) to 64 (Roubat Ali Nasseef) and an exceptional Roubat (Bin Mahfouz) housing about 800 individuals.

The Bin Mahfouz project represents a successful attempt by the private sector to house needy low income households. Bin Mahfouz is a very successful and well

\footnotetext{
* The basis of this charily is sheer altruism and religinus princinle = There are no tax advantages to operating these homes.
} 
respected Saudi businessman who set up the Roubat close to his home. It was constructed in 1979 and consists of three high-rise buildings containing 288 apartment units of moderate quality and with 80 square meters each. These units house, free of charge, about 800 low income individuals, including 400 children, Residents are provided also with a single daily meal (lunch) and given a food in-kind aid every three months. Utilities are also provided free of charge (limited telephone service is included), as is free emergency medical care by a nighttime, resident physician. Only one supervisor is responsibile for three buildings and--based upon a site visit--it appears to be an efficient operation.

The construction costs for the three high-rise buildings were approximately 45 million riyals in 1979. Operating expenses average approximately 80 thousand riyals per month, or roughly one million riyals per year. One of the interesting facts about this project is that it receives little support from the government. Funding is provided by the project's owner, by the Al Faisaliah Charitable Cooperative, and by charitable acts from many individuals.

Another example of a large scale cooperative housing project provided by a non-profit organization, illustrates that construction costs on relatively large housing projects do not necessarily have to be as expensive as the 
public housing projects. The Prince Fawaz Cooperative Housing Project was started in Jeddah in 1974-75 by 150 people from the University of King Abdul Aziz. Land was donated by the Government. The project grew to 1,500 members, but encountered land disputes and administrative difficulties. Additionally, the initial contractors charged with building the project, a Spanish contracting firm, abandoned the projest midstream. The project had to be redesigned and is summarized on page 130 . The project utilizes precast construction techniques and is of very good-to-superior quality. The project is expected to be complete by the end of 1984 (100 units were already complete in 1983, but infrastructure and utilities were incomplete). Finally, an application to purchase involves a fee to become a co-op member, which is applied towards the home $(10,000$ riyals $)$ and there is a group plan by which all owners can automatically receive REDF funding for 300,000 riyals if they are eligible. The following highlights the project:

Total Land Area Design

Number of Units A : ticipated Population
5.73 milion meters PUD including 9 kindergartens

6 elementary schools

2 high schools

6 supermarkets, etc.

Approximately 1500

Approximately 10,000 
Plot size

Unit design

Construction Cost
$900 \mathrm{~m}^{2}$

Semi Detached Villas, 2 stories

Large Villa area, $435 \mathrm{~m}$

Medium Villa area, $408 \mathrm{~m}^{2}$

Small Villa area, $361 \mathrm{~m}$

Approximately 1100 riyals to 2361

Iiyals per $\mathrm{m} *$

Housing Policy for the 1980s

1. Demand

Demand estimates for urban areas within population of 30,000 or more ws estimated to be 450,000 units (Ministry of Planning, 1980, p. 448). This figure includes new household formation, replacement of substandard units, and replacement due to accidental losses. Overall demand (including rural areas) was estimated tobe 730,000 units.

\section{Supply}

Public housing is expected to provide 10,000 units in new projects. These include the 6883 units mentioned in Table VII under the title New Projects. There is also mention of a special housing project to specifically "assist lower income households to find adequate housing" (Ministry of Planning, 1980, p. 449). Indeed, the whole focus of the public housing program appears to be directed towards low income households. To identify exact needs, * Sources: Interviews with Project personnel, and the consulting firm in charge. 


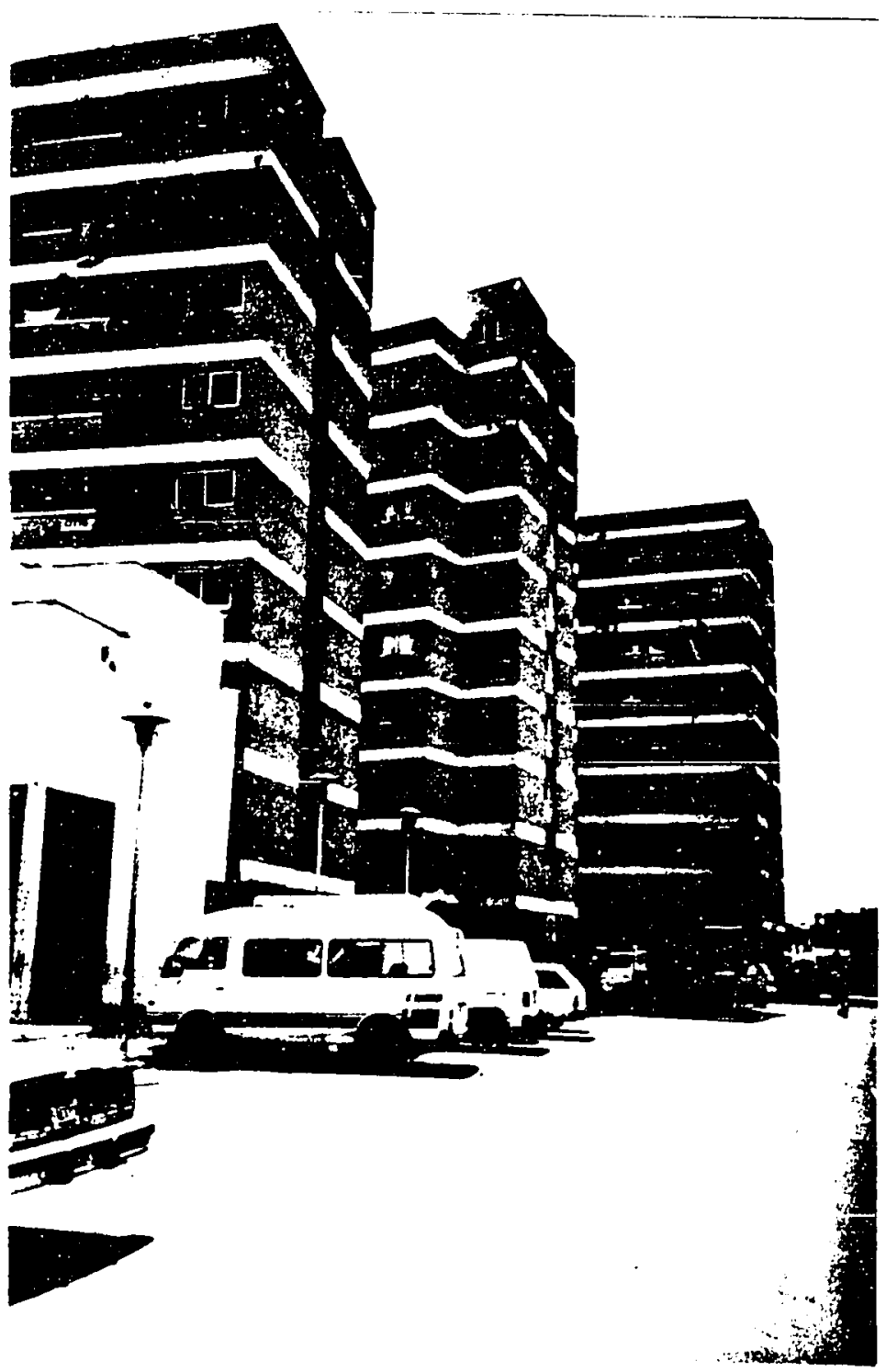

Figure 9. The Bin MahFouz Endowment (Roubat), Jeddah

Note the differences in size, capacity ( 800 versus 11 residents), clientele (families in Bin Mahfouz, women only in Al Khounji), quality of construction and location (AI Khounji is in the Central Business District whereas Bin Mahfouz is in a less congested section of town). 


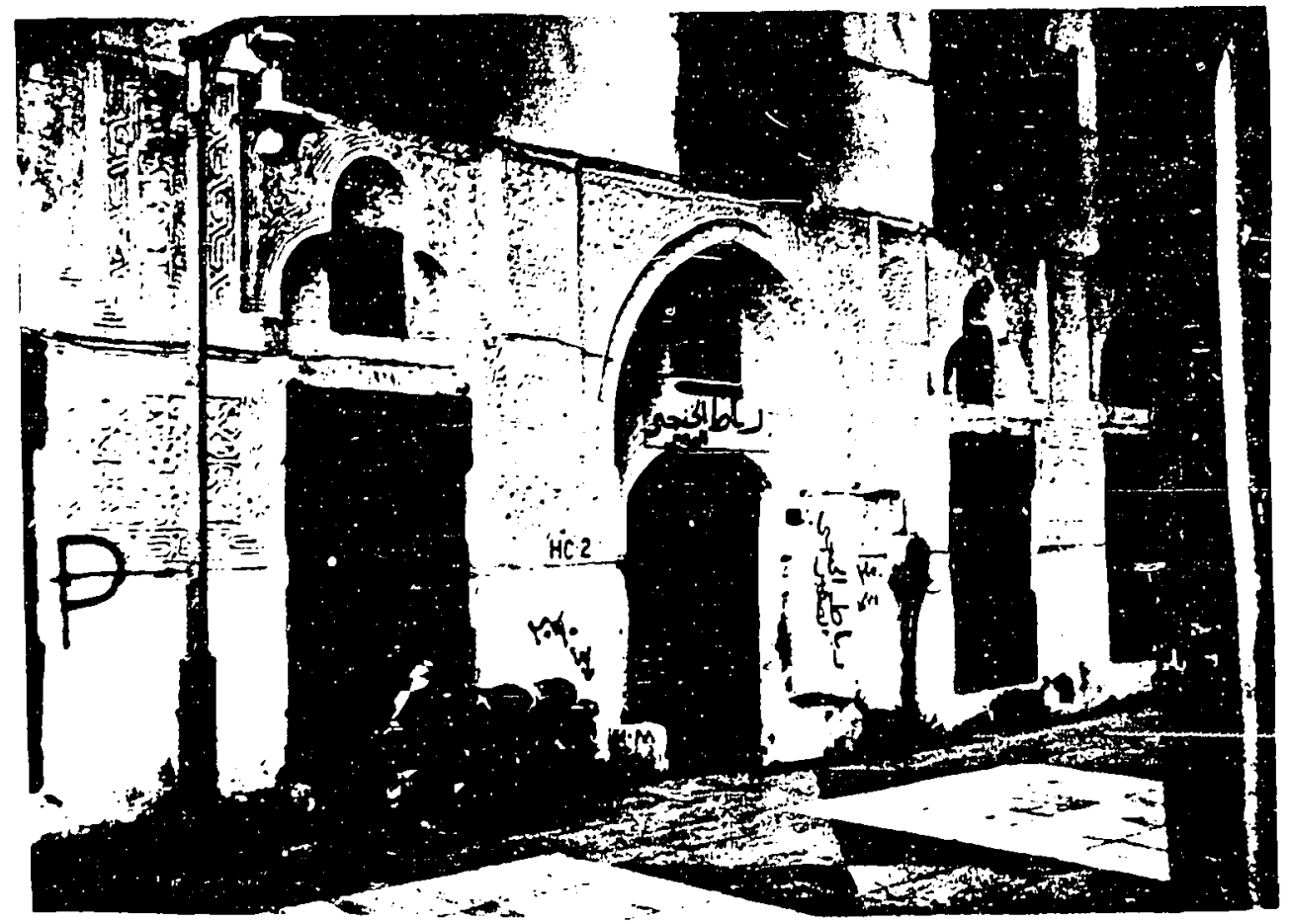

Figure 10. The AI Khounji Al Sagheer Endowment (Roubat), Jeddah

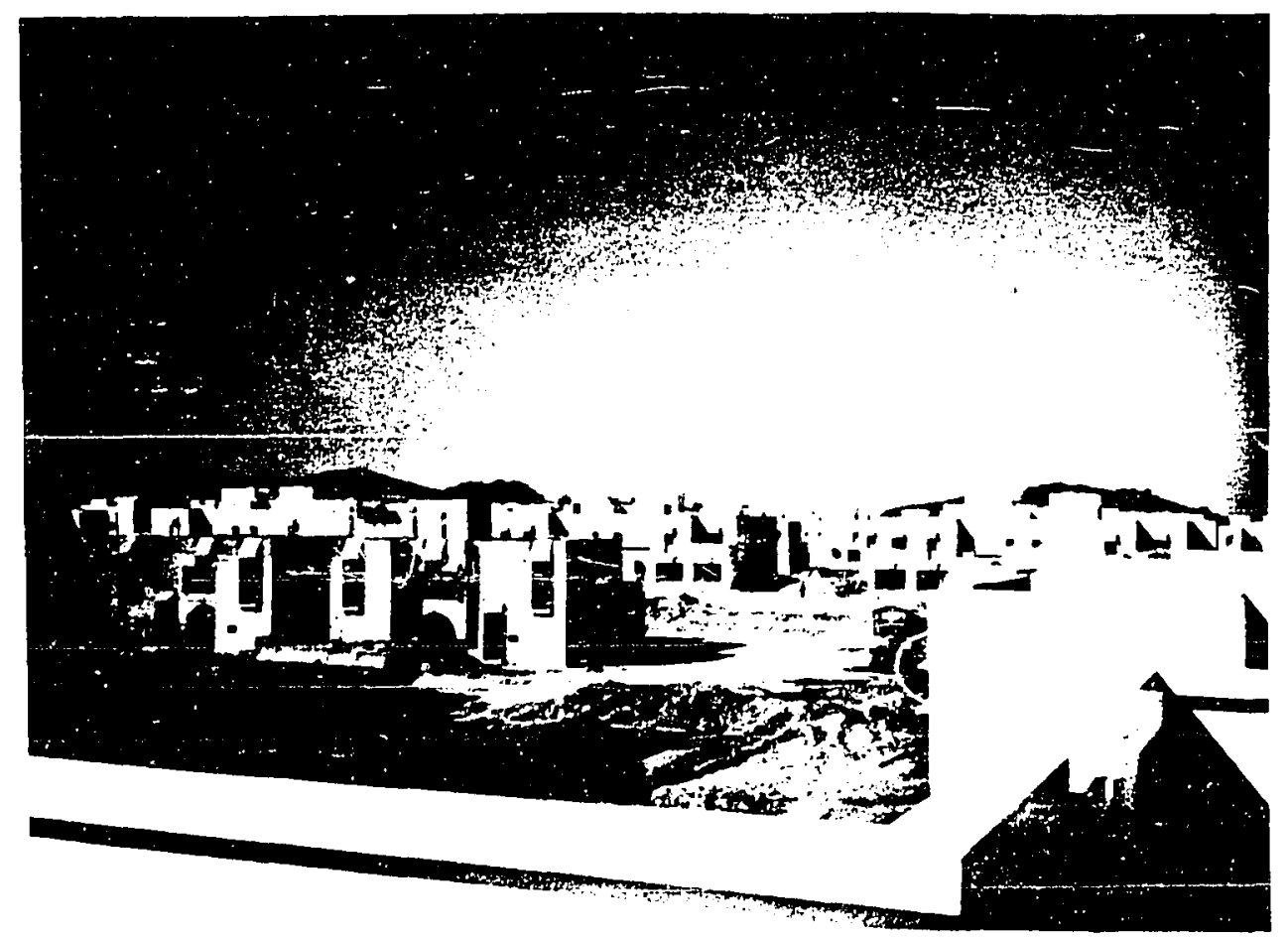

Figure 11. Prince Fawaz Cooperative Housing Project 
TABLE XXI

PLANNED HOUSING SUPPLY ESTIMATES $1980-85$

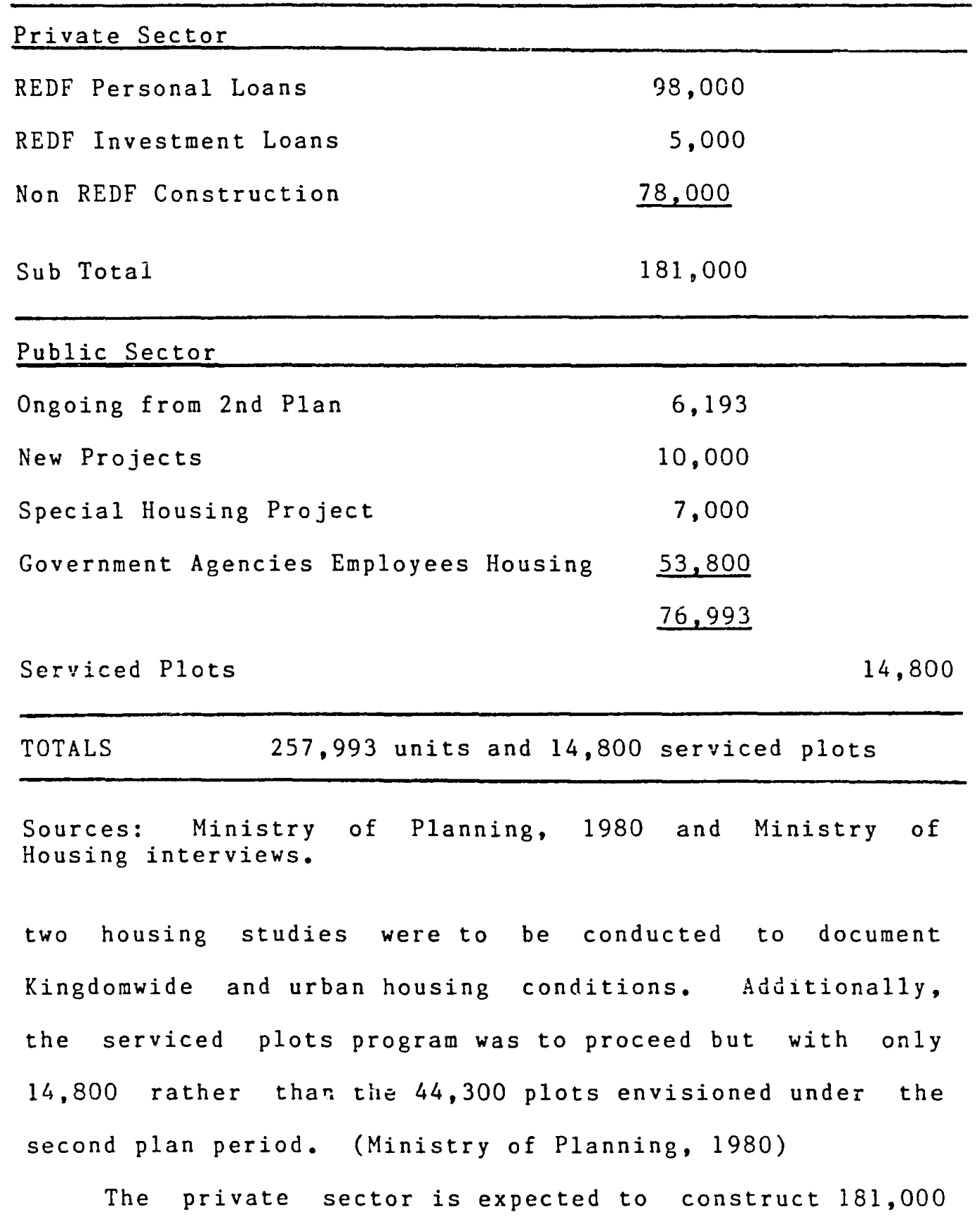


units in the period 1980-85. Of this figure, 54 percent are expected to be constructed through REDF loans. A total of 13,816 million and 805 million riyals will be available for personal and investment loans respectively, subject to market requirements. Total quantitative needs and supply are 1 isted in Table XXI.

Several issues regarding the above should be noted:

1. Under public sector programs, the first item, "Ongoing projects," represents the 1152 Rush Housing units in Riyadh which were already completed in 1982 and the 5041 units in Rigadh started in 1978 (See Table XVI).

2. The new public housing programs include the 6883 units mentioned under new projects, also in Table XVIII.

3. Information is limited regarding the "Special Housing Project," except that it is to be a low income housing project dispersed over several smaller urban areas within the Kingdom.

4. The Government Agencies Employee Housing involves various ministries and agencies and specific jrformation about the projects were unavailable. As mentioned before, this figure represents public sector housing (for government employees) which should not be confused with publis housing (for lay citizens).

Summary and Discussion

The housing policy achievements compared to the 
Kingdom's expressed housing goal and objectives may be summarized in the following:

1. Regarding the broad housing goal of attaining a decent home for every household in the Kingdom, achievements fell short. The socioeconomic survey mentioned earlier for the city of Jeddah indicated a 40 percent home ownership rate among Saudi Arabian families. Additionally, almost half of all the buildings in Jeddah were in fair condition (requiring some form of repair) or worse.

A caveat regarding the above is in order. Most data are from a survey conducted in 1978, only three years after the beginning of the Second Development Plan. It is likely that an improvement in the home cunership rate as weli as building conditions could have occured due to rising incomes and reductions in housing costs since that time.

2. The quantitative objectives set for the private sector achievements (122.1 thousand units) were actually exceeded; 150 thousand units were completed from 1975 to 1980 , a 123 percent achievement rate.

Private sector assistance through the REDF and other measures, as mentioned, were provided by the government.

3. Project housing achieved a 100 percent achievement rate ( 51,000 units). 
4. The public sector low income serviced plots program, scheduled to provide 44,300 plots, had a zero achievement in the five year period 1975-80. However, in the early $1980^{\prime}$ 's several thousand serviced plots were said to have been distributed in Riyadh. Interviews in 1983 indicated that distribution of 10,300 serviced plots in Jeddah was "nearing completion."

5. Information on public housing projects was not readily available. However, as indicated in Table XVI, 12,338 units were completed by 1983. There were 5,041 units in the process of construction in the city of Riyadh. Even if these latter projects are completed soon and counted as achievements, the sad fact remains that all units were vacant as late as March 1983. Additionally, even if the units were not vacant, the cost was substantially higher than private sector dwelling units, for example, the Jeddah General Housing Project, which was recently completed, utilized local building resources and a longer time frame than the costlier Rush Housing Project. It cost about 1700 million riyals for 3,420 units, or approximately one half million riyals per unit. The space per unit is approximately 220 square meters which brings the cost per square meter to roughly 2273 riyals/square meter. This cost element does not 
compare favorably with per meter construction costs in the city of Jeddah, which range from 1100 riyals/square meter for "economy" units to roughly 2200 riyals/square meter for "standard" quality to 3000 riyals/square meter for "very good or luxury quality villas.* The units in the public housing project would likely fall in the category of economyto-standard.

The Prince Fawaz Cooperative Housing Project in Jeddah is perhaps more accurate to use as a basis for cost comparison by virtue of its size. This project was mentioned earlier in this chapter. Its cost per square meter, despite a definite superior quality, ranges between 1100 to 1361 riyals per square meter.*

6. The list of accomplishments for public housing included 53,600 units completed in the period 1975-80. (Ministry of Planning, 1980) This implied an achievement rate of 102 percent, i.e. Public Housing quantitative goals were 52,500 as identified earlier in Table XVI. However, there appears to be a terminology problem here because public housing programs-as used in this dissertation--do not include government agency employee housing and military housing. Official figures apparently aggregate public housing along with public sector housing.

* Based upon interviews with project personnel. 
7. Institutional set ups to support housing development as envisioned in the statement of housing policy objectives e.g. financial and legal services, have not been effectively developed as yet. It is not clear who has the authority for defining, constructing, and implementing these institutional structures, i.e. whether those structures would be within the domain of the Ministry of Housing, the Ministry of Planning, or the local governments (basically the municipalities).

8. Housing assistance from the public sector specifically directed at the poor was relatively weak. Private sector contributions, however, were relatively substantial.

9. Apparently, no studies were conducted to identify low income households--their numbers, locations, and housing needs. A need for these studies was mentioned in the Second Five Year Plan. (Ministry of Planning, 1980, p. 449)

One of the most important findings is the large effectiveness gap that exists between public and private housing construction. The private sector, with government support, has shown a capability to respond to conditions of rising demand with a considerable degree of effectiveness as reflected by the number of housing units constructed over the documented period (1975-80). Public housing projects have been, as the record indicates, historically 
troubled. Billions of riyals have been spent on miscelianeous projects which have to this date (1984) been unoccupied. Furthermore, the low income land grant program has not been successful. These results do not necessarily reflect on the intentions and/or the capability of Ministry of Housing personnel. Institutional elements probably have the greatest effects, as well as manpower shortages.

One of the most important outcomes of the poor performance of public housing is that the scctor of society that bears the greatest burden is the less advantaged one, i.e. low income households. These householdswere to be the beneficiaries of public housing, and are deprived the most due to the delays and/or indecisiveness about"who will live where" problems of public housing. Society as a whole may be worse off considering the increases in building cost in the public housing projects over and above similarly constructed private sector housing. These increases represent wasted societal resources unless enough quality differences exist to warrant the additional cost, and upon-. site visits, public housing projects were found to be of high quality. Comparisons with private sector housing is difficult due to a general lack of building codes and recent data on housing conditions.

In summary, the greatest potential for improvement is identified in those policy components that involve direct involvement in the housing sector by the public sector, 
namely public housing and the land grant program. Other programs achieved a greater degree of success. 
CHAPTER V

HOUSING POLICY EVALUATION

Introduction

Two bases of evaluation are presented in this chapter. The first involves the individual policy outcomes based upon the Kingdom's own housing goal and objectives. The second basis draws upon the theoretical framework developed in Chapter II, which dealt with rationales of housing policies.

An evaluation of housing strategies is also presented; including supply and demand support strategies. Finally, institutional structure will be discussed.

\section{Evaluation Based On Objectives}

In the previous chapter, outcomes of the various components of the Saudi Arabian housing policy were discussed. These outcomes are summarized along with the objectives for each policy component in Table XXII.

Based on the stated objectives, the most effective policy component was private sector housing construction. The private sector was aided by the government in areas such as building material subsidies, labor assistance measures, and home financing subsidies. Achievements were 
TABLE XXII HOUSING POI.ICY OBJECTIVES AND ACHIEVEMENTS

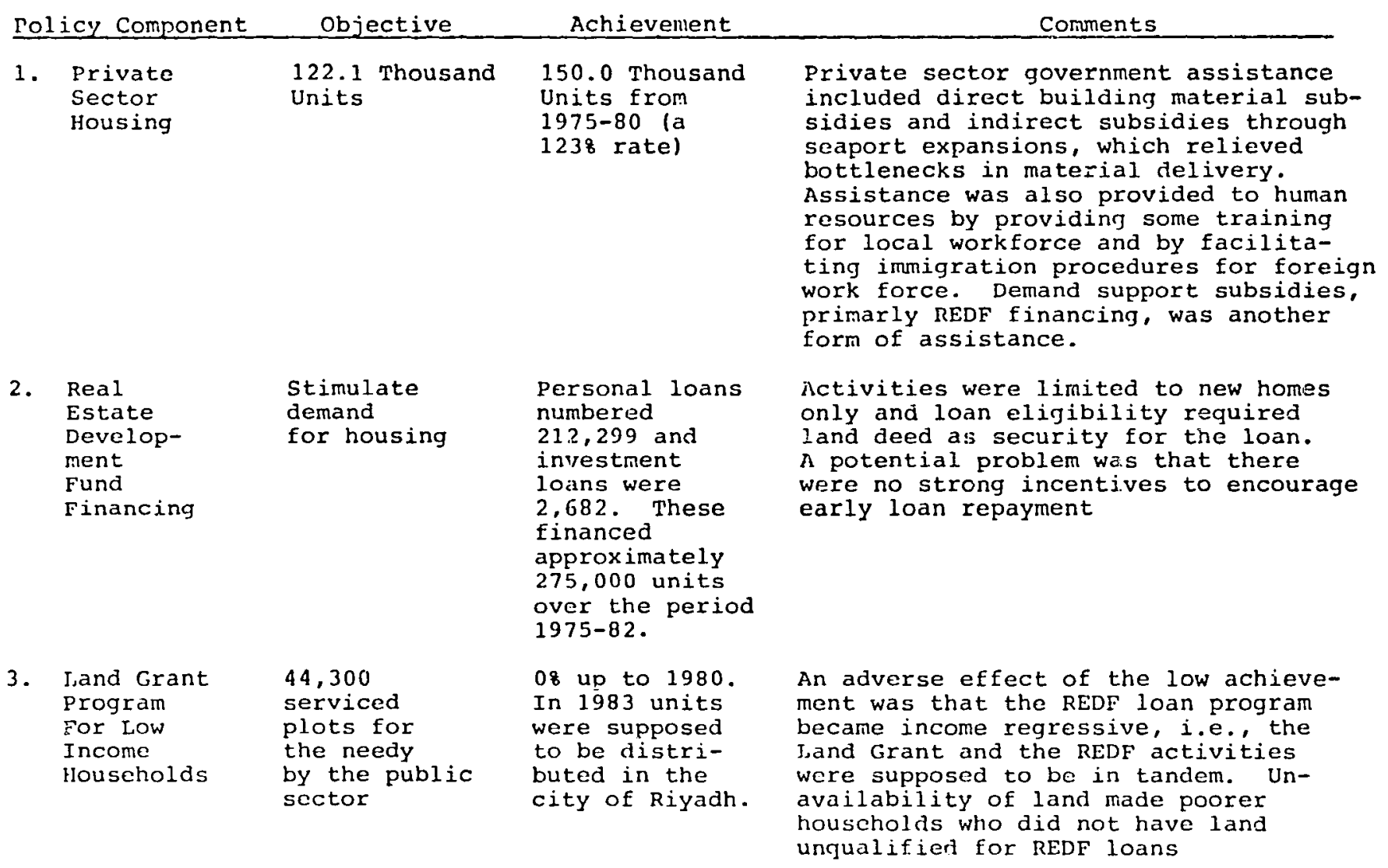


TABLE XXII (Continued)

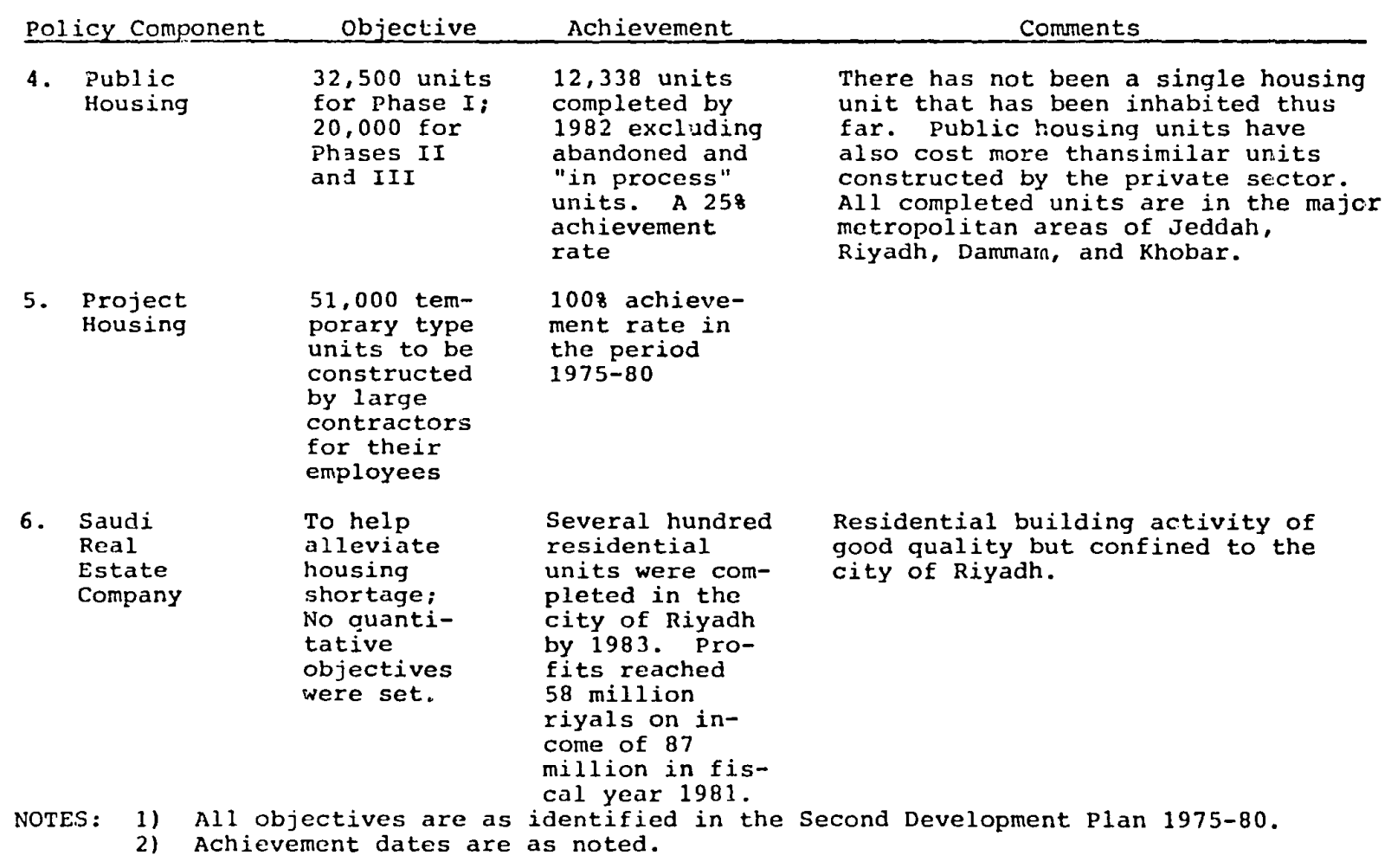


impressive. In terms of numbers, a 123 percent rate of the objective was achieved during 1975-80. Since 1977 Housing costs, have stabilized and declined (see Table V). The costs of housing are actually not well represented by the index, because quality is not taken into consideration. If new units are of better quality than old units, the cost index will overstate true cost increases. Data on the quality of housing units was not available for the whole Kingdom. However, based on information available for the city of Jeddah, it is safe to assume that new housing is of better quality than old housing in attributes such as structure, internal space, ventilation, and access. The implication of the above is that a portion of the cost difference between new housing and old housing is likely to be due to quality differences.

The issue of private sector responsiveness to housing demand cannot be fully analyzed because there has not been an investigation of the supply elasticity of housing. However, certain elements indicate that a responsive private sector is not an unreasonable expection. These include the rate of entry of firms into the construction sector, the extent of government assistance in providing building resources to the housing sector, and the lack of

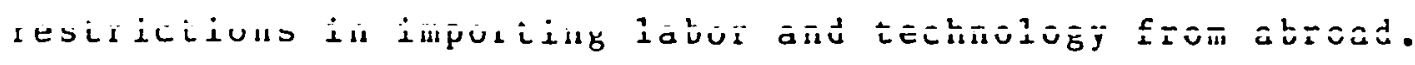
Direct public sector involvement in housing through public bousing and the land grant program were the least 
successful components of housing policy in terms of meeting housing objectives. As mentioned earlier, problems of higher costs and delivery reduced the effectiveness of public housing efforst. Several implications of these problems need delineation.

The effectiveness gap between the public and private sector implies that resource utilization could have been improved had the private sector been more involved in public sector projects. As an example of this reasoning, the Rush Housing Project was, as mentioned earlier, built to relieve the housing shortage in the Kingdom during the mid 1970s. The project was to house middle-income and lowincome households in the shortest time possible and with the least disruption to the already bottlenecked resource markets. Farahat and Cebeci (1982) evaluated the project and found that it could have utilized a design and development strategy that would have been more effective in terms of integration into the community, better design acceptance, and in construction management if local firms had been involved. Specifically, they compared an incremental phased development--approach to the "large lump" approach, with low-rise -..ner than high rise units, and a scattered rather than a concentrated approach. As a result, an actual savings in time--from making the design decision to occupancy--would have resulted while not affecting the number of units. 
This analysis addressed design and efficiency issues. It did not address the fact that land for the "Rush" project was scarce and that the project required preserviced land with all utilities included. Furthermore, the Ministry of housing did not view the local corstruction firms as being sophisticated enough to handle such a large project, especially since earlier experience with the low income public housing project of 1973 set an unfavorable precedent. However, those characteristics by themselves do not justify the cost differentials and the fact that the units are vacant. The vacancies can be attributable to institutional problems in that no institutional structure for distributing and administering public housing exists, such as a public housing authority. Additionally, the establishment of criteria for identifying deserving clientele for public housing has not been done.

Clientele selection is a problem that exists for this and other public housing projects. Even if consensus is reached that the unils be given to low income households, there is a problem in identifying who are the appropriate qualified groups.

Another potential problem is that of equity. Solomon (1974) identified the concept of vertical equity as the extent to which households of unequal status are treated equally. Horizontal equity was identifed as the extent to which households of equal status are treated equally. Even 
if low income households are identified and given units in public housing projects, they would end up in higher standard housing than some of the lower middle, income households, and the project would be vertically inequitable. Additionally, if the housing projects do not house all the poor households who are in equivalent levels of poverty, it would be horizontally inequitable.*

In addition to public housing, the other direct public sector involvement in housing was the land grant program which was to provide serviced plots--with all utilities provided-for low income households. This program encountered conceptual and outcome problems. The idea of having large tracts of land subdivided specifically for low income plots has the potential of segregating a given city by income and social class, and poses the threat of establishing low income enclaves. Information regarding the existing degree of income or other segregation within the cities in the Kingdom was not available. However, if the assumption is made that housing pkolicy should aim at reducing segregation, the criticism becomes a valid one. In terms of outcome, delays in the land grant program not only prevented low income households from obtaining land, but it also made the activities of the Real Estate Development Fund (REDF) regressive. The very poor, who

*Horizontal equity was also referred to earlier as the "Lottery" feature in Chapter II, under "Public Housing." 
could not afford to buy land, could not obtain the subsidized home loans because of the requirement of having title to the lanc. However, some of the poor households received benefits from other social programs, including the Crown Grant Program.

The Saudi Arabian Real Estate Company was successful in building housing units, as illustrated by their quantitative and financial achievements. That success was limited geographically to the city of Riyadh.

The final housing component to be dealt with is the financing activities of the Real Estate Development Fund. As mentioned before, this organization was the only one that provided long-term home financing in the Kingdom. The absence of mortgage financing was due to the laws forbidding usury and the charging of interest, as well as the relative unsophistication in the lending activities performed by banks and other financial intermediaries. Additionally, a regulation which prohibited banks from holding real estate as an asset affected the loan situation. Finally, difficulties in assessing homes and real estate in general made real estate financing even less likely.

The REDF appears to have been effective in inducing housing starts. According to REDF data, over 90 percent of the housing units built in the period $1975-8$ were REDF 
financed homes.* This need not imply that all the units built were due to the loans. Some would probably have been built anyway. The 1oans, however, were granted for new homes only, and therefore investment in existing homes was not stimulated. Those had to be purchased either by outright cash or by using short-term ( $1-5$ year) loans which could not be turned over, as is the case for some types of variable rate mortgages. A potential problem area for continuing REDF activity is capital availability. Capital was to be provided by outstanding loan repayments and government allocations. Personal loans were granted for personal housing--as opposed to investment loans, which included rental housing as well as commercial and office space.

The personal loans had a 25-year term with a two-year grace period, a zero interest rate, and a 20 percent discount for on-time payments and a 10 percent discount on early principal payment. Investment loans had identical conditions, but that they involved a ten-year term. Loans were not transferable upon home sales. These conditions imply that the annual capital available for the REDF is dependent on:

$$
\begin{aligned}
& \text { Outstanding personal loans } \\
& \text { - Outstanding investment loans }
\end{aligned}
$$

\footnotetext{
* Sources: REDF Seven-Year Report and Third Development Plan (1980).
} 
- Early repayment due to financed home sales

- Early repayment due to "altruism"

- Government allocations

"Altruism" refers to repayment incentives that are contrary to rational economic judgement and involvo feelings of well-being toward expanding the loan base for other potential borrowers.

The preceding statement implies that more and more government funds will be required to sustain the growth rate of loan disbursements by the Real Estate Development Fund unless incentives are provided to accelerate early repayments. Thus far, ten percent of the outstanding loan balances have been repaid.

A case can be made at this point for instituting a financing arrangement for existing homes. This would represent an incentive to encourage investment in the existing housing stock as a demand support policy directed at existing homes. It would also help to expand the REDF loanable capital if the loans for existing homes are not as generous as they are for new homes, i.e. stimulating sales of existing homes would stimulate early repayment due to financed home sales, which is a determinant of capital availability for the REDF. If the loans are based on the same terms as those for new homes, the effect will be a shifting of loanable funds from new to existing homes. 


\section{Evaluation Based On Theoretical Framework}

In developing a general theoretical framework for government support of housing in Chapter II, equity and efficiency rationales dominanted other bases of housing policy. This section will utilize primarily these two bases for the evaluation of priorities. However, other rationales will also be discussed.

\section{$\underline{\text { Equity }}$}

In terms of equity, which refers here to a "fair distribution of adequate housing," housing policy in the Kingdom has not been very successful. The least privileged households were the ones that received the least benefits. The failure of public housing to provide units for the lowincome households and the delay in the land grant program skewed the benefits of the policy toward middle and upper income households. As discussed earlier, in Chapter III, a normative basis in Islam stresses "equitable" income and wealth distribution. Even though no specific criteria exist to define "equitable," it is apparent that the poor and disadvantaged should receive a larger share of the growing wealth in the housing sector than has been the case. The general notion of housing equity applies both in the provision of "minimally acceptable" shelter to the needy groups and also in response to the normative, 
traditional basis of equity identified in an Islamic context.

\section{Efficiency}

In addressing the efficiency rationale identified earlier, two issues arise. The first is that of building sector efficiency and the second, capital market efficiency. An evaluation of the Saudi policy in terms of the former, concludes that government assistance to the private sector through building material subsidies, through labor assistance measures, and financing measures did in fact achieve effective results as reflected by its achievement rate. Other measures of achievement include the decline in construction costs and housing costs.

The issue of capital market efficiency is difficult to address. Capital markets, or markets dealing in the supply and demand of long-term loanable funds, did not and still do not exist. The reasons were discussed earlier are due to the lack of sophistication of the financial systeri, partly due to the prohibition of interest charges in conformance with Islamic principles, and banking regulations. The activities of the Real Estate Development Fund represents a quantum leap forward in terms of house financing in the Kingdom. Over ninety percent of the homes built in the 1975-80 period were financed by the REDF, according to official figures. This, however, need not imply that 90 percent of the homes were built due to the 
REDF. There is still potential for improvement by expanding the financing scope for home loans to include existing housing.

Spatia1 Aspects

The stated objectives of the Saudi housing policy were to concentrate housing where demand was greatest. Housing was not used as part of a regional growth center strategy instrument.

As far as intraurban spatial aspects are concerned, public housing and serviced land grant location policies encouraged segregation. The segregation by income and/or region that was likely to result can have many unfavorable effects, including dissatisfaction, feelings of alienation, and overall area stagnation.

\section{Macroeconomic Effects}

The first low-income public housing project in 1973 depend on local contractors. It was said to have suffered from quality problems which justified use of foreign contractors for the much larger projects that were built later (SCET, 1975). The 4,812 unit Rush Housing Project in the three metropolitan areas of Jeddah, Riyadh, and Dammam was designed to be built in a very short time span and did not use local contractors or building materials, so as not to disrupt the already constrained local markets. The 12,567 unit General Housing Project was started when 
constraints on the building sector were viewed as being less severe. Local building materials were utilized, but the magnitude of the projects compared to the available local resources necessitated utilizing foreign contractors, consultants, and workers on a "turnkey" project basis. As a result, macroeconomic stimulation cannot be claimed as a significant result of these public housing projects. Private housing starts share a similar record as far as employment effects were concerned, i.e., employment benefits were likely to be small due to the inability of local manpower to execute the construction requirements. As an induced effect of government stimulation of private housing, increased incomes for local building contractors and landlords resulted. This, however, is an income distribution issue.

Public housing projects appear to have had very weak macroeconomic effects in terms of employment and possibly moderate effects in terms of income generated. Private housing efforts, which were aided by the government, were likely to have fared better in terms of income generated, especially given the dominance of real estate in personal investment portfolios: Employment effects due to private housing were not likely to be significant due to the conditions of full employment existing in the Kingdom.

\section{Internal and External Effects}

As the literature review indicated, the empirical 
evidence reviewed was inconclusive as to the effect and magnitude of improved housing on mental and physical health. However, the literature, for the most part, addressed United States cases. The value of this rationale for other countries, especially less developed ones, was doubtful given the mediating effect of cultural variables in influencing outcomes of housing improvement. Another complicating factor was that no agreed upon levels of "substandardness" were established to judge likely outcomes according to minimal standards.

In Saudi Arabia, three positive internal benefits of housing improvement were viewed as likely. The first is mental and physical benefits due to environmental factors, including the availability of air coolers, which would moderate che difficulties associated with the very warm climate. This effect is not necessarily restricted to new housing, but incorporates a broader issue of housing improvements. A second likely effect is psychological and involves the expectations of increases in standards of living, given the increase in income and wealth that the country has experienced. The third effect may be viewed as the creation of options to change from extended to nuclear families if a given household desires the change. An implicit assumption here is that a housing improvement will include provisions to accommodate this change. This effect may be viewed as a "mixed" effect. It is positive because 
of the potential for comfort that it provides, but it may be negative in that it destroys some cultural elements in the Saudi society.

Given the complexity of the interaction of "satisfaction" and "adaptation" variables, internal benefits will be difficult to delineate within the scope of this dissertation.

The argument also holds for the external benefits of housing improvements in the Kingdom. Development Plans called for growth in all sectors of the economy, such as education, health, transportation, etc. It would be difficult to disentangle the spillover of housing onto the other sectors.

Blockbusting and abandonment practices have not been reported as yet, but this may be an indication of timing rather than absence, i.e., in some areas in Jeddah, several neighborhoods (A1 Sabeel and $A 1$ Ruwais) have experienced declining conditions and rentals due to the changing clientele inhabiting the area.* The new residents are mostly foreign workers. It is not clear as yet whether blockbusting practices are involved. No abandonment problems have been observed in the city of Jeddah.

A final, but important issue related to external benefits of housing is the visibility factor and its

*Based on interviews with Jeddah Municipality
personnel.


political effect, i.e., the visibility of successful housing projects is likely to improve the image of a given political system. In the major cities of Jeddah, Riyadh, and Dammam, the visibility factor was actually a disbenefit. The Rush Housing Project Towers, standing complete and vacant within the city proper, have contributed negatively to the image of public housing policy

\section{Strategies Evaluation}

The earlier efforts by the government in realizing housing objectives were primarily supply support oriented. The immediate aim was to eliminate resource bottlenecks and help the private sector achieve greater production. The strategy was viewed as necessary by the government because the housing objectives greatly exceeded what the indigenous resources could provide. The strategy could be divided into indirect and direct supply support. The former was manifested in miscellaneous resource subsidies for the private sector. It appears to have been successful in inducing supply responses from the private sector. The strategy may also be partly responsible for reducing construction costs through the subsidies and the general support for the private sector provided by the government.

Direct supply support, in the form of public housing, has not been successful in achieving the objectives in terms of the number of units built, their costs and their 
delivery to eligible households. Resources were not efficiently utilized in direct supply support. The Rush Housing Project commanded a substantial cost premium because of the speed by which it was built, but all units have been vacant for many years after their completion, thus defeating a central purpose of the project. Additionally, according to an analysis of the project conducted earlier, the design could have been drawn and planned in such a way as to allow for the utilization of more local resources and yet maintain the project's construction speed. The conclusion from the above is that resources have been inefficiently utilized in executing the Rush Housing Project.

The General Housing Project does have cost drawbacks-although not as severe as the Rush Housing Project. It is more expensive than comparable private sector housing. Also it appears to have problems in delivery. Thus far, no clientele has been selected for this project. Public housing in general appears to have been unsuccessful on the two bases discussed earlier. If public housing is viewed as a means to house the poor because of market imperfections, it has not achieved that objective. Indeed, there are doubts that añy jutic housing can effactively house the poor because of the inherent lottery or horizontal inequity feature, i.e., the housing benefits are usually provided to a limited proportion of the eligible 
households. If public housing is viewed as a means to more effectively utilize resources for building, then here again it cannot be evaluated as being successful. Resource utilization has been apparently more effective in the private sector, especially when assisted by the government through subsidies.

Demand support strategies, primarily REDF activities, have been successful in stimulating housing starts, but there is a great need for expanding the scope of lending beyond new housing. This expansion would have several benefits including the preservation and upgrading of the existing housing stock, promoting the capability of households to buy homes, and, a possible increased repayment rate for REDF funds. The timing of increased financing efforts is also of importance. The financial system in the Kingdom should have attained a higher level of sophistication and it is also accessible to more urban and rural areas. The financial system should be viewed as a resource to affect a wider range of housing programs. Constraints, however, do exist and are serious enough to warrant public sector efforts. Specifically, there exists no capital market and the charging of interest is frowned upon by religious authorities.

Two possibilities exist to achieve a wider scope of financing. The first involves utilizing the already specialized operation of the Real Estate Development Fund. 
The second involves encouraging the existing banks, including the Islamic banks, to participate in the mortgage lending activity. Encouragement by the government would include an insurance scheme for long-term loans such as the FHA progam which started in the 1930s in the United States. It would also include minimizing regulatory effects which prohibit banks from long-term lending in real estate.

The issue of interest on loans, which is not allowed within an Islamic context, is beyond the scope of this study, however possibilities do exist as illustrated by Islamic banks' interest free operations. Additionally, the new mortgage instruments beyond the simple fixed-rate long term self amortizing loan can be evaluated for applicability to the normative setting.

Institutional Structure

Another issue to be evaluated is the housing institutional structure. The first low-income housing project of 1973 was initiated when the Ministry of Housing was the General Housing Department under the Ministry of Finance and National Economy. In interviews condlicted to determine why the project was unfinished, it was mentioned that the project was not the responsibility of the Ministry of llousing, but "belonged" to the Ministry of Finance. The latter Ministry in turn claimed that responsibility for the project was with the Ministry of Housing. In trying to 
determine why the existing public housing projects are vacant, it was suggested that the Ministry of Housing is the implementing body. It does not set policy, but orly implements objectives. Responsibility for identification of public housing clientele and for delivery of the housing units was not made clear. Specialized committees for public housing were to deal with these issues, but these committees were not within the Ministry of Housing. Up to the time of conclusion of the research for this dissertation in 1983, formation of a public housing committee was ongoing. The vacancies in the public housing housing units could be explained as being due to two main reasons. First, no criteria for identification of the public housing clientele was available. Second, responsibility for the identification of the clientele and the delivery of the units is unclear.

Finally, a distinction has to be made regarding the housing policy environment. The earlier housing policy efforts were short term oriented, designed to overcome specific housing problems which were resource constraints and the lack of living space to accomodate migrants. In the long run, as more resource bottlenecks are relieved and supply becomes relatively uninhibited, new policy directions may need to be taken. Specifically, policies to promote affordability of homes will be needed. Housing 
policy in the long run would have to take into consideration the impact of reductions in the numbers of foreign workers and the resulting vacancies that are likely to result. Failure to do so will not only result in a potentially drastic contraction of the real estate market, but also threatens to affect other sectors directly and indirectly, such as building, contractiig, furniture, appliances, etc. Even in the absence of cyclical downturns in the economy, an awareness that overinvestment in huusing can result in the housing sector versus other sectors if subsidy programs are not evaluated.

\section{Conclusions}

Private sector activities in housing, when assisted by the government in the provision of resources, were very effective in achieving stated housing policy objectives.

Public housing was generally ineffective in achieving the predefined housing objectives, and was also ineffective as judged bj the theoretical framework which emphasizes equity and efficiency.

Regarding strategies of housing support, it was found that indirect supply support by the government through resource subsidies was successful in stimulating housing construction. Direct supply support through public housing projects have not been successful when judged by the Kingdom's own housing objectives and when evaluated within the equity and efficiency rationales. 
Demand support strategies: primarily the Real Estate Development Fund (REDF) finsucing activities, were successful in achieving a very significant proportion of privately constructed homes. Another demand support strategy was the land grant program. This program was not successful due to delays and potential segregation problems.

Finally, the issue of housing the poor was not very effectively handled. The status of public housing and the delays in the land grant program were the main reasons why policy outcomes did not provide housing for the poor.

\section{Recommendations}

One of the most important issues that requires action is the provision of housing assistance to the poor. It is recommended first that the poor, eligible households bc identified, i.e., a poverty line be identified as a starting point. Possibilities for housing the poor could include utilizing part of the existing public housing projects and/or earmarked cash transfers.

Another recommendation is that a decision about the public housing units should be reached as soon as possible. One possible solution is to auction the units in the open market. Another possible solution is to allocate the units to government agencies for employee housing.

Regarding home finance, it is recommended that a wider scope of financing instruments be considered. This would 
provide an incentive for maintaining the existing housing stock as well as being a potential source of capital growth of the RDEF.

The clear assignment of responsibilities to different public sector institutions involved with housing is recommended. This measure would lessen bureaucratic inertia involved with decision-making and it would also allow for easier evaluations of progress and achievements.

It is recommended that demand support policies be given greater consideration. A greater reliance on private sector activity appears favorable due to that sector's demonstrated effectiveness, as well as its being more in conformity with the traditional norms of the country.

A long run perspective of housing should consider the need for additional and more affordable units as well as the potential effect of cyclical downturns in the economy, which could have very negative effects on housing and other linked markets.

Finally, the thesis brings to attention the reed for additional and better information on the number, condition, tenure, and type of housing within the Kingdom. The general nature of the thesis will hopefully inspire additional research and study in the areas that are addressed. Specific areas include an empirical investigation of housing supply responsiveness, applicability of long term mortgage instruments to the 
Islamic setting, the establishment of applicable housing codes, and the appropriate institutional structure for allocating and managing public housing projects. 


\section{BIBLIOGRAPHY}

Aaron, H., "Policy Implications: A Progress Report," in Do Housing Allowances Work?, Bradbury, K. and Downs A., (eds.) Brookings Institution, Washington, D.C., 1981.

Aaron H., Shelter and Subsidies: Who Benefits from Federal Housing Policies?, Brookings Institution, Washington, D.C., 1972 .

Abrams, C., Man's Struggle For Shelter in an Urbanizing World, MIT Press, Cambridge, Mass, 1964 .

Al Benaa, "llousing in the Arab World," Architecture Magazine, lst year, $4 \mathrm{th}$ issue, 1979.

Al Khatib, F., "Saudi Arabia: An Estimation of the Demand for Housing in Riyadh," paper presented to The International Conference for Cooperation Among World Cities, Caracas, Venezuela, October, 1982 .

A1 Sadr, M.. Itkisadouna, Dar A1 Kitab A1 Lubnani, Beirut, 1977 (in Arabic).

Allen, G., J. ritts, \& E. Glatt, "The Experimental Housing Program," in Bradbury, K., and Downs, A., (eds.), Do Housing Allowances Work?, Brookings Institution, Washington, D.C., İg8

Barnett, C.I.., "Expected and Actual Effects of Housing Allowances on inusing Prices," RAND, Santa Monica, 1979.

Bourne, L., The Geography of Housing, John Wiley, New York, 1981 .

Eradbury, K. and A. Downs (eds.) Do Housing Allowances Work?, Brookings Institution, Washington, D.C., 1981 .

Carlson, B., and D. Heinberg, How Housing Allowances Work: Integrated Findings from the Experimental Housing Allowance Program, Washington, D.C., Urban Institute, 1978. 
Chupra, M., "The Islamic Welfare State and its Role in the Economy," in Studies in Islamic Economics by $K$. Ahmad (ed.), the Is lamic Foundation, London, 1980 .

Davis, 0 . and A. Whinston, "The Economics of Urban Renewal," Law and Contemporary Problems, XXVI。 $5: 105-117,1966$.

DeLeeuw, F. and K. Ekanem, "The Supply of Rental Housing," American Economic Review, Vol. 61, No. 5, December 1971 .

Department of Housing and Urban Development (Hiv), Housing and Urban Development in Saudi Arabia, International Country Profile, Government Printing Office, Washington, D.C., 1977.

DeQuin, H., The Challenge of Saudi Arabia, Eurasia Press, Singapore, 1976 .

Downs, A., "Housing the Urban Poor: The Economics of Various Strategies," American Economic Reyiek, Vo1. 59, Seprember, 1969 .

Drakakis, D. and Smith, Urbanization, Housing, and the Development Process, St. Martin's, New York, 1980 .

Farahat, A. and N. Cebeci, "A Housing Project: Intentions, Realities, and Alternatives," in Serageldin, I. and El-Sadek, S. (eds.) The Arab City, Arlington, Virginia, 1982 .

Fischer, C., M. Baldassare, and R. Ofshe, "Crowding Studies and Urban Life: A Critical Review," Journal of the American Institute of Planners, November 1975, pp. 406-418.

Grebler, L. and L. Burns, The Housing of Nations, Macmillan, London, 1977.

Grieson, R., "The Supply of Rental Housing: Comment," American Economic Review, 1973, pp 433-36.

Grigsby, W. and L. Rosenberg, Urban Housing Policy, APS Publishers, New York, 1975.

Grimes, 0., Housing for Low Income Urban Families, The

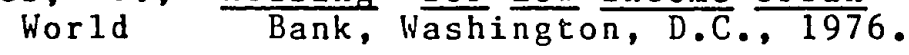


Hansen, N., "Criteria For a Growth Center Policy," in Freidmann, $J$, and $W$. Alonso, Regional Policy: Readings in Theory and Applications, MIT Press, Cambridge, Massachusetts, 1975.

Heilbrun, J., Urban Economics and Public Policy (2nd Edition), st. Martin's Press, New York, 1981.

Hendershot, P. and K. Villani, "The Federally Sponsored Credit Agencies: Thair Behayior and Impact," in Buckley, Tuccillo, and Villani, (eds.), Capital Markets and the Housing Sector: Perspectives on Financial Reform, Ballinger, Cambridge, Massachusetts, 1977 .

Institutional Investor, November 1982 issue.

Kadi, 0. and H. Ibrahim City Planning in Saudi Arabia, Riyadh, 1981. (in Arabic).

Kanoo, A., "A Study of the Need For Housing and the Development of a Housing System for Saudi Arabia and the Arabian Gulf," Ph.D. Dissertation, University of Texas at Austin, 1971.

Kasl, S., "Effects of Housing on Mental and Physical Health," in Housing in the Seventies: Working Papers(1), Washington, D.C., U.S. Government Printing office, 1976.

Kasl, S., "The Effects of the Residential Environment on Health and Behavior: a Review," in Hinkle, L. and Loring, W., The Effect of the Man Made Environment in Health and Behavior, Housing Education and Welfare (HEW) At Ianta, 1977.

King Abdul Aziz University, Saudi Regulations Bulletin, Okaz Press, Jeddah, (in Arabic), $1979,1980$.

Linn, J, Cities in the Developing Wor1d, Oxford University Press, New York, 1983 .

Mandaville, J.E., "Usurious Piety: The Cash Waqf
Controversy in the Ottoman Empire," International
Journal of Middle East Studies, 10, 1979.
Marcuse, P., "Housing Policy and the Myth of the Benevolent
State," in Housing
Perspectives, Bobbs-Merrill Co., Indiana, 1979.

Meeks, C., Housing, Prentice-Ha11, New Jersey, 1980. 
Mills, E., "Economic Analysis of Land Use Controls," in Mieskowski, P. and Strazheim, M. (eds.) Current Issues in Urban Economics, Johns Hopkins University Press, Baltimore, 1979 .

Mills, E. and A. Sullivan, "Market Effects," in Do Housing Allowances Work? Bradbury $K$. and Downs A. (eds.), Brookings Institution, Washington, D.C., 1981.

Ministry of Finance and National Economy, The Banking Control Law, Government Press, Riyadh, $197 \overline{8 .}$

Ministry of Finance and National Economy, Cost of Living Index: $\frac{\text { All }}{\text { Populations, }}$ Cities and $\frac{\text { Middle }}{\text { Central }}$ Depome $\frac{\text { Incout }}{\text { Saudi }}$ Populations,

Ministry of Finance and National Economy, Statistical Yearbook, Fifteenth Issue, Central Department of Statistics, Riyadh, 1979.

Ministry of Finance and National Economy, Statistical Yearbook, Seventeenth Issue, Central Department of Statistics, Riyadh, 1981.

Ministry of Planning, Achievements of the First and Second Development Plans, Ministry of Planning, Riyadh, 1982 .

Ministry of Planning, Kingdom of Saudi Arabia: Second Development Plan 1975-80 A.D., Ministry of Planning Press, Riyadh.

Ministry of Planning, Kingdom of Saudi Arabia: Third Development Plan, 1980-85 A.D., Ministry of Planning Press, Riyadh, 1980.

Mishan, E., Introduction to Normative Economics, Oxford University Press, New York, 1981.

Mitchel1, R., "Some Social Implication of High Density Housing," American Sociologial Review, (36), 1971.

Montgomery, R. and D. Mendelker, Housing In America, BobbsMerrill Co., New York, 1979.

Mubarak, M., "State Economic Intervention in Islam," in The Islamic Economics, International Center for Research in Islamic Economics, Jeddah, 1980 (in Arabic). 
Musgrave, R., "Policies of Housing Support: Rationales and Instruments," in Housing in the Seventies: Working Papers(1), Washington, D..C., U.S. Government Printing Office, 1976.

Muth, R., "The Demand for Non-Farm Housing," in A.C. Harberger (ed.), The Demand for Durable Goods, University of Chicago Press, Chicago, 1960.

Muth, R., "The Rationale for Government Intervention in Housing," in Housing in the Seventies: Working Papers $(1)$, U.S. Government Printing Office, Washington, D.C. 1976.

National Commission on Urban Problems, Building the American City, Washington, D.C.: U.S. Governinent Printing office, 1968.

Nevitt, A., "Housing in a Welfare State," UEL Vol. $14: 1980$, pP. 33-40.

Newman, 0., Defensible Space, Macmillan, New York, 1972.

Nourse, H., "A Rationale for Government Intervention in Housing," in Housing in the Seventies: Working Papers (1), Washington, D.C., U.S. Government Printing office, $\quad 1976$.

Nyrop, R., Area Handbook for Saudi Arabia, U.S. Government Printing Office, Washington, D。C. 1977.

Olsen, E., "A Possible Rationale for Government Intervention in Housing: The Slow Adjustment of Housing Market to its Long Run Equilibrium Position," in Housing in the Seventies: Working Papers (1), Washington, D.C., U.S. Government Printing Office, 1976.

Ozanne, L. and R. Struyk, "The Price Elasticity of Supply of Housing Services," in L. Bourne and R. Hitchcock (eds.), Urban Housing Markets, University of Toronto Press, Toronto, 1977.

Quigley, J., "What Have We Learned About Urban Housing Markets," in P. Mieskowski, and M. Strazheim, (eds.), Current Issues in Urban Economics, Johns Hopkins University Press, Baltimore, 1979.

Quigley, J., "Housing Allowances and Demand Oriented Housing" in R. Montgomery and D. Marshall (eds.), Housing Policy for the 1980s, Lexington Books, Lexington, 1980 . 
Qutub, S., Social Justice in Islam, Dar Al Shoorouq, Cairo, 1982 (in Arabic).

Rawls, J., A Theory of Justice, Harvard University, Cambridge, 1971 .

Rea1 Estate Development Fund, Seven Year Review, 1395/961401/92, Saudi Media Systems, Riyadh, Saudi Arabia, 1983 .

Rothenberg, J., "A Rationale for Government Intervention in Housing: The Externalities Generated by Good Housing," in Ilousing in the Seventies: Working Papers (1), U.S. Government Printing office, Washington, D.C., 1976.

Ryde11, C., "Shortrun Response of Housing Markets to Demand Shifts," The Rand Corporation, Santa Monica, 1979.

Rydel1, C.P., Supply Response to the Housing Allowance Program, The Rand Corporation, 1980 .

Saqr, M., "Islamic Economics: Understandings and Basis," in Islamic Economics, selected research from First International Conference on Islamic Economics, King Abdul Aziz University, Jeddah, Saudi Arabia, 1980 (in Arabic).

Saudi Arabian Monetary Agency, Annual Report 1401 (1981). Saudi Arabian Printing Company, Ltd., Ammariyah, Riyadh.

Saudi Arabian Real Estate Co., Board of Directors Report, Riyadh, 1982.

SCET International, Survey of Constraints to the Implementation of the Saudi Arabian Second Plan, Housing Ministry of Planning document, December 1975.

Schoor, A., Slums and Social Insecurity, U.S. HEW, Washington, D.C. $1 \overline{966 .}$

Sert Jackson International/Saud Consult. Jeddah Action Master Plans, Report Number 5, SOcio Economic Data, prepared for Ministry of Municipal and Rural Affairs, 1399 A.H. (1979 A.D.).

Sert Jackson International, Jeddah Action Master Plans, Report Number 8, Land Development Policy, 1980. 
Siddiqi, M., "Muslim Economic Thinking: A Survey of Contemporary Literature," in Khurshid Ahmed (ed.), Studies in Islamic Economics, The Islamic Foundation, Leicester, U.K., 1980.

Singapore Housing Development Board, Annual Report, 198182, Housing Development Board, Republic of Singapore, 1983 .

Smith, D.D., Urbanization, Housing, and the Development Process, St. Martin's Press, New York, 1980 .

Solomon, A.P., Housing the Urban Poor, MIT Press, Cambridge, $\frac{\text { Housing }}{1974 .}$

Strassman, W.P. The Construction Sector in Economic Development," Scottish Journal of Political Economy, $17,1970$.

U.S. Library of Congress Processing Dept., Bulletin 1, June 1945, Washington.

Varady, D., "Indirect Benefits of Subsidized Housing Programs," in Journal of the American Planning Association, Vol, $\frac{\text { 48, No. }}{4,} 1 \frac{1982}{\text {. }}$

Vaughan, R., "The Impacts of Federal Policies on Urban Economic Development," in Solomon, A. (ed.) The Prospective City, MIT Press, Cambridge Massachusetts, 1980.

Weicher, J.. Housing: Federal Policies and Programs, A.E.I., Washington, D.C., 1980 .

Weicher, J., "The Rationales for Government Intervention in Housing: An Overview," in Housing in the Seventies: Working Papers (1), U.S. Government Printing Office, 1976.

Weicher, J.C., "Urban llousing Policy," in Mieskowski, P. and M. Strazheim (eds.). Current Issues in Urban Economics, Johns Hopkins University Press, Baltimore, 1979.

Zarqa, M.. "Islamic Economics: An Approach to Human Welfare," in Studies in Islamic Economics, Yhisshid, Ahmad (ed.), The Islamic Foundation, Leicester, U.K., 1980 . 
Interviews

June 1982 to March 1983

o His Excellency (H.E.) Deputy Minister of Housing, Riyadh

- H.E. Regional Director of Ministry of Planning, Jeddah

- H.E. Regional Director of Ministry of Housing Projects/Jeddah

- V.P. Planning, Jaudi Real Estate Co., Riyadh

- Chairman of the Board, Saudi Real Estate Co., Riyadh

- Director General, Real Estate Development Fund, Riyadh

o H.E. Deputy Minister of Planning and National Economy, Riyadh

o V.P. National Commercial Bank, Jeddah

o V.P. Saudi. Investment and Banking Company, Jeddah

o H.E. Deputy Municipality Director, Jeddah

- Representative, Al Faisaliah Charitable Organization, Jeddah

- Regional Director of the Ministry of Endowments and Pilgrimage, Jeddah

- Manager of Bin Mahfouz Endowment Buildings, Jeddah

- Manager of the Prince Fawaz Cooperative Housing Project, Jeddah

- Office Manager for the Deputy Minister for Administrative Affairs, Ministry of Finance and National Economy, Riyadh

o Director of the Department of Information and Followup, Ministry of Planning

- Director of the Research Section, Ministry of Planning 
- Engineer in Charge of Low Income Land Grants, Jeddah Municipality, Jeddah

- Planning Officials, Sert Jackson International Ltd., Jeddah

- Engineer, A1 Mabani Construction Company, Jeddah

- Project Manager, F.A.S.T., Prefabricated Homes Construction, Jeddah

Notes:

(1) Some interviewees, not listed above, expressed wishes for anonymity.

(2) Site visits were conducted to public housing projects in both Jeddah and Rigadh.

(3) Site visits tc Endowment Housing were limited to the city of Jeddah. 